\title{
UC-NRLF
}

B 3 드미르 
BIQLOGY. LHBRARY UCB

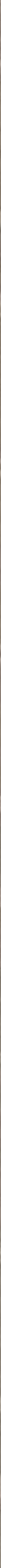




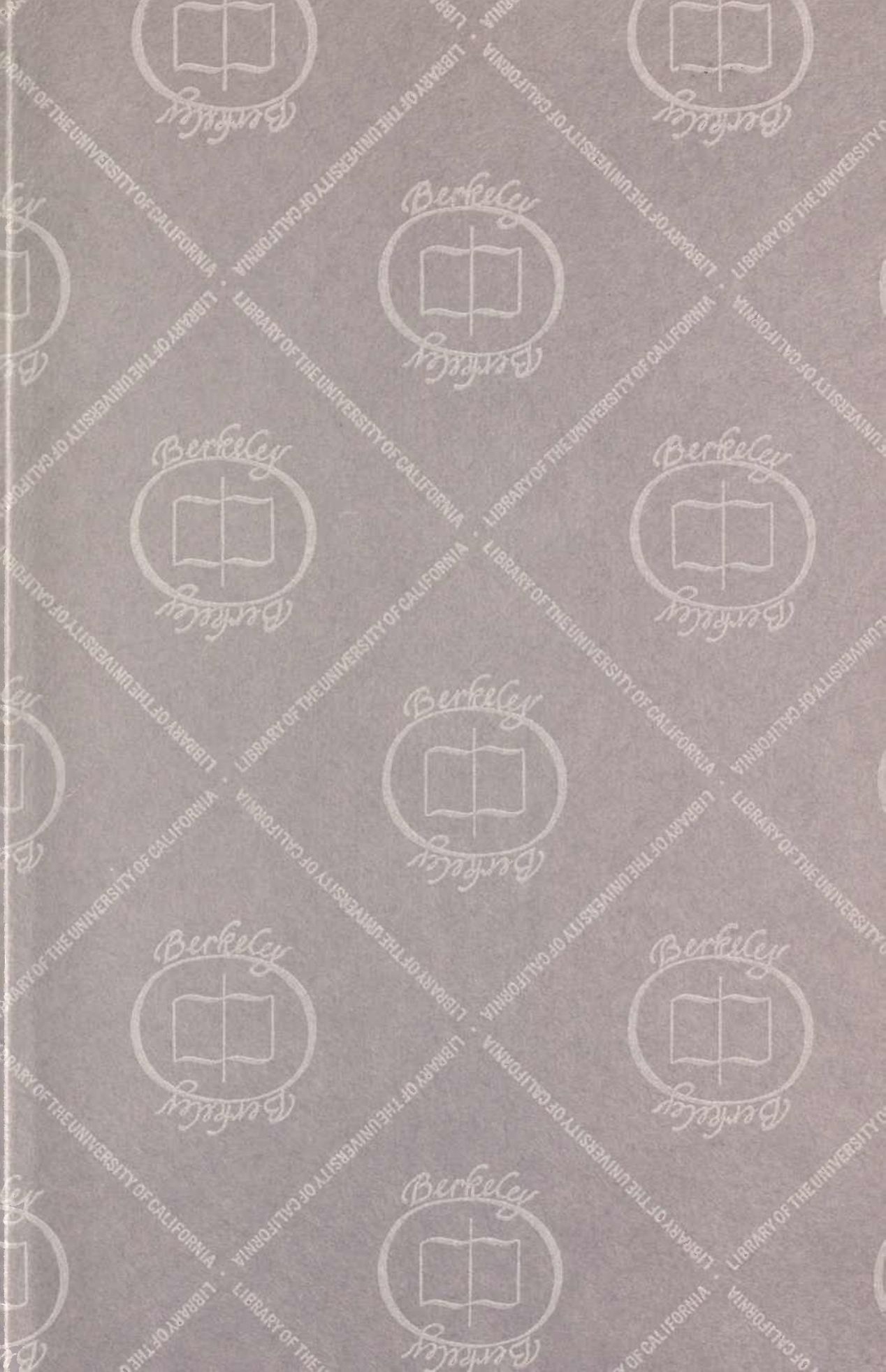


BI

\%.

30

6

$33^{\circ}$

38 




\section{A FIELD AND LABORATORY GUIDE IN BIOLOGICAL NATURE-STUDY}

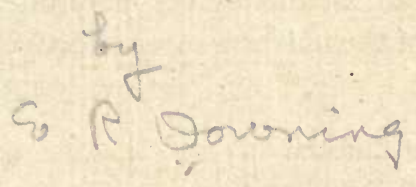




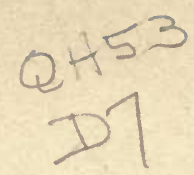

\section{PREFACE}

This field and laboratory guide in biological nature-study is the outcome of many years' experience in preparing teachers to handle nature-study in the grades and biology in the secondary schools. It is intended primarily for the use of students who are preparing to teach this work and of teachers who are already at it. It does not attempt systematically to cover the field of biology but merely to deal with those groups of plants and animals that are of most interest to pupils.

Those phases of the subject-matter have been selected that lend themselves best to project and problem teaching, that develop appreciation of the commonplace environment, and that make for social efficiency on the part of the pupil. It is hoped that the book will prove helpful to that large and increasing group of teachers, both actual and prospective, who are earnestly trying to use in the schools that scientific method and accumulated knowledge so important in modern life. Further, it is hoped that through the teachers it will serve those boys and girls who, by acquaintance with nature, will come to adjust themselves more intelligently to their environment, use the forces of the universe more effectively, and be happier in their enlarged outlook.

The University of Chicago

ElLiot R. Downing

The School of Education

October I, I9I8

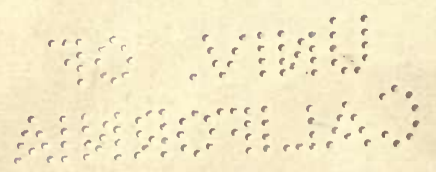




\section{CONTENTS}

INTRODUCTION

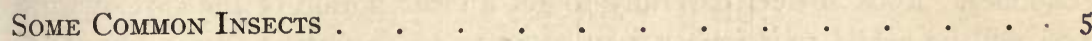

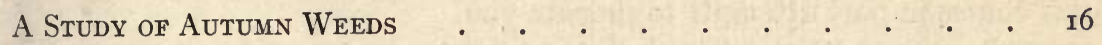

Key to the Common Weeds of the Chicago Region $\ldots \quad \ldots \quad \ldots \quad$ i 7

Animals of Pond and Stream • • • . . . . . . . 30

TREes • • . . . . . . . . . . . . . 38

Key to Trees of the Chicago Region • • • • • • • 42

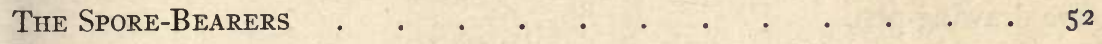

Antmal Compantons . . . . . . . . . . . . . ${ }_{56}^{6}$

BIRD-STUDY . . . . . . . . . . . . . 67

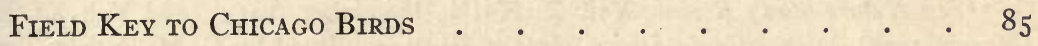

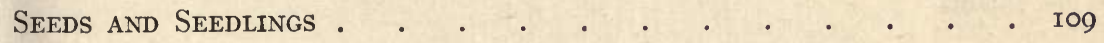

The Garden • • • • • • • • • • • • • • • II6 


\section{INTRODUCTION}

Secure a copy of the outline of the course in natural science in the Elementary School of the University of Chicago ${ }^{\mathrm{I}}$ (or similar outline for other schools $^{2}$ ). Look it over carefully to get a clear notion of the sort of work you will be asked to do when you come to teach nature-study, for which this course in part attempts to prepare you.

Follow carefully the directions for collecting and studying the materials suggested in the outlines. It is more important that you should acquire correct methods of studying nature material and the point of view of the self-reliant investigator than that you amass information. Answer all questions asked and make all drawings and diagrams indicated in the notes on the blank pages opposite the directions. Notes and diagrams are to be in ink. Use Higgins' waterproof ink for the drawings, making them with a fine drawing-pen.

'Published in the Elementary School Journal, Vol. XVIII (February, March, and April, I9I8); also reprinted under one cover and available at the School of Education bookstore.

${ }^{2}$ See Nature-Study Review, Vol. X, No. 9 (December, I9r4), and Vol. XI, No. 3 (March, I9I5); also Illinois State Course of Study, published by C. M. Parker, Taylorville, Illinois. 




\section{SOME COMMON INSECTS}

Field trip.- On this trip take a couple of small boxes, a small bottle of gasoline, and an insect net. The two latter items will be furnished you; provide yourself with the boxes. Go out into a vacant lot, meadow, or border of the woods. Turn over old logs, stones, and boards; rip the bark off of stumps and capture any insects or other small animals encountered. Watch clusters of flowers for butterflies and bees, pond margins or marshy spots for dragon flies. Any of these insects except bees and wasps máy be picked up without danger, and these may be captured with a net; butterflies and dragon flies will also be so taken. Spill a few drops of gasoline on the abdomen of insects, spiders, etc., to kill them; then keep them in the box. Secure the following insects: a butterfly or good-sized moth, a dragon fly, a squash bug or a stinkbug, a beetle, a locust or a grasshopper, a bumblebee, a bluebottle fly or, better still, a horsefly. Spiders, thousand legs, and sow bugs also will probably be found. Kill them with the gasoline and bring in with the insects.

Obtain a couple of crickets and put them alive into the small bottle.

Insect cage.-Make an insect cage as follows: Fill a flowerpot four inches or more in diameter with earth. Plant in it a spray of sweet clover or other available plant. Set a lamp chimney into the earth over the plant and tie a piece of cloth over the top. The earth should of course be kept moist.

\section{The cricket.-}

Feeding the cricket.-Put the crickets into the insect cage. They will be quite at home in this cage and will live for many days. Cut a thin, wedge-shaped slice of apple and put it into the cage with the edge up. The crickets will probably mount this and proceed to eat. Notice that the cricket has several pairs of mouth parts, one pair of which is very horny and serves to crush the food; the other pairs are used to hold the food as it is eaten. These jaws are provided with little finger-shaped processes-jointed palps that serve the animal as feelers. How are these jaws moved as the cricket eats?

Parts of a cricket.- Notice on the head of the cricket the pair of long feelers, or antennae. Can you demonstrate how. these function? Touch one of the appendages at the end of a cricket's body and see if he is aware of it. Notice next the large eyes, each occupying a good share of the side 
of the head. These eyes are compound eyes; that is, they are made of a large number of simple eyes. Thrust your finger at the cricket without touching the antennae. Does he seem to see well ?

Movements.-Watch the cricket as he walks. How does he move his legs? Do the legs always move in the same order? Look carefully at the cricket's foot and notice of what parts it is made. Draw the foot. How do the hind legs differ from the other legs. How far can a cricket jump? See how many times its own length a grasshopper can jump. How far could a boy jump if he could leap as far in proportion to his length ? Study the hind leg of the grasshopper to see if you can discover what appliances and arrangement of parts there are that enable him to jump so well. What advantage is it to a cricket or grasshopper to be able to jump? When you pick up a grasshopper by its hind leg what often happens? Would this be of any value to the insect?

Cricket music.-The cricket is perhaps better known by his music than by his appearance. Undoubtedly the crickets will sing while they are confined in their cages. Observe how this is accomplished. Do both male and female crickets chirp? Can you think what possible end the chirp serves? How can you tell the male and female apart? See the ear, an oval disk, on the first leg of the animal.

Breathing.-Observe a cricket or grasshopper carefully and see that the abdomen is made up of a number of rings, each telescoped into the one ahead of it. These rings are held together by delicate membranes which cannot ordinarily be seen but which are evident when the abdomen of the locust is extended in the egg-laying process. Watch the abdomen carefully and observe that it is constantly expanding and contracting, bellows-like. In fact, this is the way in which air is drawn into the body. These insects do not breathe through their mouths; they do not have any noses, but the air is taken in through several little pores that can readily be found on a grasshopper's abdomen, one on each side of nearly every ring. Draw the abdomen to show these.

Egg-laying.-Watch beside the sidewalks for a grasshopper laying its eggs. In the autumn you will find the female with the abdomen thrust deep into the ground, the insect looking as if the abdomen had been cut off. Make a sketch of the position assumed by the insect, then'lift the animal up so as to pull the abdomen out of the ground. Note how long the abdomen is. Dig up the soil at this spot and see if you can find the cluster of eggs. Normally they remain in the ground until the following spring, when they hatch into young locusts, or grasshoppers, as we commonly call them.

Plagues of locusts have been among the notorious insect phenomena in the history of the world. The western states have many times suffered 


from invasion of the Rocky Mountain locust, and the locusts of the Old World have frequently invaded civilized communities and have played havoc with growing crops. Read the article, "Jerusalem's Locust Plague," in the National Geographic Magazine (Vol. 28, p. 51 I, December, I9I5).

Insect collection. - If an insect collection is to be made each pupil should provide himself with an insect net, bicycle oil can full of gasoline, a deep cigar box, a sheet of cork, and insect pins.

Insect net.-To make the net frame use an old broomstick or a twofoot length of bamboo for a handle and a forty-inch length of stiff wire for the hoop. Bend the wire so that the ends will cross each other six inches from their tips; twist these crossed wires about each other two or three times. Now bend the ends so they will lie on opposite sides of one end of the handle and with fine wire or strong cord bind the net frame securely to the handle. If preferred, the wire frame may be soldered to a brass ferrule made to fit onto a jointed handle. The net is best made of coarse bobinet,

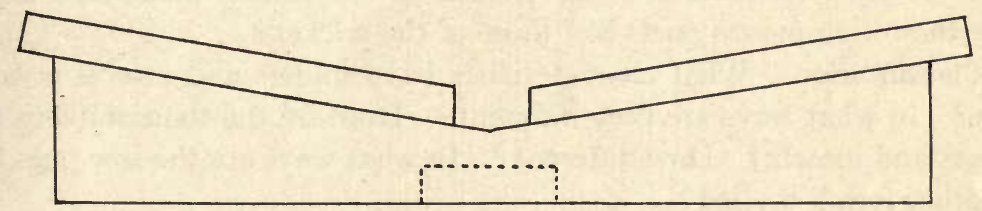

FIG. I.-Diagram of the spreading-board

although cheesecloth or fine-meshed mosquito netting will do. It should be about eighteen inches deep and large enough around to fit the hoop. Sew it onto the wire frame and then bind a strip of cloth over the wire to prevent wear.

Box.- Glue sheet cork to the bottom of the cigar box in which the insects are to be kept, stuck on pins set into the cork. Insects, like bugs and flies, may be pinned by running an insect pin of appropriate size through the thorax; beetles, by sticking the pin through the right wing cover. Dragon flies, moths, butterflies, etc., must be spread so that the wings will remain expanded.

Spreading-board.-For spreading the wings a spreading-board is a necessity. Take two soft-pine boards a foot or more long and three or four inches wide. Cut two strips as shown in the diagram (Fig. I). Then fasten the boards to these ends so they will incline toward each other and have a groove between them. Underneath this groove fasten another strip of pine or cork. Run the pin through the thorax of the animal and stick its point into this lower strip of cork or pine, the body of the insect in the groove of the spreading-board. Fasten the wings on the boards by means 
of strips of paper pinned across them. Do not run pins through the wings. The rule adopted by collectors is to fasten the wings so that the hind margins of the fore wings will make a straight line which is at right angles to the long axis of the insect's body. After the insect has been on the spreading-board and dried for several days it may be put into the insect box. While the insect is on the board the board should be kept in a drawer or cupboard away from mice and insect pests.

What is an insect? - Compare the dragon fly, squash bug, beetle, locust, bumblebee, fly, and butterfly. These are all insects. What characteristics have they in common? What, then, is an insect? How many of them have a hard and slippery coat-of-mail? Would such be particularly serviceable?

Adaptation of mouth parts. - Note the sharp sucking-tube of the squash bug, the coiled sucking-tube of the butterfly. The latter may be unrolled with a pin. How do these two insects feed? Draw the head of the latter insect to show its sucking-tube. Which of the insects mentioned above have the biting mouth parts like those of the cricket?

Classification.-What characteristics have spiders and insects in common? In what ways are they different? How are the thousand-legs like spiders and insects? How different? In what ways are the sow bugs like the other forms studied?

Such differences and resemblances are the basis of the classification of animals and plants. All the animals here studied belong to one group, the subkingdom Arthropoda. What are the characteristics of the arthropod type?

- The animal kingdom is divided into subkingdoms like the vertebrates, molluscs, arthropods, etc. The latter group is subdivided into four classes. What are they? Give example of each.

Classes are divided into orders. Fill in the following:

The beetles belong to the order

Butterflies and moths belong to the order

Flies belong to the order

Ants, bees, and wasps belong to the order

Bugs belong to the order

Crickets and grasshoppers belong to the order

Dragon flies belong to the order 


Orders are again divided into families, those insects with family resemblances being classed together. Thus the crickets belong to the family Gryllidae. Families are split up into genera and each genus into species. The animals that are practically identical all go to make up one species. Thus all tiger swallowtail butterflies belong to the species Turnus, all swallowtails to the genus Papilio. The scientific name of an animal or plant is made up of the name of its genus and species, so Papilio turnus is the scientific name of the tiger swallowtail.

Butterflies.- See specimens of the following butterflies and moths in the cases of the school museum or look them up in Holland's Butterfly Book and Moth Book. Learn to know them so you can recognize them in the field: monarch, royal fritillary, great spangled fritillary, Baltimore, checker spot, question-sign anglewing, comma anglewing, mourning cloak, red admiral, painted lady, Hunter's butterfly, red-spotted purple, viceroy, little wood satyr, common wood nymph, great copper, bluet, common white cabbage butterfly, dog's-head, sulphur, pawpaw swallowtail, tiger swallowtail, spicebush swallowtail, pipevine swallowtail, eastern swallowtail, giant swallowtail, and silver-spotted skipper.

Life-history of the butterfly. - In the late spring and in the summer material for the study of the life-history of the butterfly is easily found. Look over cabbage plants for eggs, larvae, and chrysalids of the cabbage butterfly. The adults will be found flying over the cabbage patch. Look on milkweed for the eggs, larvae, and pupae of the milkweed butterfly. Draw the eggs on the leaf, the larva, and the chrysalis. Keep the larva of some butterfly in the insect cage with its food plant until it pupates. See this process if possible. A few days later the chrysalis will open and the butterfly will emerge, expand its wings, and be ready to fly. Watch this also.

Moths.-The following moths are common and should be known: Cecropia, polyphemus promethea, luna, eight-spotted forester, imperial, royal, bumblebee moth, tomato hawk moth, Isabella, Io, cutworm moth, tussock moth, silkworm moth, and clothes moth.

Moth larvae.-Look for the larvae of the moths. The larva of the tomato hawk moth (a big green "worm") is common on tomato plants. Cecropia larvae ornamented with blue, orange, and red knobs are easily located on willow twigs. The brown, woolly bear, a very common caterpillar, is the larva of the Isabella moth. The tussock larvae are common on elm trees. Put any of these in the insect cage together with sprays of the food plant stuck into the moist soil. Supply more of the food plant as the supply is eaten. How would you tell one of these "worms" (that are really insect larvae) from a true worm, like an earthworm? How does the animal 
crawl? How does it eat? Where does it come from? The Cecropia larva, when full grown, spins a silken cocoon in which the chrysalis remains during the winter. Look for such cocoons, not only of the Cecropia but of other moths. Collect several for study (see directions, below). The tomato hawk moth larva burrows into the gound, transforms to its chrysalis, and the chrysalis remains there until the moth comes out of it the following spring. After the larva has disappeared in the soil of the pot leave it a few days before digging up the pupa.

The leaves of the following plants are the food of many larvae; look over such plants to secure specimens which can be reared. Basswood, butternut, cherry, hickory, pawpaw, poplar, sassafras, walnut, willow, grape, carrot, parsley, everlasting, thistle, and violet.

The silkworm.- One of the most interesting moths, because of its economic value, is the one that gives us our silk. Send fifty cents to the Kny-Scheerer Co., 4Io W. Twenty-seventh Street, New York City, for a batch of silkworm eggs. They will come on a small piece of card which may be put in a covered tumbler with a few fresh mulberry leaves. The eggs will hatch in a few days and the tiny larvae will crawl onto the leaves to feed. Add fresh leaves as necessary and as the larvae grow transfer them to an insect cage where more sprays of leaves may be kept. Keep record of the length of a newly hatched larva and of its length on successive days as it feeds. The full-grown larvae will spin their cocoons. How do they do it? Is the silk thread continuous? How long is it before the moth hatches after the cocoon is complete? Mating and egg-laying follow, and the eggs will start the cycle again.

Study of the Cecropia cocoon.-The Cecropia is known as the American silkworm. Note and draw shape of cocoon. Cut it open carefully so as not to injure the contained pupa. Is the silken covering tough? Is there variation in the thickness of the silken covering? (Compare yours with your neighbors'.) Can you see in the pupa the eyes, legs, antennae, abdominal segments? What advantage is the cocoon to the animal? Draw the pupa. In the spring the pupa transforms to the moth and comes out of the cocoon. Watch the process either in this or some other moth. Let the moth, limp and bedraggled as it comes out, crawl up on some support like the wire sides of the large insect cage and expand its wings. Watch it to see how this is accomplished.

Parasitism.- You will be quite sure to find that some of the Cecropia cocoons are full of small silken cocoons instead of the usual pupa. These cocoons will develop into ichneumon flies that lay their eggs in the larvae of Cecropia. The young feed on the blood and later on the internal organs, killing the animal but often not until it has spun its cocoon. If opportunity 


occurs, watch in the spring and early summer the great ichneumon, Thalessa, depositing its eggs in the larvae of wood-boring beetles. At least see the specimen of this insect in the museum, noting the very long ovipositor, and read "The Bewitched Cocoons" and "The Most Marvellous Drill in the World" in William Hamilton Gibson's Sharp Eyes.

\section{Ants - a study of an animal community.-}

Directions for making nest.-Cut a piece of glass 4 by 5 inches or any convenient size, or use for the foundation of the nest an old 4 by 5 negative. The gelatin film can be cleaned off the negative if the latter is soaked in water for a little while. Cut some glass strips one-half inch wide from any old window glass. It is best to use glass of single thickness and to use window glass rather than picture glass, since the former is softer and less difficult to cut. To cut glass secure a wheel glass-cutter from the hardware store, for five or ten cents. Lay a ruler on the glass a little to the left of the line along which the cut is to be made and, holding the glass-cutter as you would a pencil in writing, draw it along the glass beside the ruler, using just enough pressure to make the wheel cutter "bite" the glass. You can tell this best by the noise. Any school child can cut window glass, for no great strength is needed. When the scratch is made place the thumbs on top of the glass near the edge on opposite sides of the scratch and press upward with the bent first fingers held below the glass.

The walls.-Fasten the half-inch strips along the edges of the foundation glass with ordinary glue, laying the strips flat, i.e., with the broad side down. Leave a half-inch opening at one corner for a door. Cement a second strip on top of each first strip, so as to make this glass wall two thicknesses of glass high, in order to allow enough space for the ants to move around freely inside the nest. With strips of glass divide the nest into two rooms, leaving a space between this partition wall and the outer wall to serve as a door. Cut some black cambric or calico into strips an inch wide and glue it to the edge of the nest all the way around, letting it lap over on the top of the wall and on the under side of the foundation glass. This makes an opaque covering for the wall of the nest, like a passe-partout binding.

Ventilation.-Cut some strips of Turkish toweling an inch wide. Turn in the edges of this toweling so that they meet, thus making a half-inch strip that is double. Now cement these turned-in edges to the top of the half-inch strips that form the walls of the nest. Cut pieces of glass of proper size to cover each room of the nest and lay them on the Turkish toweling for a roof. The toweling admits enough air to ventilate the rooms. Since ants are accustomed to live in the dark, pieces of cardboard should be cut the same size as the glass covers for each room and laid over the nest. 
When the nest is in use, keep the parts in place by drawing a rubber band around them. When the nest is lying on the table, light is excluded from the under side by the table, from the edges by the black binding, and from above by the pieces of cardboard. Cut a thin slice of sponge and place in the inner room. The nests should stand a few days to dry out, as the odor of glue is not an agreeable one even to ants.

Directions for stocking and caring for the ants' nest.-Take a pint fruit jar with its cover and go out to where ants are abundant. Dig up an ants' nest or break to pieces an old log or stump in which are found the galleries of the large black carpenter ant. Look for the eggs, larvae, or pupae. The eggs are tiny white grains, the larvae look much like rice grains, while the pupae look like puffed rice grains. Scoop these up with the ants and dump them into the pint jar; more or less dirt and débris will be taken up at the same time. Cover and bring the material back to the schoolroom. Set the completed ants' nest on the bottom of a large shallow tin pan; see that the sponge in it is moist. Set this pan in a still larger one partly filled with water. The inner pan must at no point touch the rim of the outer. Dump the material brought in from the field down beside the nest. As the débris dries out the ants will take their eggs, larvae, and pupae into the nest. When this is accomplished plug the front door of the nest with a wad of absorbent cotton. The nest may now be taken out and kept on the table for observation.

Feeding the ants and cleaning the nest.-A bit of peanut the size of the head of a pin or a bit of sponge cake dipped in honey may be put into the nest once a week. A shred of raw meat may occasionally be given the ants. Uneaten remnants of the food should be removed within twenty-four hours. To clean the nest remove the cardboard cover from one room. The ants will take their material all into the dark room. Then plug the door between the two rooms and wipe out the vacant room with a cloth moistened in alcohol. Let the room stand open for five or ten minutes, until the alcohol fumes have disappeared. Remove the plug from the door, cover this room, and uncover the other. Then the process may be repeated in the second room.

Habits.-Watch the ants you have to see how they busy themselves. Can you distinguish queen, drones, and workers? Are there soldier ants present? Which members of the community feed the larvae or young ants? Do the ants of the community seem to communicate with each other? If so, how? Do they feed each other? How does the ant clean itself? Watch the nests of ants out of doors to see what the animals are doing. Among other things you will find that the ants whose nests are in the sand will be busy bringing grains of sand out of the nests and carrying 


sand grains in again. Can you explain this apparently foolish process? In the late summer and early fall you will find a great many winged ants coming out of the nests. These are mostly males getting ready for the nuptial flight. Find out what the nuptial flight is and the events that happen at this time.

Aphids.-Look for plant lice on the succulent fall weeds, or on the plants in the garden. You will find most of them with their sucking-tubes imbedded in the tissue of the plant from which they are drawing their food. Some of them may be the winged males and females. You will often find ants visiting these colonies of aphids. Watch the ants to see what they do to the aphids. Read Bulletin $I 3 I$ of the University of Illinois Agriculture Experiment Station on the "Behaviour and Habits of the Cornfield Ants." Read also W. M. Wheeler's Ants (pp. 267-93 and 318-36). Look up the facts in regard to the rate of reproduction in the plant lice.

Wasps.-If possible find in the woods or around the barn nests of the paper wasps, or under the eaves of the house, barn, or outbuildings the clay nests of the mud-dauber wasps. Watch the wasps to learn as much as possible of their habits. Procure some old nests of either the paper wasps or the mud dauber and examine their method of construction. Can you make out the life-history of the animal?

Dragon fly.- Watch a dragon fly in its flight. Time it in seconds as it flies from one point to another. Measure the distance and see how many miles an hour it is going. Listen to the hum of a bee and devise a way to tell how many times it flaps its wings in a second. Observe on what the dragon fly feeds. Watch to see how many it eats in the course of a few minutes. What other names has a dragon fly? Are they justified by facts? Watch the dragon fly as it flies over stream or pond. Can you observe it in the act of depositing eggs? The young which hatch from these we shall study later. Draw the wing of the dragon fly. Weigh the wings and the rest of the animal separately. What is the relative weight of wings and body in a modern aëroplane? In what direction do most supporting veins run in the wing of the dragon fly? In what part of the wing are they? What is the advantage of this? Compare the bracing of the veins in this wing with the system of ribs and braces in an aëroplane wing.

Insect color.-Examine the wing of a butterfly under the low power of the microscope. Rub the wing with the finger and examine the rubbed spot again. What have you on your finger? With what are the wings covered? How are these arranged on the wings? Examine a spot of color. To what is it due? What is the color of the real grasshopper? the katydid? the locust? Where do the two former live? the latter? 
Was the cabbage-butterfly larva at all hard to find? What other larvae are green and what advantage does this color give them?

Are bees and wasps easy to find? What other animals that are abundantly able to care for themselves are also conspicuously colored? Is the tussock-moth larva brightly colored? Do birds eat it? Feed the brightly colored larvae of a milkweed butterfly to chickens. Will they eat it? Would you judge the milkweed butterfly to be palatable? What other larvae besides that of the tussock moth do you know to be hairy? Is there any evidence that these hairs are irritating to the skin?

Look at specimens of the walking-stick beetle in the school museum; of the anglewing butterfly on the dead leaves; and specimens of several moths on pieces of bark in cases to show protective colors. The redspotted purple and viceroy butterflies are closely related, both belonging to the same genus. The viceroy butterfly looks much like another common butterfly to which it is only distantly related. Which is this? Might this resemblance possibly profit the viceroy? Why is the bumblebee moth so named? Which animal profits by the resemblance? Of these several examples given which would you classify under protective coloration? warning coloration? mimicry?

House fly. - Obtain some manure, or some refuse from the kitchen and put an inch of this material in the bottom of a jelly tumbler. Capture several house flies and put them in the tumbler, covering the latter with a piece of cheesecloth held on by a string or rubber band. See if you can observe the flies laying their eggs. How many are laid? In a short time, probably, larvae will appear. Likely some of these will crawl down next to the glass when they pupate. How long is it before young flies appear? Fruit flies found in and about baskets of grapes or peaches may readily be bred if several are put in a test tube with a piece of fully ripe banana, plugging the top of the tube with a piece of absorbent cotton. The flies are small, but the stages in the life-history show plainly and they occupy little room. Locate in the block in which you live places where fly larvae or maggots are found. Any collection of decomposing matter is likely to contain them. Manure piles, garbage cans, lawn clippings, and garden refuse are likely places, and they may be found in heaps of rags, under bits of paper or oilcloth, or almost anywhere where the larvae can keep moist. On the opposite page draw a map of the block in which you live and show on it by red dots where you find the house fly breeding.

Rate of reproduction.- Look up data in regard to the rate of propagation of the fly. How many generations may there be in a single summer? How many eggs does the female lay? How long does it ordinarily take from the time the eggs are laid until the adult flies are grown? Starting 


with a single pair of flies in April, how many offspring will there be by fall, provided none die? Where do the flies that appear in the spring come from? Why is it especially difficult to keep flies out of the house in the fall? What are some of the best measures to take to exterminate the fly?

Make tabulations on the blank pages with the following headings and fill in information regarding the injurious and beneficial insects in so far as you can from your own knowledge or from books easily available in the library.

NAME OF INSECT

NAME OF INSECT

\section{INJURIOUS INSECTS}

WHAT IT INJURES

METHOD OF COMBATING

\section{BENEFICIAL INSECTS}

IN WHAT WAY IT IS BENEFICIAL

Spiders.-Locate a web of the large garden spider and capture an insect like the cricket or grasshopper. Throw it into the web. Observe what the spider does, and especially look to see how it spins the silk in which it wraps its prey. On the blank page opposite make a sketch of the web. What is the advantage of a web? Do you know of any other animal or plant traps found hereabout? If you can find a spider spinning its web observe how this is accomplished. Find somewhere about the house a cobweb. Do the strands have any definite arrangement? Find on the grass the web of the funnel weaver. Where does the spider stay in this web? Look under sticks and stones for wolf spiders. They are swift runners and the females will be found carrying the round silken egg case. On the ground and on tree trunks will be found some of the jumping spiders. How do they capture their prey? Look on the fall asters and sunflowers for specimens of the crab spider. Watch on the field trips for the young spiders sailing through the air on the tufts of their silk. 


\section{A STUDY OF AUTUMN WEEDS}

Making a collection.-Collect within a radius of four blocks of this building as many different kinds of weeds as you can. Obtain two specimens of each weed, six inches or so in length, to show shape of leaf, stem, characteristics of the blossom and fruit if possible. Number these weeds. At the same time collect samples of the seeds of the weeds, a thimbleful of each. Keep these in papers folded to hold them and numbered to correspond to the weeds. Dampen one set of the weeds collected and keep them in a box for identification later. Spread each specimen of the other set between the leaves of an old magazine with unglossed pages or between sheets of newspaper. Put them at once under a heavy weight to press. Change the paper at the end of twelve and again at the end of twenty-four

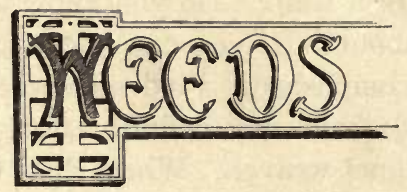

FIG. 2.-Sample cover decoration for Weed Book

hours so that they will dry rapidly, else the specimens will not retain their natural colors.

After they have been in press for ten days they may be mounted on sheets like the following. Mount one specimen on a sheet by touching tube glue to several points on the back of leaf, stem, and fruit, then laying it in the desired position on the sheet. After identification (see below) label each weed with its proper name, both common and scientific, and with the name of the family to which it belongs. Arrange the sheets on which the weeds are mounted in the order in which they occur in Gray's Manual of Botany. (You will find this in the library.) This will bring all weeds of the same family together. You will be expected to know at least fifty weeds and to have half that number in your collection. It will be wise to include in the collection the ones you find it most difficult to remember. There follows also a heavy paper cover for the weed book. Bind the weed mounts in it after you have printed the cover. You may make an attractive cover design either in black or color or simply print the words "Weed Book" upon it. (See illustration, Fig. 2.) 
Weed collection of Common name.

Scientific name.

Family 

Weed collection of . . . . . . . . . . . .

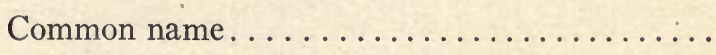

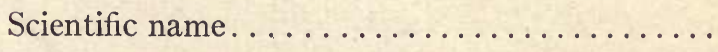

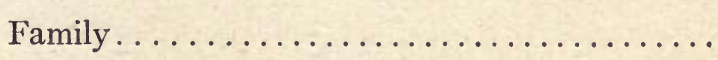



Weed collection of $\ldots \ldots \ldots \ldots \ldots \ldots \ldots \ldots$

Common name.......................

Scientific name.

Family ......................... 

Weed collection of . . . . . . . . . . . . . . . .

Common name......................

Scientific name......................

Family.......................... 

Weed collection of .

Common name

Scientific name.

Family. 

Weed collection of .

Common name.

Scientific name.

Family 

Weed collection of ....................

Common name.

Scientific name.

Family ........................... 

Weed collection of

Common name.....................

Scientific name.

Family. . 

Weed collection of . . . . . . . . . . . . . . . Common name.

Scientific name.

Family 

Weed collection of .....................

Common name.

Scientific name.

Family......................... 

Weed collection of ..................... Common name.

Scientific name.

Family 

Weed collection of .

Common name.

Scientific name.

Family. 



Weed-seed collection. - Take two old photographic negatives 4 by 5 or 5 by 7 size. Clean off the gelatin so that the glass is clear. Cut a piece of thick cardboard or picture mat of the same size as the glass. With a cork-cutter or auger punch out a series of five-eighth-inch holes in the card with three-eighth-inch spaces between them, leaving a half-inch between the outside holes and the edges of the card. Lay this card on the clean glass. Put the seeds you have collected in the holes, one kind in each, printing the name of the weed from which they came below the hole. Place the seeds so that those from plants in the same family may be in adjacent holes, the families arranged in order. Cover with the other clean glass and bind with passe-partout paper.

Impure seed.-Look up in any garden magazine or the spring numbers of home magazines the addresses of some seed houses. Send for small quantities of clover, grass, or some vegetable seed like cabbage or onion. Look these seeds over to see if they contain any weed seed, comparing with your weed-seed collection and with the more extensive collections in the laboratory. What sort of seeds would be most likely to contain weed seeds? What precautions could the gardener take to make sure his seed is pure?

Weed identification.-There follows a key to the common weeds of the Chicago region. Use this in finding the names of the fresh specimens of your weeds until you feel sure you can identify them with certainty.

You may work in co-operation with other members of the class, learning from them the names of weeds they have identified, but do enough of the work yourself to be ready to pass a test on the use of the Key when you are given an unknown to determine. Ada M. Georgia's Manual of the Weeds (Macmillan) gives descriptions and pictures of all the weeds. (See the library copy.) Many government and state pamphlets on weeds are to be had for the asking or at very low prices. A list of some of the best of these is given in the Source Book of Biological Nature Study.

Key to the Common Weeds of the Chicago Region: References to Gray's New Manual of Botany, 7 th Edition. Directions: Choose the first one of headings I-IX that fits the specimen you are determining. Then choose between a, aa, b, bb, etc., until you reach the name of the weed you have in hand.

\section{KEY TO THE COMMON WEEDS OF THE CHICAGO REGION}

I. Weeds with milky juice $a$-Leaves with entire or nearly entire margins

$b$-Leaves small, I inch or less in length 
c-Leaves not awl-pointed (Fig. 3a)

$d$-Low

$d d$-Tall, much branched

There are several other species, not usually occurring as weeds (see Gray, p. 545)

$c c$-Leaves awl-pointed

$d$-Leaves all with stem (petioled)

$d d$-Upper leaves at least without stem (sessile)

$b b$-Leaves large

$c$-Fields and roadsides

$c c$-Swamps

$a a$-Leaves with lobed or cut margins

$b$-Leaves in a rosette

$b b$-Leaves not rosetted, but prickly

$c$-Midrib prickly

$c c$-Midrib not prickly, but margins prickly

$d$-Stem of plant prickly

$d d$-Stem of plant not prickly

Several other species of Lettuce occur in the Chicago region, not commonly as weeds (see Gray, p. 866)

II. Weeds with compound leaf (Figs. $3 b$ and $3 c$ )

$a$-Leaves of three leaflets

$b$-A woody vine often appearing shrubby; berries white. "Leaflets three, quickly flee. Berries white, take to flight"

Poison Ivy

$b b$-Herbs of low, prostrate habit

$c$-Flowers in dense clusters (head or spike)

$d$-Blossoms white (several species) White Clover (see Gray)

$d d$-Blossoms red

$d d d$-Blossoms pink

Red Clover

$d d d d-$ Blossoms yellow

$e-$ Blossom cluster as large as thumb nail

$e e$-Blossom cluster (spike) only as large as little-finger nail

$c c$-Flowers single, leaves of acid flavor

Alsike Clover

Hop Clover

Black Medick

Wood Sorrel

$b b b$-A tall, much-branched plant; flowers in long slender clusters

$c$-Blossoms white

White Sweet Clover

$c c-$ Blossoms yellow

Yellow Sweet Clover

$a a$-Leaves of more than three leaflets

$b$-Once pinnately compound

c-Flowers purple or rose, in clusters

Vetch (several species; see Gray, p. 525)

$c c$-Flowers yellow like buttercup

Cinque foil (Gray, p. 48I) 

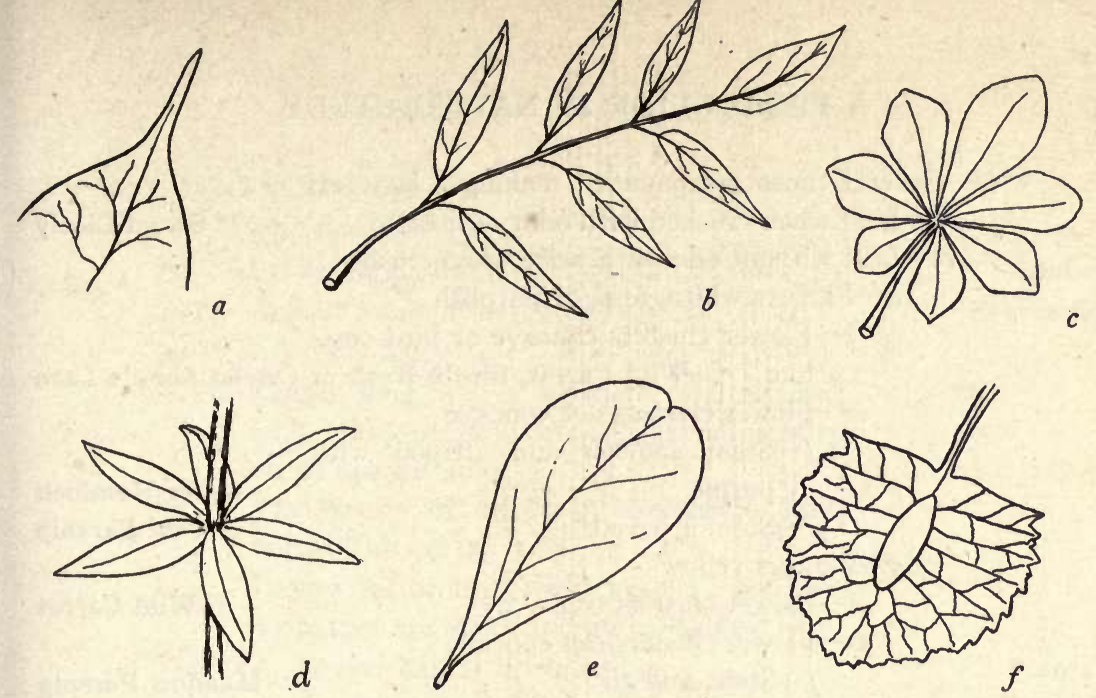

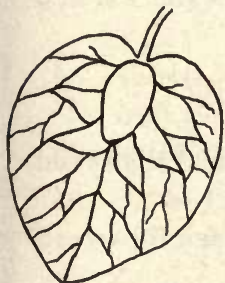

$g^{-}$
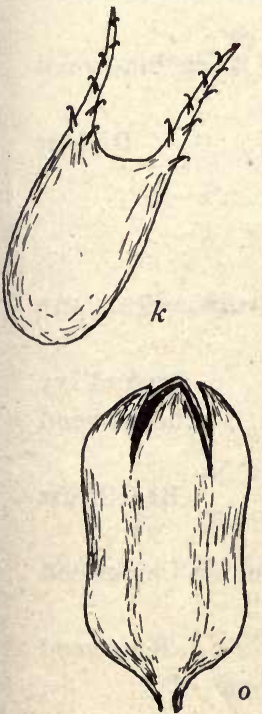
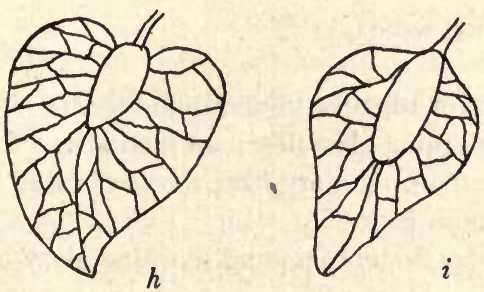

$i$
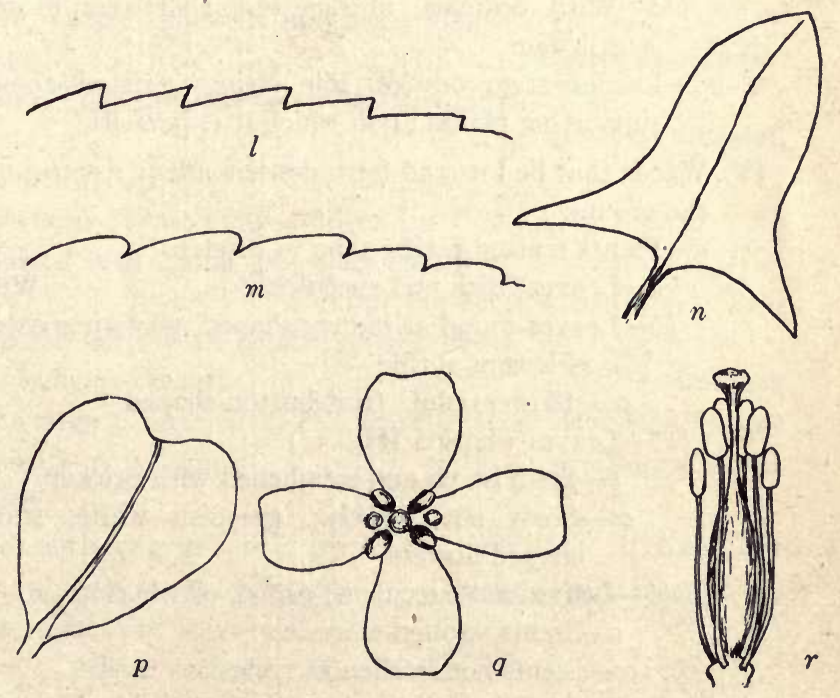

Fig. 3

$a$, an awl-pointed leaf, tip only; $b$, a pinnately compound leaf, reduced; $c$, a palmately compound leaf, reduced; $d$, leaves whorled, reduced; $e$, an obovate leaf, reduced; $f$, fruit of the great dock, $R$ umex Britannica, enlarged; $g$, fruit of the yellow dock, Rumex crispus, enlarged; $h$, fruit of the pale dock, Rumex altissimus, enlarged; $i$, fruit of the swamp dock, Rumex verticillatus, enlarged; $j$, fruit of the bitter dock, Rumex oblusifolius, enlarged; $k$, fruit of the beggartick, enlarged; $l$, saw-toothed (serrate) leaf margin; $m$, crenate leaf margin; $n$, a halbert-shaped leaf, reduced; $o$, pod of evening primrose; $p$, pod of shepherd's-purse, enlarged; $q$, a cruciform blossom from shepherd's-purse; $r$, stamens and pistil of a cruciform blossom. 
$b b$-Several times compounded making a lacy leaf $c$-Leaf when crushed with odor of licorice $c c$-Leaf without odor of licorice when crushed $d$-Flowers white, rose, or purplish

$e$-Flower clusters concave or bird-nestlike Wild Carrot, Bird's Nest, or Queen Anne's Lace ee-Flower clusters not concave

$f$-Stem smooth and striped with purple

ff-Stem grooved

$d d$-Flowers yellow

$e$-Flower clusters concave

$e e-$ Flower clusters not concave

$f$-Stem smooth

$f f$-Stem grooved

Water Hemlock

Cow Parsnip

Wild Carrot

Meadow Parsnip

Water Parsnip

III. Twining and climbing weeds

$a$-Leafy

$b$-With cordlike or ropelike underground stems

c-Flowers morning-glory-like; an inch across

$c c$-Flowers morning-glory like; considerably more than an inch

$b b$-With very large fleshy roots and morning-glorylike blossoms

Field Bindweed

Hedge Bindweed

Wild Sweet Potato

$b b b$-With ordinary fibrous roots; flowers inconspicuous

$a a$-Leafless-stem orange, like string, twisted about

Black Bindweed

supporting plants upon which it is parasitic

Dodder

IV. Weeds that lie low and form dense mats or rosettes on the ground

$a$-Plants matted rather than in rosettes

$b$-Leaves thick and succulent

Wild Portulaca Purslane

$b b$-Leaves round or kidney-shaped, wavy margins

c-Flowers purple

$c c$-Flowers pink, fruit button-shaped

Ground Ivy

Cheeseweed

$b b b$-Leaves whorled (Fig. $3 d$ )

$c$-Stem harsh and roughened with prickers

cc-Stem not prickly; greenish white, starshaped flowers

$b b b b$-Leaves not succulent, round, or whorled

$c$-Stems swollen at nodes

Bed Straw

$c c$-Stems not swollen at nodes

$d$-Spiny bracts at base of leaves, root pink

Low Amaranth

$d d$-No spiny bracts; flower greenish-white

Indian Chickweed

Knotweed 
$a a-$ Plants in rosettes

$b$-Leaves densely hairy

c-Leaves large, flowers yellow on tall stalk

Mullein

$c c$-Leaves small, flowers in pussy-foot clusters

Everlasting

$b b$-Not densely hairy

c-Leaves long, a foot or more, and narrow; fruit corky-winged, borne in great quantity on an upright stalk

Dock

The species are shown by sketches of individual fruits (Figs. $3 f-j$ )

$c c$-Leaves not so long, with conspicuous coarse fibers that are tough and pull out like string $d$-Leaves half as broad as long

Plantain

$d d$-Leaves one-fourth as broad as long or less

Ribwort or Buckthorn

V. Weeds with prickles or thorns on the stem, leaves, or fruit (for those that also have milky juice see I, p. I7)

$a$-With prickles or thorns on fruit only

$b$-Fruit a pod or capsule

c-Fruit egg-shaped, I inch or so long

$d$-Fruit green, blossom white, trumpetshaped

Jimson Weed

$d d$-Fruit purple, blossom purple, trumpetshaped

Purple Thornapple

$c c$-Fruit like a flat peapod, breaking into spiny segments

Tick Treefoil

$b b$-Fruit a "bur"

$c$ - Fruit as large as last joint of finger

$d$-Covered with strong spines, leaves threelobed

Clotbur (for species see Gray, p. 829)

$d d$-Covered with weak hooked spines, basal leaves heart-shaped

Burdock

$c c$-Fruit as large as finger nail, flat, ovoid

Hound's Tongue

$c c c-$ Fruit small, ovoid, spiny

Beggar's Lice

$b b b$-Fruit seedlike

$c$-Covered with long spines; a grass

Sand Bur

$c c$-Spines only on one end (Fig. $2 k$ )

Sticktights or Beggarticks

$a a$-With prickles on stem or leaves as well as on fruit

$b$-Fruit spiny; yellow spines at base of lanceshaped leaves

Spiny Clotbur

$b b$-Fruit (berry), leaves, and stem bear yellow spines

Buffalo Bur 
$a a a$-Fruit not spiny; only stem or stem and leaves spiny

$b$-Flowers conspicuous

$c$-Flowers clustered in heads

$d$-Heads of bloom small, $\frac{1}{2}$-inch diameter

$d d$-Heads of bloom large

$e$-Bracts on flower head spreading and prickly; leaves decurrent on stem

$e e-$ Bracts on flower head appressed, inner not prickly

$f$-Leaves whitish above, plant low

$f f$-Leaves creamy, woolly

$f f f-$ Leaves greenish above

$g$-Stem of flower head leafy, plant stem furrowed

$g g$-Stem of flower head not leafy $h$-Stem high

$h h$-Stem low

$c c$-Flowers solitary, violet, star-shaped; fruit an orange berry; stem with yellow spines

$b b$-Flowers inconspicuous

$c$-Stem grooved; spines at base of leaves

$c c$-Stem streaked with red; leaves spiny

VI. Weeds with strong odor

$a$-Odor of onion

$b$-Leaves nearly I inch or even more in width

$b b$-Leaves linear

c-Flower cluster bulbiferous; capsule not crested

$c c$-Flower cluster not bulbiferous; capsule crested

$a a$-Odor of Mint

$b$-Conspicuous whitish or purplish bracts below the flower cluster

$c$-Heads of bloom terminal

$c c$-Heads 'of bloom axillary

$b b$-No conspicuous bracts below flower cluster $c$-Flowers in terminal spikes

$d$-Leaves lance-shaped with toothed edges

(Fig. 3l)

$e$-Leaves sessile or nearly so

$e e$-Leaves petioled

$d d$-Leaves heart-shaped with serrate edges

(Fig. 3m)

Thistles

Canada Thistle

Bull Thistle

Shore Thistle

Pitcher's Thistle

Roadside Thistle

Swamp Thistle

Pasture Thistle

Horse Nettle

Spiny Amaranth

Russian Thistle

Wild Leek

Wild Garlic

Wild Onion

Wild Bergamot

Horsemint

Spearmint

Peppermint

Catmint 
$c c$-Flower clusters in axils of leaves

$d$-A tall erect plant with woolly leaves

$d d$-A low plant with small smooth leaves

Horehound

Pennyroyal

aa -With neither onion nor mint ordor; leaves much dissected, fernlike

$b$-Flowers white in flat-topped clusters

$b b$-Flowers yellow

$c$-In flat-topped clusters

$c c$-In daisy-like heads; odor disagreeable

$d$-Head $\frac{1}{2}$-inch across

$d d$-Head larger

Western Yarrow

Tansy

Dog Fennel

Stinking Willie

VII. Weeds with simple leaves that are opposite

$a$-Leaf edges entire

$b$-Fruit a berry inclosed in a balloon-like calyx

(for species see Gray, p. 7I4)

$b b$ - Fruit not a berry

c-Flowers red

$d$-Leaves heart-shaped

$d d$-Leaves lance-shaped; calyx lobes extending beyond corolla

$d d d$-Leaves linear

$c c$-Flowers orange

$c c c$-Flower̨s pink; in terminal clusters

$c c c c$-Flowers white, looking like pinks

$c c c c c$-Flowers blue, looking like pinks

$a a$-Leaf edges toothed or lobed

$b$-Stem not square

c-Leaves deeply palmately cut

$d$-Almost compound; lobes linear

$d d$-Lobes broad

$c c$-Leaves only toothed

$d$-Leaf base heart-shaped; plant provided with stinging hairs

$d d$-Leaf base not heart-shaped; no stinging hairs; small flower clusters with white ray flowers

Ground Cherry

Umbrellawort

Corn Cockle

Red Campion

Butterfly Weed

Soapwort

White Campion

Ragged Robin

Wild Hemp

Giant Ragweed

Stinging Nettle

Galinsoga

$b b$-Stem square

$c$-Blue flowers in terminal spikes

Vervain

VIII. Weeds with simple leaves; the leaves alternate

$a$-Leaves with entire edges

$b$-Leaves linear or very narrow

$c$-Plants with yellow flowers

$d$-Flowers good sized

$e$-Flowers spurred, two-lipped 
ee-Flowers with black dots along the edges of the yellow petals Common St. John's-wort $d d$-Flowers small but in good-sized clusters

$e$-Flower clusters daisy-like, with brown center

Brown-eyed Susan

$e e$-Flower heads clustered into brilliant masses of yellow

Goldenrods

eee-Flowers green, fruit a nutlet with corky wings (see "Dock" under IV, p. 20)

$c c$-Plants with white or purple flowers in daisylike heads

$b b$-Leaves lance-shaped

$c$-Leaves sessile, with sheathing stipules; one of the smartweeds with pink flowers and crescent-shaped, purple blotches on the leaves is known as lady's-thumb (see Gray. for other species)

cc-Leaves petioled; plant large, with purple berries having red juice

Asters

$c c c$-Some asters, goldenrods, and sunflowers come here (see Gray for species)

$b b b$-Leaves halbert-shaped (Fig. $3 n$ ), of acid flavor, ovoid

$b b b b$-Leaves large; root large and pink

Smartweed

Pokeweed

$a a$-Leaves with toothed or wavy edges

$b$-Leaves broad, oval or halbert-shaped

$c$-Leaves, at least the basal ones, ovate; sometimes three-pointed, like a goose's foot $d$-Blossoms green, inconspicuous; seeds black

$d d$-Blossoms white, like potato plant; fruit a purple berry

$c c$-Leaves halbert-shaped (Fig. $3 n$ )

Lamb's-Quarters

Sheep Sorrel Rough Amaranth

$b b$-Leaves narrow, at least the lower ones lanceshaped

$c$-Individual flowers large

$d$-Flowers yellow; seed pods four-angled (Fig. 30)

Evening Primrose

$d d$-Flowers purplish, pink, or whitish

$e$-Flowers clustered in terminal racemes

$e e$-Flowers solitary at ends of upper branches

Willow Herb

Nightshade Halbert-leaved Orach 


$a a a$-Leaves, at least basal ones, deeply cut

$b$-Seed pods numerous, small, lozenge-shaped, and peppery to taste

Pepper Grass

$b b$-Seed pods numerous, heart-shaped, flaıened (Fig. $3 p$ )

Shepherd's-Purse

$b b b$-Seed pods not as above

$c$-Leaves cut into linear lobes

$d$-Flowers yellow, cruciform (see Fig. 3q)

$e$-Leaves sweet-scented but with very bitter taste; flower clusters in leaf axils

Wormwood

$e e$-Leaves with strong, unpleasant odor; flower clusters at end of branches

Ragweed

$c c$-Leaves merely irregularly cut, not in linear lobes

$d$-Flowers in heads

$d d$-Flowers not in heads, yellow, cruciform

$e$-Flowers $\frac{1}{2}$ inch across; seed pods with long beak

$f$-Basal leaves lance-shaped

$f f$-Basal leaves reverse lance-shaped

$e e-$ Flowers $\frac{1}{4}$ inch across; pod four-angled

eee-Flowers $\frac{1}{8}$ inch across; pod round and hairy

Other species occur, but usually not as weeds (see Gray, p. 426)

Oxeye Daisy

The Mustards

Charlock

White Mustard

Black Mustard

Hedge Mustard

A study of a single weed.-Select some weed with good-sized flowers, like bouncing Bet, Jimson weed, evening primrose, or wild mustard. First, examine the whole plant out of doors and notice the parts-root, stem, leaf, blossom, and fruit. Dig out the plant to see the extent of the root system. Sweet clover is a good weed to try this on for comparison, for the roots are tough and may be readily traced. Moreover, on its roots are often found those nodules of nitrifying bacteria so characteristic of the legumes. Some member of the class should look up and report on such plants and their use. Write out an abstract of this report.

Cut a cross-section of the stem and see the ring of fibrovascular bundles. These are particularly well shown in the leaf stem of another weed, plantain. Let each pupil break this stem and see how tough the stringy, fibrovascular bundles are. Take hold of one and pull it out; note how it runs up into the leaf, branching and forming a conspicuous part of the leaf vein. Draw the leaf stem to show the fibrovascular bundles.

Flower. - In the wild mustard note the four sepals on the outside of the flower at its base. Altogether they constitute the calyx. Within these 
are the four yellow petals making up the corolla. These inclose and protect the essential parts of the blossom, stamens, and pistil. Four of the stamens are of equal length, two others longer. Note that each stamen consists of (I) a basal stalk, the filament, which bears (2) an elongated case, the anther, in which the pollen is held. You have probably noticed this yellow dusty pollen in the Easter lily or possibly in the buttercup and as a child have put your nose into some flower for the purpose of getting it colored with the yellow pollen. At the center of the flower is the pistil, made up of (I) a swollen base, the ovary, (2) a stalk-like style, with (3) a sticky knob at its end, the stigma. Parts similar to these will be found in any of the other flowers.

Origin of fruit.-Examine a mustard plant old enough to show the seed pods. Where are the largest seed pods? Following up the younger and younger ones you see that the seed pod arises from what? With a sharp knife make a section of such a large ovary as is to be found in the nasturtium blossom or mandrake. There will be seen a number of tiny objects looking like diminutive seeds. These are really the ovules. In them are the eggs, tiny things that can be seen only under the microscope. Read up the process by which the egg is fertilized by means of the pollen and what happens in consequence and write a statement of it that would be intelligible to a sixth-grade child.

All living things from eggs.- Open mature pea pods. Do you find, in some of them, in addition to the well-formed peas, some tiny objects growing where you would expect a pea to be? These are the ovules whose eggs were inadequately fertilized. Unless the egg in the ovule is fertilized it does not grow into the new little plant. It is well-nigh universally true that except among the very simplest animals and plants every living thing comes from an egg and that this must be fertilized before the developmental process will begin.

Anemophilous and entomophilous flowers.-Fertilization is so important that plants have many devices to make it certain. Some flowers are selfpollinated; that is, the pollen of the stamens is dusted onto the stigma of the same flower. Such flowers do not need to open at all. But as a rule the pollen is carried to another flower, for it has been proven that more seeds and seeds with greater vitality are produced by cross-pollination than by self-pollination. In general the plant either depends for crosspollination ( $\mathrm{I}$ ) on an abundance of pollen so that the wind will carry it from flower to flower or (2) on insect visitors. The ragweed is an example of a wind-pollinated plant. Shake a large plant of this kind growing in the field and see it "smoke" as the pollen falls in clouds. Such windfertilized plants usually have inconspicuous blossoms. 


Color, perfume, nectar.- The showy flower is an advertisement to the insects that their presence is desired. The attractive color is often supplemented by pleasing odors. The visiting insect is also enticed by nectar. You have probably bitten off the spur of a violet or a columbine blossom to taste this. Color lines and blotches on the blossom sometimes point the way to the desirable nectar. As in the ancient world all roads led to Rome, so in the flower world all lines lead to the nectar. (Read W. Hamilton Gibson's "Welcome of the Flowers" in Harper's Magazine, LXXXVIII, $55^{\mathrm{I}-56}$. This will give an idea of the devices found in blossoms to insure their cross-pollination by insects.)

Personal observations.-Study some particular plant to see: (I) how many insects come to a blossom like milkweed, horsemint, fireweed, or red clover in an hour; (2) whether one sort of insect, like the bumblebee, fly, butterfly, or honeybee, confines its attention to a particular flower or whether the flower in question welcomes all sorts of insects; (3) in what ways a particular flower is adapted to a particular insect. The following are some good plants to watch: butter and eggs, spotted balsam, evening primrose (why "evening"?), beardtongue, horsemint, nightshade, Jimson weed, and rose mallow. Record your observations on the opposite page.

The study of a familiar weed, a dandelion.-Dig up a dandelion. What sort of a root has it?. Is this an advantage or disadvantage to the plant? Do dandelion roots have a commercial value? How are the leaves of the dandelion arranged? Name some other plants that have the rosette habit. In what way is this profitable to the plant? Do dandelions blossom early in the spring? Can you see what makes this possible? Draw an outline of a dandelion leaf. Is the shape of the leaf in any way dependent upon arrangement of leaves on the plant? What is the taste of a dandelion leaf? Would this be of any service to the plant? What is commonly called the dandelion blossom is really a cluster of blossoms; each one very small. Compare a single blossom with this sketch, and record the parts as we have seen them in our study of the mustard flower. What benefit would the plant derive from having the tiny blossoms bunched as they are here or in a clover bloom? Observe a dandelion plant in blossom. Are the stalks on which the blossom clusters are held standing up straight or lying down? Do the stalks bearing the seed cluster or "blow balls" stand up or lie down? What is their position in wet weather? 
What is the position of the cluster in which the fruits are yet unripe? Examine one of the fruits with its silky parachute. What position does it take when sailing in the air? Take hold of the parachute and gently pull what appears as the seed between thumb and finger. Do you feel the tiny points on it? Move it in the opposite direction. Do the projections have their points turned up or down? Of what use are these hooks to a ballooning seed?

Weed travelers. - List on the opposite page fifty of the weeds you know and indicate in each case of what part of the world the weed is a native. The information can be found in Gray's Manual or similar botanical texts. Unless it is stated that the plant was introduced from some foreign locality the presumption is that it is native to North America. Would you call weeds good travelers? Find the facts regarding the date of introduction of the Russian thistle to this country and the rate of its spread; of Jimson weed; of deadly nightshade.

Definition.-A weed might be defined as an eminently successful plant growing where man does not want it. It is because they are such bold, adventurous, capable organisms that they are interesting. Let us inquire why weeds are so successful that they perpetually threaten man's attempt to cultivate his corps.

Rate of seed production.-Most of them produce enormous quantities of seeds. Count the number of seeds in a pod of the wild mustard, bouncing Bet, or any other annual. Count also the number of pods on one goodsized plant. How many seeds does this plant bear? On the basis of this average calculate how many years it would take to cover the land's surface, starting this year with a single plant and supposing that all seeds find a place to grow and none die. Can you find out from any source how many seeds single plants of the following weeds produce: white mustard, tall pink root, lamb's-quarters, purslane? Lift out a square foot of soil two inches deep from some spot in a vacant lot and put it in a shallow box. Keep it moist, in the schoolroom, and count the number of weeds that appear. In the same way take up the next four inches of soil and record the number of weeds that grow from it. It will be interesting to find out to what depth there are weed seeds that will germinate. There are stories printed occasionally in the newspapers that seeds buried along with mummies in the old Egyptian days have germinated when planted. Find out what experiments have shown to be the maximum length of life of seeds and record the result here.

Methods of dispersal.- Seeds have facilities for wide dispersal. Why is it essential that seeds should be carried away from the parent plant? List here some of those that are carried by wind and draw three such, 


enlarged, to show different devices for wind carriage. Examine the fruits of the sour or curly dock and draw one enlarged. Can you think how the corky rim of this seed would serve in carrying it to new locations? Draw a bur of the cocklebur. How are such seeds carried? List some other weeds whose fruits are carried in a similar way. Of the two seeds in a bur of the cocklebur, one germinates the first spring after production, the other not until the second spring. How would this be advantageous? Touch the ripe pods of the wild balsam. What happens? Find out how the wild cucumber spreads its seeds. (Read Lubbock's Flowers, Fruits and Seeds, pp. 52-66.) Many weed seeds are eaten by birds, and some of them are so hard-shelled that they pass through the digestive tract unharmed. Most of them are digested, however. If the seeds or fruits are poisonous, would it be advantageous to the plant? Find some figures to show how many weed seeds are eaten by birds. See report from Yearbook, Department of Agriculture, S. H. Judd, "Birds as Weed Destroyers." Enter on the opposite page some of the facts given in this report.

Other methods of propagation.- Weeds reproduce also by other means than seeds. Many have underground stems that run along under the surface and send up new shoots at intervals. When these underground stems are cut in pieces by plowing or spading, each piece may produce a new plant. List some that have this habit. Many weeds send out runners that strike root at their tip; name some. Some have prostrate or decumbent stems that strike root at each node; name some of these. Suppose such weeds were tramped upon by cattle, broken into pieces by their sharp hoofs, and at the same time pressed into the ground, how would it profit the plant? Name some pasture plants that behave so.

Protection.-What weeds have some very adequate means of protection? Name some that have specific devices for keeping warm.

The following weeds are protected from browsing animals as indicated:

is protected by stiff hair. is protected by disagreeable taste. is protected by irritating juices. is protected by thorns on its stems. is protected by prickers on its leaves. has fruit covered by prickers. 


\section{ANIMALS OF POND AND STREAM}

Field trip.-On this trip the student should be provided with a net similar to the one used for insects. The wire frame must be very strong and the net need only be twelve or fifteen inches deep. Several pint jars or wide-mouthed bottles should be taken. Go to pond or stream margin and dredge for animals. Look under stones for crayfish and capture some. Dredge along the weedy bottom, dumping the contents of the net into a pint jar. Take this back to the schoolroom for later examination. Dredge out material from several spots along the shore and dump the material obtained on a bare spot on the ground. Pick out the animals as they wriggle out of the material and put them in the pint jars partly filled with water. You will probably have little difficulty in collecting the water sow bug and the bender, both fair-sized relatives of the crayfish. Try to obtain, also, dragon-fly and damsel-fly nymphs, mosquito larvae, larvae of the water beetle, the May fly, and the stone fly. Take these back to the schoolroom in the pint jars. If possible secure specimens of diving beetles, water boatmen, back swimmers, and water scorpions, and learn to know the whirligig beetle, water strider, caddis-fly larva, and the common water spider. Quite likely several trips may be necessary to secure this material. Take back in the jars some of the plants found growing in the water. On the return to the schoolroom put several sprays of plants in the aquarium jar on your desk and then dump in the animals brought back from the trip that you especially wish to save. Fresh water may be added from the tap.

Study of crayfish and its relations. - Put the crayfish in a small glass dish or shallow pan that is partly filled with water. Notice the parts of the animal. In what ways is it like an insect? in what ways different? How does it compare with the land sow bug? How many feet has it? Does it use them all in walking? Does it have any other means of locomotion? Stick your pencil point down near it. How does it behave? How many of the feet are provided with pinchers? Are the great pinchers on the forelegs of equal size in all specimens? Can you account for this? What sense organs can you see that the animal possesses? How are the feelers used? Darken half of the dish: does the crayfish distinguish between light and dark? As the animal stands quietly in the dish look squarely at him from in front. What do you see moving? Drop a little powdered chalk into the water just in front of him. How does this move as it sinks near him? 


Can you detect his method of breathing? Look at the prepared museum specimens showing the gills. Probably some of the specimens collected will bear eggs. Where are these attached? Look up the life-history and see if the eggs develop into nymphs or larvae.

Plankton.- Compare the water sow bug and the bender with the crayfish. In some of the material that has been brought back from the pond and allowed to stand in the jars you will probably see some very much smaller relatives of the crayfish. Learn to recognize the Daphnia, Cyclops, and Cypris. These crustaceans, while apparently insignificant, are of large economic importance. Find out their use. Find out how abundant they are in lake or river water, and also how rapidly they reproduce. The sum total of small plants and animals floating or swimming in the water is known as the plankton. Find out from books how much there is of it in ordinary lake or river water.

Study of the dragon-fly nymph.-In the material dredged up from the pond the nymphs of the dragon fly and the damsel fly will undoubtedly be found. These as well as other insect larvae may be determined by the accompanying key. In our insect study we have observed dragon flies laying their eggs. The eggs hatch into the tiny nymphs. Have you the nymphs of more than one kind of dragon fly? Lift one of the good-sized nymphs from the water and observe the construction of the accessory jaws borne on the arm that hinges below the mouth. You can gently take hold of this pair of accessory jaws and extend the arm. How would they serve in capturing prey? Keep some of the largest of the dragon-fly nymphs in a jar by themselves, supplying them freely with smaller insect larvae for food. Put a stick in the jar so that it will project above the water and cover the jar with a piece of cloth. Probably some of the nymphs will mount the stick and transform into the adult dragon fly. The process is well worth watching. Look on the grasses and rushes along the margin of the pond for such cast-off skins.

The mosquito's life-history.-You will probably find mosquito larvae or pupae in the water brought back from the pond. If not, make a special trip for them. The larvae are the wrigglers often found in a rain barrel or other stagnant water. Put several of them into a tumbler of water and watch their movements. When undisturbed where do they rest? Are they lighter or heavier than water? Is it an effort for them to go down under the water? How do they accomplish this? Do they have jaws? Learn to recognize the pupa. What is its position at rest? Make a sketch of the larva and of the pupa. Cover the tumbler in which there are a number of pupae and watch for the transformation of the pupa into the adult mosquito. Where does the adult stand while it is drying its wings? 
Put a couple of minnows or other small fish into the aquarium where there are mosquito larvae and pupae. What happens? Put a number of larvae into each of two tumblers two-thirds full of water. Drop a drop of kerosene oil on the surface of the water of one of these tumblers. What happens? What practical application is made of this?

Movements of animals of pond and stream.-How does the dragon-fly nymph usually move? Poke at it with your pencil and see in what other way it moves. You may have to read to some extent to understand how it accomplishes this. Is the diving beetle, Dytiscus, heavier than water or lighter? How does it swim? Is its shape one that would fit it for movement through water? How are the legs adapted to swimming? Watch the swimming of the giant water bug, the back swimmer, the water boatman. How do they swim and how are they structurally adapted to so moving? Draw some one of them and make an enlarged sketch of the leg to show the adaptations. Watch the water spider or the water strider as it runs on the water. Sketch the shadow of the water strider seen on the bottom of pond or aquarium. How does the strider accomplish the miracle of walking on the water? Blow a soap bubble with a pipe and let the bottom of it rest on the surface of the soapy water, then lift the pipe. Is the bubble drawn out of shape? This shows what? Hold a fine needle between thumb and finger a very short distance above the water in a full tumbler, the needle parallel to the surface of the water. Let it drop to the surface. If the experiment is done carefully the needle will remain on the surface. Look up the experiment with the Mensbrugge float and try it.

Is the goldfish heavier than water, lighter, or of the same specific gravity? Are you heavier than water or lighter than water? Why then does one drown? Does a fish have anything in its body that helps to keep it afloat?

If you were to cut through the fish's body from snout to tail what would be the outline of the surface exposed? Draw it. Draw the outline to represent the line on which the hull of a boat cuts the surface of the water. What is the shape of a submarine? How many fins has the goldfish (or the chub)? Where are they located? How are they used? What fins does the fish use chiefly in swimming? How does it turn around? How does it turn toward the surface? Watch the turtle in the water. What methods of locomotion has it? How does it swim? Watch a snail "crawl." How does it do it? Can it crawl on the surface of the water? Can it swim?

Breathing.-What is the position of the diving beetle when at rest? of the back swimmer? Take Dytiscus out of the water; lift up the elytra or horny wing covers. Note the membranous underwings, the ones he really uses in flight. What else is between the elytra and the abdomen? 

What do you find on the segments of the abdomen? Examine one with the hand lens and draw what you see. Can you now tell why he assumes his resting position? Probably some of the other water beetles in the aquarium will show a silvery mass on the abdomen. Examine the abdomen of such an animal when taken from the water. Is it still silvery? With what is it covered? Dip a mullein leaf in water and note its appearance. What is your conclusion? What device has the mosquito larva to facilitate breathing? How does the pupa breathe? Observe the rat-tailed maggot and the water scorpion to see how they have solved the problem of respiration under water. (Find out from books if specimens are not to be had.) How has man solved the same problem? Read up on the life-habits of the diving spider and find out where her eggs are laid and how she supplies her young with air. Did insects probably originate in the water and later come to live on land, or are they essentially land animals, some of which have taken to water?

How does the fish breathe? Fill a small wide-mouthed bottle with carbonic-acid gas from a generator and tie a piece of Bologna sausage skin over the mouth. Drop it into a pint fruit jar one-third full of water. Test the water at once with litmus paper to see if it is acid. Cover the jar. Test the water again after it has stood for a few hours. What is the application of this experiment to the breathing of a fish or of yourself? Examine larvae of the following insects and see if you find gills: damsel fly, May fly, and stone fly.

How does the turtle breathe? the frog? Many of the water snails have a lung cavity, the opening into which may be seen beside the shell.

Capture of prey and feeding. - Watch the dragon-fly larvae in the aquaria. Are they active or sluggish? Are they easily seen? How do they secure their food? Watch the larva of the diving beetle, known as "the water tiger," in an aquarium where there are water sow bugs, benders, or insect larvae. How does it secure its food? Put an "electric light bug" or giant water bug into the aquarium with a couple of small fish or a small frog. Watch to see how he captures the animals. Notice the position in which the front legs are carried. Observe their structure to see how they are particularly adapted to the capture of the prey. Notice the front legs of the water boatman, the back swimmer, and the water strider. Pick up the "electric light bug," holding it between the thumb and finger by the edges of the body. Notice the mouth parts are arranged to form a suckingtube. This is one of the structural peculiarities of the bugs. This type can inflict a painful wound, so be careful in handling the insect. Knowing the structure of the mouth parts it will now be easier to understand how the animal makes way with its victim. 
Put the crayfish in a small glass dish and offer it some scraps of raw meat. Observe how these are handled. Notice how the jaws move. There are accessory jaws in the crayfish as there are in the cricket. Feed the turtle with some scraps of raw meat. How does he secure it? He probably will help himself to fish, frogs, or other similar animals that are left in the aquarium with him unless he is well fed. Confine a toad in a jar with some earth at the bottom. Then put in some house flies, crickets, or other insects. Can you observe how he captures them?. Look up in some book the method of attachment of the toad's tongue in its mouth and draw a diagram to show this.

Snails.-See specimens of the following different sorts of water snails: Campeloma (or Vivipara), Limnaea, Pleurocera, Goniobasis, Physa, Planorbis, and sketch the shells of those written in italics so as to bring out the distinguishing features.

Many of the snails live on the land seeking, however, very moist situations. The commonest large sorts in our region belong to the genus Polygyra. Specimens of this or of the edible snail to be had at the fish market may be kept in a moist glass jar and fed lettuce or cabbage leaves. Note the sense organs, the antennae, and the eyes of the snails. The eyes are carried on stalks that can be withdrawn. How does the snail shell serve the animal? Note how the opening of the shell is closed in the living animal by the horny operculum in such a snail as Vivipara. Note the lines of growth on the shell. Where is the new material deposited as the shell grows? Can you see the original shell?

Snail eggs will often be found as translucent spheres imbedded in jellylike material that forms masses as large as beans on the sides of the aquaria or on the water plants.

Clams.-Put a live clam in the aquarium with sand on the bottom. Note the white fleshy foot at the front end by means of which it crawls. When the animal is at rest the breathing- and feeding-tubes or siphons are seen at the hind end. Dust a little finely powdered chalk into the water so it will sink near the siphons. Can you tell which one takes the water in and which serves as an outlet? See the museum specimens of dissected clams to see the gill chamber into which the siphons lead. Take the clam from the water. How tightly does he close his shell? Can you pull it open? Examine a clam shell to see the lines of growth on the outside. How are they arranged? Can you see the original tiny shell? The two halves are fastened together along a hinge line. Note the furrows and ridges on the inside of the shell that interlock so the valves or halves of the shell will come together accurately. Note the impression made on the inside of the shell by the attachment of the strong muscles that hold the valves together. 


The smooth pearl lining to the shell is what gives it value for "pearl buttons." What service does the pearl lining render to the animal? Do you find little rounded knobs on this pearly lining in some shells? Can you explain them? What are baroque pearls? What is the value of the pearls obtained in the United States from fresh-water clams? of the buttons made from their shells? Where is the chief center of this button industry?

Frogs.-The commonest frogs in our region are the bullfrog, green frog, leopard frog, pickerel frog, cricket frog, and tree frog. Learn to recognize these and also the common garden toad. When is the latter an animal of the ponds and streams? What advantage would it be to have toads in the garden? How may you provide inducements for them there? On what does the bullfrog feed? How does the frog or toad breathe? Watch the frog swim in the pond or aquarium. What is the advantage of the webbed foot? The tree frogs climb on plants to secure insects as food. Keep one in a jar with a spray of plant and watch to see it climb the sides of the jar or on the plant. Draw a foot to show the climbing device. Cut a circular piece of leather two inches in diameter from an old shoe top and with a needle run a string through its center. Tie a knot in the end of the string so it cannot pull out. Soak the leather a while in water. Apply it to a piece of glass, knot side down. Press the edges against the glass. Pull on the string, trying to lift the leather from the glass. What does the experiment show and what is its significance at this point?

The common tree frog (Hyla versicolor) is said to change its color readily when on varicolored backgrounds. Put one in a glass-topped box lined with green paper. Does it become green? Reline the box with brown and put the frog in it; does it change its color? How long does it take to change? Try orange, red, and black.

Frogs' eggs.-About the middle of April obtain some frogs' eggs from the pond early in the morning. Toads' eggs may be secured three or four weeks later. Some of the eggs will be found in early stages with about half the surface white, half black, and a single faint line crossing the black portion. When the eggs are laid by the female, each is a single large cell, a spherical mass of living protoplasm more or less filled with yolk granules. At the same time the males discharge the sperm into the water and one of them unites with an egg, so fertilizing it. (Recall fertilization of the flower.) The egg now proceeds to divide and subdivide; watch this process in the schoolroom, taking a few eggs for the purpose in a shallow glass dish with a little water and placing them under the simple magnifying glass. Later the spherical mass of small cells formed by the continued subdivisions changes its shape to become the tadpole. Supplement your own observations by those of other members of the class if you cannot stay by the 
magnifier to watch all the changes. Record the observations somewhat as follows:

April I6

7:10 A.M. Eggs are divided into two parts and the line begins to show dividing each of these parts again.

7:45 A.M. Eggs are now four-celled (drawing).

8: IO A.M. I can see a new line of division coming in nearly around the middle (drawing), etc.

Keep the record as complete as you can, recording the important events in the whole life-history of the frog or toad.

When you find the eggs in the pond they are imbedded in a mass of jelly. Of what use is this? Which side of the egg is uppermost, the black or the white? Can you see that this is any advantage? It may help you to think this out if you recall the color of the pond bottom. Recall also the color of the clothing you prefer to wear in summer. By what means do we usually hatch eggs?

Tadpoles. - When the tadpoles hatch out, where do they go and what do they do? When they begin to feed, what do they eat? How do they eat? How do they breathe? Are they "fish" or frogs now? Keep a few of them and try to rear them. Secure also some large tadpoles from the ponds and put them in an aquarium at one end of which is a bank of sand above the surface of the water, so the young frogs may crawl out on the land. Watch to see the legs develop and the tail disappear. They must now be fed on insects. By what means are they now breathing?

Turtles.-Among the commonest turtles are the following (learn to know these at least): the western painted pond, the snapper, the geographic, the spotted, the soft-shell, the box. See the museum specimen of the turtle's skeleton. What really is its shell?

Fish.-There are a number of wonderfully brilliant and interesting small fish in our streams. These may be kept in schoolroom aquaria and are very attractive. Learn to know the pumpkin seed, blue gill, redbellied dace, common shiner, brook silversides, chub, mud minnow, and rainbow darter.

Aquarium.-A school aquarium is easily made as follows: Obtain nine lineal feet of half-inch angle tin from a tinsmith. Cut this and solder together so as to make a frame $6 \frac{1}{2}$ by $8 \frac{1}{2}$ by ro inches with the open side of the angles of the tin turned in. Obtain one piece of 8 by ro window glass, 2 pieces 6 by ro and two pieces 6 by 8 . These may be cut of old window glass with a wheel glass-cutter. Make a cupful of cement with $8 \mathrm{oz}$. of whiting, $x$ of litharge, and $x$ of red lead. Mix these dry, then add some raw linseed oil, stirring it in with a putty-knife. When, very stiff take it 


in hand and squeeze it to get in more of the dry cement. Keep the hands powdered with the latter. Work it to the consistency of putty.

With the putty-knife lay a rim of this cement around the edge of the 8 by ro glass. Press this, cement rim down, into the frame for the bottom of the aquarium. Trim off the excess of cement. Similarly set the 6 by ro pieces for the sides and then the 6 by 8 pieces for the ends. Roll out ropes of the cement and press these into all the angles where glasses meet. Let stand for twenty-four hours; it may then be used, even though the cement is not hard.

The balanced aquarium.-The aquarium is to be stocked with plenty of water plants and a few animals. A couple of minnows, two or three dragon-fly nymphs, and a couple of snails are enough animal life for one aquarium. Keep the top covered with a piece of glass to prevent evaporation. The water does not need to be changed except as it becomes very dirty. When plenty of plants are present they will give off an abundance of what the animals need. What is this? The animals will supply what the plants need. What? Under such conditions the aquarium is balanced. The following are some of the best of the plants to use in the aquarium. Make a sketch of enough of each so you can recognize it and remember it. Cabomba, water milfoil (Myriophyllum), hornwort (Ceratophyllum), bladderwort (Utricularia), water buttercup (Ranunculus aquatilis), ditch moss (Elodea), eelgrass (Vallisneria), pondweed (Potamogeton). These water weeds, all flowering plants, are themselves very interesting. Note that the leaves are long, slender, and thin or else very much cut up so their parts are threadlike. Can you tell why? The water buttercup often grows partly in the water and partly out, when the leaves are of two sorts. What are they and what is the significance of their varied form? 


\section{TREES}

Provide yourself with a medium pencil and a pan of water colors. Select some typical tree for study and be seated one hundred feet or more distant from it, so you will not be confused by too-great detail. On the page opposite attempt a pencil sketch of the tree, making the sketch, say, six inches high. This may be done without previous training in drawing, for the purpose of the sketch is to make you observe the tree carefully, noting its proportion, general shape, method of branching, massing of foliage, light, and shade. The resulting sketch may be very crude, but if it is a faithful attempt to record what is actually seen it will accomplish the purpose. Try a second sketch if the first does not satisfy you. Attempt a water-color sketch of the tree. Use a fairly large brush, mix up plenty of color, and apply it quickly in an attempt to show the same things portrayed in the pencil sketch and also the color effects.

Twigs. - Obtain a twig of horse chestnut or of lilac. Draw a sketch of the twig to show the position of the buds, the leaf scars, and the lenticels of the bark. Draw carefully the leaf scar of the horse chestnut, the ailanthus, and the catalpa. You will see in each leaf scar a number of conspicuous dots. What are these? Is the arrangement of them typical for each sort of tree.

Leaves.-Secure leaves of the elm or basswood, of the horse chestnut, and of the ailanthus or ash. Make a sketch of these leaves and label the first a simple leaf. The horse chestnut and the ailanthus or ash are samples of compound leaves, the former palmately compound, the latter pinnately compound. What other trees in your neighborhood have simple leaves and what ones have compound? Do you find any other palmately compound leaves?

Bud arrangement.--Secure twigs of maple, elm, poplar, sumac, ash, basswood, and willow, selecting in each case a good, straight twig. Which of these have opposite buds and which have alternate? Do the twigs have the same arrangement as the buds? Why? Where are the buds with reference to the leaf scars? Do the buds come out at any spot on the twig or are they confined to certain points? Select a straight twig of basswood. Notice that you can readily find a bud that is immediately over another one farther down the stem and that between these two there is another bud on the opposite side of the stem. If you were to hold a string on the 





first bud, pass it on to the second bud, twisting it around the stem as needed, and then on up to the third bud, the string would make one spiral turn around the stem and touch two buds to get from the one with which you started to the one just above it. The bud arrangement on such a twig might be represented by the mathematical arrangement $\mathrm{I}$ over 2 , in which the 2 indicates the number of buds in the cycle and the $I$ the number of turns taken around the stem. In the same way find the "fraction" that indicates the bud arrangement on other twigs with alternate buds. You will find that the fraction series runs: $\frac{1}{2}, \frac{1}{3}, \frac{2}{5}$, etc. What do you find is the next fraction in the series? Study the series to discover the relation between the fractions so that you can tell without actually finding the twig what the fifth fraction in the series is.

Parts of bud.-Secure twigs of horse chestnut, lilac, white poplar, or any others that have good-sized buds. Pick a bud to pieces and arrange the parts as they occur in the series. What do you find on the outside of the bud? what on the inside? What, then, is a bud? What really are these protective covers? Cut a bud open lengthwise and draw a diagram representing the section. Do the same with an onion. Comparing the two, what would you say is the real nature of an onion? How does it differ from a bud?

Common trees.-Learn to know the following trees both in their summer and in their winter condition. Refer to such books as Blakesley and Jarvis' Trees in Their Winter Condition, Apgar's Trees of North America, Hough's Trees of the United States, Lounsberry's How to Know the Trees. There follows (p. 42) a key that will serve to identify the common trees of this region.

Acer negundo: box elder

Acer rubrum: red maple

Acer platanoides: Norway maple (introduced)

Acer saccharinum: soft maple

Acer saccharum: sugar maple

Aesculus hippocostanum: horse chestnut

Ailanthus glandulosa: ailanthus

Alnus vulgaris: European alder

Betula alba papyrifera: white birch

Catalpa speciosa: catalpa

Celtis occidentalis: hackberry

Cercis canadensis: redbud

Crataegus Crus-galli: hawthorn

Fraxinus americana: white ash

Fraxinus nigra: black ash

Fraxinus pennsylvanica: red ash 
Fraximus quadrangulata: blue ash

Ginkgo triloba: maidenhair

Gleditsia triacanthos: honey locust

Gymnocladus dioecia: Kentucky coffee

Juglans cinerea: butternut

Juglans nigra: black walnut

Juniperus communis: juniper

Juniperus virginiana: red cedar

Larix laricinia: larch or tamarack

Morus alba: white mulberry

Morus rubra: red mulberry

Nyssa aquatica: tupelo

Nyssa sylvatica: sour gum, pepperidge

Platanus occidentalis: sycamore

Picea excelsa: Norway spruce

Pinus banksiana: scrub pine

Pinus strobus: white pine

Pinus sylvestris: Scotch pine

Populus alba: white poplar

Populus balsamifera: balsam poplar

Populus deltoides: cottonwood

Populus grandidentata: large-toothed aspen

Populus heterophylla: downy poplar

Populus nigra italica: Lombardy poplar

Populus tremuloides: aspen

Prunus serotina: black cherry

Ptelea trifoliata: hop

Pyrus americana: mountain ash

Pyrus ioensis: prairie crab

Quercus alba: white oak

Quercus macrocarpa: bur oak

Quercus rubra: red oak

Quercus velutina: black oak

Rhus glabra: common sumac

Rhus typhina: staghorn sumac

Robinia pseudacacia: black locust

Salix nigra: black willow

Thuya occidentalis: arbor vitae

Tilia americana: basswood

Toxylon pomiferum: osage orange

Ulmus americana: white elm

Ulmus fulva: red elm, slippery elm 


Tree map.- On the blank page opposite make a tree map of the block bounded by the following streets:

Put a dot on it for location of each tree, numbering the same sort of tree with the same number. Make a list of the numbers below the map indicating the tree to which each refers.

Growth.-Examine the twigs from the horse chestnut or the maple or ash and see if you can determine the length of twig that was added last year; the year before last. Draw a twig to show the marks that indicate the limits of each season's growth. Make a cross-section of the terminal twig and examine the end. Notice at the center the pith, around this the wood cylinder, then a layer of soft tissue, just outside of which is the bark. Cut a two-year-old twig. How many wood rings are there in it? Examine a cross-section of a tree trunk. Count the rings of growth. Find out from your reading how nearly the number of annual rings coincides in temperate regions with the age of the tree. Examine the stump of some large tree to determine its approximate age. What was happening in this neighborhood when it was a seedling?

The ring of soft tissue between the bark and the wood is the area where the new wood and bark form. We have seen in such annuals as the weeds that fibrovascular bundles are arranged in a ring. These crowd together and form a new wood layer next to the old wood and a new bark layer next to the bark. Between these the soft tissue known as the cambium layer grows rapidly in thickness in the spring and in it the new fibrovascular bundles are formed. This cambium layer is easily broken down, and it is this fact that renders it possible to make the willow whistle. Find out how to make the whistle and try it. In the cross-section of the tree trunk notice the thin lines that run from the center toward the margin; the medullary rays. What makes these?

Shade trees.-What trees of our region are most commonly used for shade trees? Which of the shade trees is the most ornamental? What trees will grow best in sandy soil? What sort of soil does the elm require? Is there any objection to the sycamore as a shade tree? How extensive is the root system of a tree? What is the best time for transplanting trees? Why? How much soil needs to be taken up with the tree? Why are the branches trimmed off pretty severely when a tree is transplanted? 


\section{KEY TO TREES OF THE CHICAGO REGION BASED ON EASILY RECOGNIZED DISTINGUISHING FEATURES}

A. Trees bearing cones and needle-like or scalelike leaves that (except the larch) remain on the year round, i.e., are evergreens

$a$-Leaves scalelike, overlapping

$a a$-Leaves needle-like

$b$-Needles $2-5$ in clusters

$c$-Needles 5 in cluster

$c c$-Needles 2 in cluster, $\mathrm{I}-\mathrm{I} \frac{1}{2}$ in. long

Arbor Vitae or White Cedar

(other pines occur in the parks)

$b b$-Needles single

c-Needles spreading on opposite sides of twig

like barbs of a feather

$d$-Needles $\frac{1}{2}$ in. or more long; bark blistery

$d d$-Needles less than $\frac{1}{2}$ in.; bark not blistery

$c c$-Needles sticking out all round twig

$d$-Needles $\frac{1}{2}$ in. or so long

$e$-Needles in whorls of three, sharppointed

$e e$-Needles not whorled; not sharppointed

$d d$-Needles less than $\frac{1}{2}$ in. long, sharp-pointed

$e$-A spreading shrub

$e e-$ A pyramidal shrub or tree

White Pine

Jack Pine

Balsam (Parks)

Hemlock

Common Juniper

Spruce (Parks)

Creeping Juniper Red Cedar or Juniper

AA. Trees not cone-bearing; leaves not needle-like but broader, falling in autumn

$a$-Leaves and twigs two or more at node

$b$-Most leaves (and leaf scars) three at node

$b b$-Leaves (and twigs) two at node, opposite

$c$-Leaves compound

$d$-Palmately compound; buds large, gummy

$d d$-Pinnately compound

Catalpa

$e$-Twigs slender; leaf scars encircling

twig and meeting in a point

Box Elder or Ash-leaved Maple

$c e$-Twigs coarse; leaf scars not meeting

$f$-Twigs square

$g$-In swamps; fruit wing tapering

at both ends

Water Ash

$g g$-In rich woods; fruit wing blunt both ends

Horse Chestnut

Blue Ash

$f f$-Twigs round

$g$-Branchlets downy

Red Ash 
g -Branchlets smooth

$h$-Leaflets without stalk, buds black

Black Ash

$h h$-Leaflets with stalk

$i$-Leaf scar concave on upper margin; leaflets pale below

ii-Leaf scar not concave; leaflets bright green both sides

White Ash

$c c$-Leaves simple

$d$-Lobed

$e$-Leaf scars encircling twig, meeting in point

Norway Maple (Parks)

$e e$ - Leaf scars not encircling twigs

$f$-Cleft between main lobes of leaf $U$-shaped; marginal teeth few

Sugar Maple

$f f$-Cleft between main lobes $V$-shaped; marginal teeth many

$g$-Leaf very deeply cut; twigs green

gg-Leaf not deeply cut; twigs red

$d d$-Leaves not lobed; pith streaked with red

Green Ash

\section{red}

Flowering Dogwood

$a a$-Leaves only one at node, alternate

$b$-Leaves compound

$c$-Leaf with three leaflets

$c c$-Leaf with more than three leaflets

Hop Tree

$d$-Twigs very stout, pithy

$e-$ Bark with diamond-shaped areas ap-

pearing as if made by pasting on strips of paper; pith salmon

Kentucky Coffee Tree

$e e-$ Bark not showing conspicuous diamondshaped areas

$f$-Leaf scars large, triangular; pith chocolate-brown

Soft Maple

Red Maple

$f f$-Leaf scars V-shaped; pith yellow-

Ailanthus brown

$g$-Twigs velvety

gg-Twigs smooth

$d d$-Twigs not very stout

Staghorn Sumac

Smooth Sumac

$e$-Leaflets mostly broad at outer end, oblanceolate

$f$-Bark shaggy, with detaching flakes Shagbark Hickory

$f f-$ Bark not shaggy

$g$-Leaflets $5-7$; nut thick-shelled

Pignut Hickory 


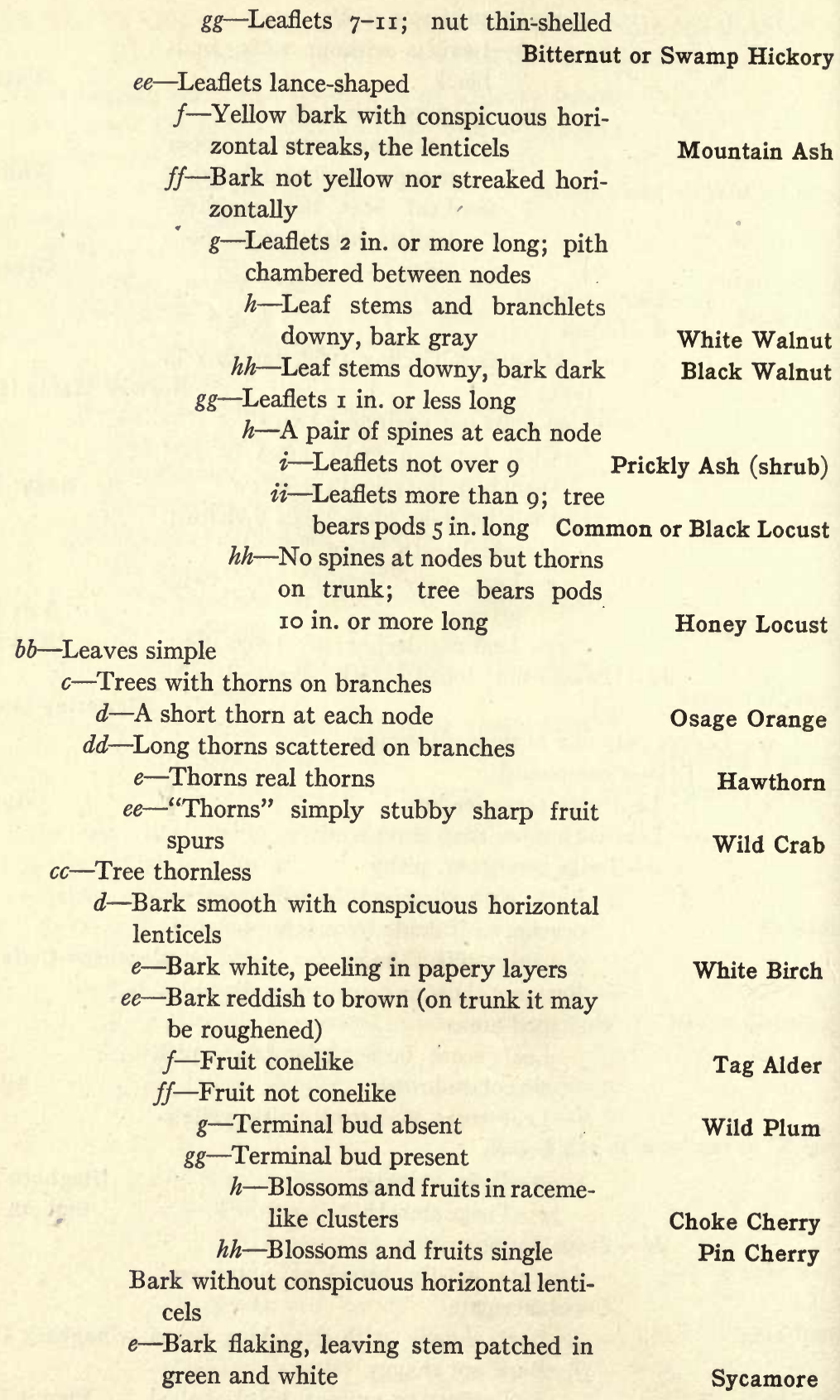


$e e$-Bark of trunk or of twigs with high corky ridges

$f$-Corky ridges on main trunk; leafbase oblique

Hackberry

$f f$-Corky ridges on twigs

$g$-Leaves lobed

gg-Leaves not lobed

eee-Bark like alligator skin, twigs aromatic

Sweet Gum

Cork Elm

Black Cherry

eeee-Bark green on limbs, and in young trees also on main trunk

$f$-Leaves broad, as wide or nearly as wide as long

g-Undersurface of leaves silvery white with hairs

$h$-Leaf stem flattened from side to side

White Poplar

$h h$-Leaf stem square or channeled, not flat

Downy Poplar

$g g$-Undersurface of leaves not silvery

$h$-Leaf stem flattened from side to side

$i$-Branches ascending close to trunk Lombardy Poplar

ii-Branches spreading

$j$-Leaves cut off square at base, taper-pointed

Carolina Poplar or Cottonwood

$j j$-Leaves broadly ovate

$k$-Marginal teeth coarse

\section{$k k-$ Marginal teeth fine}

Large-toothed Aspen Poplar

$h h$-Leaf stem not flattened, channeled

Small-toothed Aspen Poplar

$i$-Leaf hairy below

Balm of Gilead

ii-Leaf smooth but silvery below

Balsam Poplar

$f f$-Leaves narrow, not nearly as wide as long

(willows, Syrticola)

$g$-Leaves smooth or nearly so on both sides when mature

$h$-Leaves ten times as long as wide (shrub) Long-leaved Willow (S. longifolia)

$h h$-Leaves broader, lanceolate to ovate $i-$ Branches drooping 
$i i-$ Branches ascending

$j$-Shrubs or low trees less than $20 \mathrm{ft}$. high

$k$-Twigs purplish

Purple Willow ( $S$. purpurea)

$k k$-Twigs brownish or yellowish

$l$-Petioles and stipules glandular

$m$-Leaves shiny, green both sur-

faces

Shining Willow (S. lucida)

$m m$-Leaves shiny, pale below

Autumn Willow ( $S$. serrissima)

$l l$-Petioles and stipules not glandular

$m$-Leaves entire, elliptic; I-3 ft.

- $m$ m-Leaves more or less toothed

S. pedicillaris

$n$-Leaves not white below

$o$-Leaves dull green above

S. cordata

oo-Leaves glossy above

Shiny-leaved Willow ( $S$. glaucophylla)

$n n$-Leaves white below

$o$-Leaves elliptic to ovate,

the fine teeth glandular

Balsam Willow (S. balsamifera)

oo-Leaves lanceolate to oblong

$p$-Young leaves densely silky

Silky Willow (S. sericea)

$p p$-Young leaves only

slightly hairy

$q$-Leaves lanceolate, taper-pointed

S. petiolaris

- $q q$-Leaves oblong-

lanceolate, acute

Glaucous Willow (S. discolor)

$j j$-Trees $20-70 \mathrm{ft}$. high

$k$-Leaves narrowly lance-shaped, six times as long as wide Black Willow (S. nigra)

$k k$-Leaves broadly lance-shaped, less than six times as long as wide

$l$-Pale beneath

Peach-leaved Willow (S. amygdaloides)

$l l$-Same green both sides

Fragile Willow (S. fragilis)

$g g$-Leaves persistently hairy, at least below 
$h$-Cultivated trees

$i$-Leaves finely serrate

White Willow (S. alba)

$i i$-Leaves entire

Osier Willow (S. viminalis)

$h h$-Native shrubs

$j$-Low, I-6 ft. high

$k$-Leaves 2 inches or

less; $\mathrm{I}-2 \mathrm{ft}$.

Dwarf Gray Willow (S. tristis)

$k k$-Leaves 2 inches or more long; 2-6 ft.

$l$-Leaves and young twigs white, hairy beneath

Hoary Willow (S. candida) $l l$-Leaves gray, hairy beneath

Prairie Willow (S. humilis)

$j j$-Tall shrubs, $5-\mathrm{I} 2 \mathrm{ft}$.

high

$k$-Leaves hairy both sides

S. syrticola

$k k$-Leaves hairy only below

$l$-Leaves narrowly lanceolate, silky, shiny, below Silky Willow (S. scricea)

$l l$-Leaves broadly lanceolate, white, hairy below

Dwarf Gray Willow (S. rostrata) eeeee-Bark with none of foregoing characters $f$-Leaves lobed (except shingle oak) $g$-Bearing apples

Hawthorn (Cralaegus)

$g g$-Bearing acorns

Oaks (Quercus)

$h$-Leaves with rounded lobes, not bristle-tipped

$i$-Leaf broadest across middle; acorn long, $\frac{1}{3}$ in cup

White Oak (Quercus alba)

$i i$-Leaf broadest at outer end

$j$-Acorn short-stalked, $\frac{3}{4}$ in fringed cup

$j j$-Acorn, long-stalked, $\frac{1}{2}$ in

Bur Oak (Q. macrocarpa)

cup

Swamp White Oak (Q. bicolor)

$h h$-Leaves with acute lobes,

bristle-pointed when young 
$i$-Leaves deeply pinnately lobed

$j$-Longest lobes about equaling widest middle portion

$j j$-Longest lobes two to six times widest middle portion

$k$-Scales of cup not sticking out

$l$-Acorn globose, cup shallow

$l l$-Acorn ovoid, cup covers about half $m$-Interior bark red

$m m$-Interior bark yellow

Northern Pin Oak (Q. ellipsoidalis)

$k k$-Scales of cup sticking out

ii-Leaves entire lanceolate

$f f$-Leaves not lobed

$g$-Leaves spreading out on opposite sides of twig appearing tworanked

$h$-Sap milky

$h h$-Sap not milky

$i$-Bark smooth; trunk fluted ii-Bark rough

$j$-Leaves oblique at base;

bark coarsely furrowed

$k$-Leaves large, nearly as broad as long

$k k$-Leaves not nearly as broad as long

$l$-Leaves very rough; branchlets and buds downy

ll-Leaves smooth; branchlets and buds smooth

$j j$-Leaf base not oblique

$k$-Bark smooth, gray

$k k$-Bark finely furrowed
Red Oak (Q.rubra)

Pin Oak (Q. palustris)

Scarlet Oak ( $Q$. coccinea)
Laurel Oak (Q. imbricaria)

Black Oak (Q. velutina) Laurel Oak (Q. imbricaria)

Mulberry

Hop Hornbeam

Basswood

Red Elm

White Elm

Beech

Ironwood 


$g g$-I.eaves not apparently two-ranked

$h$-Leaves obovate (Fig. 3e)

Pawpaw

$h h$-Leaves not obovate

$i$-Margins entire

$j$-Leaves heart-shaped

Red Bud

$j j$-Leaves lanceolate

Laurel Oak

ii-Margins toothed

$j$-Double-toothed

Hazelnut

$j j$-Single-toothed

June Berry

Tree nursery.-Grow seedlings of the oak, maple, linden, apple, cherry, quince, and plum or of any other desirable shade or fruit trees. This work may be started indoors in the winter, the seedlings kept in the pots until late in the spring and transplanted to the school garden, later to be used on the school grounds or on the home grounds of pupils. Fruit trees raised from seed usually produce inferior fruit. There is a strong tendency for such trees to revert to the wild types. Hence it is customary to cut back such trees and graft on desirable stock. Look up the method of grafting. Write out the directions on the blank sheet opposite and try out the process on some of the year-old trees planted the preceding year. Observe the method used in pruning shade trees in parks or along the streets. Observe the method of pruning in the orchards near by. State briefly what you find out as to the proper method of pruning. How should a grapevine be pruned so it will bear well? Find out how to prune blackberries, raspberries, currants.

Common shrubs.-Learn to know the following shrubs. Consult Apgar's Shrubs of the United States.

Aralia spinosa: Hercules club

Berberii thunbergii: barberry

Cephalanthus occidentalis: button bush

Cornus stolonifera: red osier dogwood

Corylus americanus: hazelnut

Diervilla lonicera: bush honeysuckle

Euvonymus atropurpureus: wahoo or burning bush

Juniperus communis: common juniper

Juniperus horizontalis: prostrate juniper

Lonicera sullivanii: bush honeysuckle

Physocarpus opulifolius: ninebark

Rosa blanda: smooth or meadow rose

Sambacus canadensis: common alder

Sambacus racemosa: red-berried alder

Symphocarpus racemosus: snowberry

Syringa vulgaris: lilac 
Tamarix indica: Tamarix

Taxus canadensis: American yew

Viburnum lentago: black haw

Viburnum opulus: cranberry tree

Zanthoxylum americanum: prickly ash

Propagation.-Shrubs are usually propagated by cuttings. In early spring cut off a six-inch length from the end of a lilac, syringa, or raspberry twig. Remove all buds except the terminal ones. Stick this in moist sand and keep it where the temperature is not very high. Keep the sand moist, not wet. In time the stem throws out rootlets and the leaf buds develop. The new plant may now be set out in the garden. When the shrubbery is pruned, in late winter, the twigs that are cut off may be kept to use for cuttings. Cut them up into from four- to six-inch lengths with a bud on each. Tie them up in bundles and keep in a cool cellar or bury until spring, when they are set in the sandy soil in the garden until roots and new shoots form. The soil should contain little organic matter. The school garden may well contain a bed devoted to rearing trees and shrubs. The seeds and cuttings can be obtained free of charge and the school grounds or even the entire neighborhood be benefited.

Tree distribution.-Make a trip to some river valley bordered by hills or to the shore of a large lake or ocean to note what sorts of trees and shrubs are growing in the region. List the trees that you find growing chiefly in the sandy soil, on the rocky hillsides, in the swamps, and on the river bottom. As a result of your study make a diagram of the region studied and indicate the names of the characteristic trees and shrubs of the several localities.

Lumbering.--Read up on the lumbering operations and write out on the following blank page the history of a tree from the time it is cut until it is in furniture. Answer these questions on the blank pages following: (I) How much of the tree is left in the forest as waste? (2) What is usually done with the trimmings? (3) How should they be handled? (4) How much of the tree trunk is turned into lumber? (5) What becomes of the rough exterior? (6) How is the lumber dried? (7) How is the quartersawed lumber produced? (8) What is veneer and how is it cut? (9) In taking trees out for lumber which should be cut and which left? (Io) If the trees in an area to be lumbered are all mature should all be cut? (II) What was the estimated forest area for the United States when the first settlers came to this country? (I2) What is it now? (I3) How much of the general timberland is held by the government? (14) How much is held by states? (I5) How much does your state own? (I6) How much is held by large landholders? (I7) How much is held by farmers? (I8) How 






much wood do we use up annually in the United States per capita? (19) What is the per capita consumption of France? (20) Of Germany? (2I) Of Italy? (22) What is the proportion between what we grow and what we use? (23) What is the average annual loss in the United States due to forest fires? (24) What are the chief causes of forest fires in order of their importance? (25) In the hill countries what happens to the soil of a burned-over area? (26) Do the same trees usually grow in a burnedover area as stood on the ground before the fire? (27) What area do we have in the United States good for nothing but growing forests? (28) How much of this is now forest-covered? (29) What is the average area that we plant annually? (30) How much of this is planted with young trees? (3I) How much with seed?

Lumber.-Learn to know the following dressed lumber: white pine, Georgia pine, spruce, hemlock, red wood, red cedar, cypress, white wood, hard maple, bird's-eye maple, birch, ash, hickory, oak, walnut, and mahogany. Examine the furniture and woodwork about the school and the home. Can you tell of what woods it is made? 


\section{THE SPORE-BEARERS}

Molds. - Let a piece of moist bread stand in an uncovered pint jar for two or three days, adding water occasionally to keep it moist. Then cover the jar and watch for mold to appear. Probably either the common black mold or the green mold will develop. The bread rapidly becomes covered with a tangle of delicate interlacing colorless threads known as the hyphae, the entire mass being designated as the mycelium. Soon some of the upright hyphae of the black mold grow the spore cases at their tips; the green mold shows the clustered chains of spores. The spore cases rupture and discharge the spores, tiny particles that dust off, germinate on the moist surface of the bread and start new mold plants. Examine some of these spores, if possible under a hand lens, or, better, under a microscope. Not much is to be seen on casual examination, but you will be impressed with their minute size and great abundance. These spores are not structurally like seeds. The seed contains the young plant, which simply becomes larger when the seed is planted. These spores are single cells, which grow into new plants under favorable conditions.

Toadstools. - There are a great many more plants that reproduce by spores than there are plants that bear seeds. Familiar examples are the puff balls and toadstools, the lichens, mosses, ferns, and horsetails. The toadstool is really only the spore-bearing part of the plant; the bulk of the plant, the mycelium, is buried in the decomposing organic matter in the ground or the rotting log on which the toadstool appears. Examine some toadstool and note its parts, the stem and cap, the latter having on its under side many spore-bearing gills or numerous tubes from which spores discharge. Try to find some of the buried mycelium. Cut off the cap and lay it down, top up, on a sheet of white paper, covering it with an inverted tumbler or bowl. Let it stand for a couple of days, during which time spores discharge, forming a very pretty "spore print" on the paper. If moist gum paper is used the spores adhere to it and the "print" is permanent. Spores from different kinds of toadstools are often of different colors-blues, yellows, reds, black - so that a variety of colored patterns may be obtained.

Look on the trunks of trees for the oyster-shell fungus and the bracket fungus. The mycelium of these grows in the wood as it decays and the part seen on the trunk is merely the spore-bearing portion. Break one 


open to see the tubes which contain the spores. How do such fungi get established on the tree? What could be done to prevent their attack?

The moss plant.-Study some moss plant like the hairy cap (Polytrichium). Note (I) the holdfasts in the soil, (2) the leafy upright stem, and on top of this, at some seasons, (3) the spore-bearing part consisting of (a) a stalk whose base is held in the top of the leafy stem, and (b) a spore case; the latter is protected in this particular moss by the hairy cap. When the spores are ripe they shake out like pepper from a pepper shaker. The perforations on top of the spore case sometimes make a characteristic and beautiful pattern.

Fern spores.-The spore cases on the fern are found in rows or clusters on the back of the fern frond, as in the rock polypody, or else one or more of the leaves is given up partially or entirely to the production of spores (Clayton's fern or the cinnamon fern). Lay a fern frond with welldeveloped spore cases, back down, on a sheet of white paper. The spores soon fall off. It is interesting to sow these on the surface of moist and wellfirmed soil in a pot which is kept covered with a plate of glass. The spore develops into a somewhat leaflike heart-shaped structure (the prothallium) that grows flat on the soil and sends down its holdfasts. It is only as large as the end of a pencil or smaller. From this the new fern plant grows. Such prothallia may often be found on the pots or benches in the greenhouse, where the florist has ferns growing, or on the moist soil in the woods where ferns are abundant.

Horsetails. - In the horsetail the spores are grown in a cone-shaped structure at the end of the stem. The horsetails or Equisetae are also known as snake grass or as joint grass, because the stems break apart so easily into hollow segments. One of the common ones often grows along railroad embankments or in waste fields. The stems are very harsh to the touch, containing much silica, and they are used, when tied in bundles, to scour pans by frontier settlers. Hence the name "scouring rush" is commonly given to the plant.

Sterilization.-Rig up a steam sterilizer as follows: Take two lard pails or other similar covered pails that will set one inside the other, leaving a three- or four-inch space between bottoms. Punch holes in the bottom and one or two in the top of the inside pail. Put water in the outer pail so that when boiled the steam will escape through the inner pail. Put a piece of moist bread in a clean pint fruit jar. Set the cover on but do not screw it down. Put this in the sterilizer and steam for twenty minutes. Let it stand twenty-four hours and again steam twenty minutes. Screw the cover down and let it stand. Does mold appear on the bread? What does this show? Shove a needle into a wood handle about the size of a pencil. 
Heat the needle in a flame to kill any spores that might be on it. Then draw the needle through the spore-bearing black mold or the green mold, trying to get spores of one kind only on it. Open the jar containing the sterilized bread and quickly draw the needle across the surface of the bread. Do not leave the jar open longer than is necessary. When it is closed tightly again let it stand a few days. Where does mold begin to appear on the bread? What kind is it? What is your conclusion? What is essential that any process of sterilization be effective?

Useful fungi.- The molds and other fungi are among man's most useful allies, although some of them are also injurious. The soil, especially rich soil like that of the forest, is full of them, and they decompose the organic matter and reduce it to substances that plants can use for food once more. The very numerous hyphal threads come in contact with the roots and help them to get in touch with adequate supplies of moisture and nutrition. Examine rich garden soil or humus from the woods to see if you can detect these molds.

Yeast.-One sort of yeast is used constantly in bread-making and other kinds are used in the manufacture of beer, cheese, etc. The compressed yeast cake is just a mass of these yeast plants with more or less starch and other foreign matter. What is its color? The dried yeast cake is the same; dried out. Put a quarter of a yeast cake into a half-cup of molasses or sugar syrup in a flask or bottle and let it stand in a warm place until it ferments. The sugar is being used in part by the growing yeast plants for food, but certain wastes are given off. One is alcohol, the odor of which is readily detected. Another may be demonstrated by fitting the mouth of the bottle or flask with a cork from which a delivery tube passes into a test tube filled with limewater. What is the result and what process does this show is going on in the growing yeast? Why does the yeast have to be provided with organic food like sugar?

Bacteria.-Many more of the plants most significant to man are exceedingly tiny. Such are the bacteria, some of which are very useful, like the nitrifying bacteria on the roots of the leguminous plants or those that live in the human intestines and help with the digestive processes, while others are injurious, such as those that cause tuberculosis. Draw a circle three inches in diameter to represent the cross-section of a human hair. Hairs vary in diameter, some persons having very coarse, others very fine, hair, but one four-hundredths of an inch would be an average diameter. A dot with a sharp pencil will represent the diameter of a tubercle bacillus and a line one-eighth inch long its length on the same scale.

Rate of reproduction.-Such bacteria are too small to be seen except under very powerful microscopes, but they multiply rapidly by repeated 


division so that they form colonies that are readily visible, and these usually have a characteristic color, shape, or other peculiarity. Bacteria are capable of such rapid reproduction that it is calculated that one of them growing without check would develop a mass of them as big as the earth in a week's time.

Cultures.-Very thoroughly clean six test tubes and two petrie dishes or four saucers, two large and two small. Obtain some grape gelatin, the sort that is sold at the grocery stores for puddings. Melt it according to directions as if preparing it for pudding. Add a quarter-tablespoon (level) of soda to neutralize the acid and make it slightly alkaline. Most bacteria grow best in an alkaline medium. Fill the test tubes one-fourth full and plug them with absorbent cotton. Fill the bottoms of the petrie dishes or the two small saucers, covering the dishes with their covers or the saucers each with an inverted large saucer. Put these all in the sterilizer and steam twenty minutes. Then cool, standing the test tubes in a much-inclined position so that the gelatin will set'at a slant from near the mouth of the test tube to near the bottom on the other side:

Planting bacteria.-Catch a fly and let him crawl around on the gelatin in one slant tube, then release him, replugging the tube. Label it so that you will know which one was used for this experiment. With a toothpick scrape the teeth and smear the scrapings on the gelatin surface in another slant tube, then plug it again and label. Leave one of the slant tubes open in the schoolroom for fifteen minutes before school and another for fifteen minutes near the close of the session. Plug each at the end of the time and label. The sixth tube will be left just as it came from the sterilizer for comparison.

Let some pupil with rather dirty fingers press his thumb on the gelatin in one of the saucers (or petrie dishes). Cover it immediately; then let him wash his hands well and come and press the same thumb on the gelatin in the same saucer but on a different spot; cover promptly. The second saucer will be left as it came from the sterilizer. Set these all aside where they can be at least at room temperature. Examine daily to see if colonies of bacteria appear. Each spot is a colony and the number of spots that appear will give some idea of the number of bacteria or mold spores that were deposited on the surface of the gelatin. 


\section{ANIMAL COMPANIONS}

In this work it is imperative to have the animals themselves in the schoolroom for observation. The cat and dog may be brought daily by some pupil. The squirrel and rabbit may be kept in the schoolroom for a few weeks during observation. A cage may be improvised from a large box and some inch-mesh galvanized wire netting. Do not use the wire mosquito bar for cages. Animals will gnaw off the paint with which it is coated, with disastrous results. Sawdust or dry earth spread on the bottom of the cage will add to the animal's comfort. A pan of drinking water should be provided. Feed rabbits and squirrels on dry foods-corn, oats, bread crusts, nuts for the squirrel, and an occasional bit of lettuce or grass or other green stuff. This avoids offensive odors. Keep the cage clean.

\section{The cat and dog.-}

Feeding. - It is well to have more than one cat to observe, as puss is likely to be more or less stagestruck and refuse to eat in the presence of so many spectators. Have ready for this lesson two or three bones with a little meat upon them, as pork or mutton chops. Now give the cat a bone and gather about quietly to watch her eat. While she is cleaning the bone answer the following questions to bring out significant points: Does she eat at once or does she sniff at the food and take a little time to inspect it before she begins to eat? Does she try to run off with the food? If so, where does she go to eat it? How does she hold the bone while she eats? Does she use her claws to hold it? Does she stand up or lie down while eating? Does she eat hurriedly or slowly? Does it disturb her to have you move around while she eats? Does she bite off the meat as you would bite it off a bone or as you would bite corn off a cob? What teeth does she use? Could you use the same teeth to bite with? Does a cat chew her food well? Why does she lick the bone? When she licks your hand does her tongue feel soft and smooth, like your own? Give a cat a few loose bits of meat or scraps of other food. Does she seize them quickly or deliberately? Does she stop to chew them well? Bring in a second cat while the first one is feeding. Watch their behavior. Give the second cat some scraps to eat near where the first one is feeding. What follows?

Provide a bone and some scraps of food. Have someone bring a dog to school. Be sure that it is hungry, then feed it while it is being watched. The same series of questions used for the cat may form the outline for the 


study of the dog's feeding. It will be unwise, however, to bring in a second dog unless there is an abundance for both.

Drinking.-After he has eaten give the dog a drink. How does he get the water? Watch to see the shape of his tongue as he laps it. Let someone go to the board to draw the shape. Watch to see how the cat drinks milk. Does a horse drink as a dog does? How does a cow drink?

\section{Squirrels and rabbits.-}

Feeding.-For this lesson have the squirrels and rabbits in the schoolroom. It is wise to cover the entire outside of the box that you use as a cage, and not the open side only, with the inch-mesh galvanized-wire netting or else protect vulnerable points with strips of tin. These animals are rodents and will gnaw their way to freedom and mischief in the schoolroom if opportunity offers.

Watch the rabbits and squirrels eat. How does the squirrel hold the nut? Does he crack it as you would crack a nut? What teeth does he use? What is their shape? Does he chew the nut well? Does he eat the nut where you give it to him or does he run off to some other part of the cage to eat it? What position does he take while he is eating? After he has eaten all he needs what does he do with other nuts you give him? Compare the rabbit's method of eating with that of the squirrel. Can the rabbit hold food in its forepaws when it eats? Can you?

Drinking. - Take the pan of drinking water out of the cage and leave it out for several hours so that the animals will be sure to be thirsty. Then put in fresh water and observe the method of drinking. Compare with the dog and horse. From your observations do you think that animals get hungry and thirsty as we do? This will afford an appropriate opportunity for simple directions on the care of pets.

Perchance this work as outlined appears so commonplace that it will seem to some an unnecessary expenditure of valuable time on what is not only familiar but also insignificant. But a careful study of these familiar matters will convince one that what is so commonplace is not always therefore well known. Moreover, there is more of significance in these observations than one might at first think. There is a volume of ancestral history revealed in some of these apparently trifling mannerisms. The cat, for instance, you will find sniffs daintily of her food, eats leisurely, and prefers to have her meal in seclusion. The dog bolts his food with all possible celerity, growling meanwhile at any possible interference and yet not seeming to be greatly disturbed by onlookers. One can see at once the inherited traits outcropping. The cat has always been a solitary hunter. Her ancestors did not hunt together, as the dog tribe has usually done. The members of the great cat family are accustomed through generations of 
usage quietly to partake of the prey which they have hunted alone and killed in the solitude of the forest or jungle. Not so the dog tribe. They have hunted in packs, and when the kill was at last accomplished each animal seized his share, eating amid a jostling crowd of hungry fellows. Each secured the choicest morsel possible and defended it against all comers. Yet each was anxious to stow a large share of the plunder in the shortest time in that one spot secure from the claims of disputants.

This has not been suggested with the expectation that so much of philosophizing will be attempted with pupils of the lower grades, but merely to give the teacher an inkling of what may be disclosed by the observations we are now making.

Methods of motion.-Watch a cat move from place to place. Does she walk? Does she run? Does she go in any other way? Note particularly the crouching attitude assumed by the cat as she intently watches a moving object; then see the few quick bounds with which she reaches it. Try putting the cat on a post or tree trunk and watch her come down. Coax her to climb by holding a piece of meat or other food upon the tree just out of her reach. As she climbs have the children observe how she does it. Does pussy climb as a boy would climb a tree?

Now watch the dog as he runs about.' Does he walk, run, jump, or climb? How did you get the dog to come to school? Did his master just call him? Did puss follow her mistress to school or did she have to be carried? Watch the rabbit and squirrel to see how they move about. Does the rabbit walk or run like a dog? Watch the squirrel climb and note whether he does it as a cat climbs. Watch the squirrels and chipmunks in the woods and see what they are busy doing these days.

Cleanliness.- Let the cat have some milk to drink or a bone to gnaw and after she has finished watch her at her toilet. She usually cleans herself after feeding. How does she use her tongue in the process? What use does she make of her paws? Does she ever go in for a swim? Does the dog like to go in the water? Do you give your dog a chance to take a bath? Watch the squirrel and rabbit as they wash and clean their fur. During the week when this topic of cleanliness is being studied it will be well, whenever the squirrels or rabbits are cleaning their faces, to take time to watch them, as this process cannot be produced at will as feeding can.

Sleep.-Do dogs and cats sleep? rabbits and squirrels? What position does the cat take when she sleeps? Where does she like best to go to sleep? Where does the dog prefer to sleep? What position does he take when asleep? What motions does he usually make before he lies down? Does the cat sleep much in the daytime? Does the dog? Have you a good 


bed for your dog? The animal's bed should frequently be renewed, for old straw that it may sleep upon readily accumulates vermin. If the dog sleeps in a kennel, as it should, this should be whitewashed inside at least twice a year. It is important to keep the quarters that animals occupy in sanitary condition, not alone for the sake of their comfort, but because when we make them our companions it is a source of danger to us if they are diseased.

What becomes of the squirrels in the winter time? Do dogs like to be out of doors in the snow? Do cats? Will your dog run through the deep snow and frolic with you? Will the cat? Are rabbits out in the winter time? What do they feed on then?

Senses.- Hide a piece of meat in the schoolroom within easy reach and let in a hungry cat. How long does it take her to find the meat? Make a similar test at home. When the regular feeding time for the cat comes let her see you with a saucer of milk and then hide it while someone holds her and see how long it will take her to find it. Try a dog in the schoolroom in the same way and see if he can find the meat as quickly as the cat did. Do not make the task too difficult, but place the meat where it can easily be found, hiding it in the same place for the cat and the dog. Which do you find has the keener sense of smell, a dog or a cat?

Place the cat at one end of the room and roll a rubber ball across to the opposite end. Make as little noise as possible in rolling it and let everyone keep very still so as not to distract puss's attention. Does she catch sight of the ball quickly? Make the same test with the dog. Does he see the moving object as quickly? Which can see farthest, a dog or a cat? Devise and try some tests out of doors and at home, with cats and dogs, to answer this question.

Stand the length of the schoolroom away from the rabbit cage and make some unusual sound like a low whistle. Do the rabbits prick up their ears and stare in your direction? Stand at the same distance from the squirrel cage and make the same noise, as loud as before. Do the squirrels hear it? Repeat the test for rabbits and squirrels, varying the intensity of the sound until you can decide which has the keener hearing.

It is probable that you will not have time for testing more than a single sense. It is better to repeat one test until satisfied that the results are trustworthy than to attempt several. More than one test is suggested that choice may be exercised to suit the convenience of the teacher. This experimental work marks a step in advance of simple observation. The method of presentation is important. State the question to be settled to the pupils. Be sure that they understand it. Lead them by appropriate questions to suggest the test that is to be made. Assure yourself that they understand 
what is being done and what it is done for. Secure from them at the close of the work a statement of the experiment and its result.

Uses.-Tell what you can of the uses of the cat, dog, cow, horse, rabbit, and squirrel. What service do the St. Bernard and Eskimo dogs render?

The following are a few suggestions of sources of good stories: Nesbitt's Pussy and Doggy Tales, Houliston's Cat Tails and Other Tales, De la Ramée's Dog of Flanders, Mother Goose Rhymes. Old files of the Youth's Companion and St. Nicholas will afford good stories of these animals. Many of the child's poems of animal life have been set to music and may appropriately be used in connection with the nature-study. Mother Goose Melodies, published by McLaughlin Brothers, contains "Pussy Cat, Pussy Cat," "Poor Dog Bright," "I Had a Little Doggy," and others. Equally good songs may be found in any standard collection suited to the lower grades.

Familiarize yourself with some of the good animal pictures and their artists. The following are suggestions: Adam's "Kittens," Landseer's "Dignity and Impudence," Holmes's "Kiss Me," Troyon's "Oxen Going to Work," Bonheur's "Cattle of Brittany" and "Horse Fair."

Need of protection. -Need a squirrel be afraid of a cow? of a cat? of a dog? of a rabbit? Why? (Recall food and feeding habits already studied.) Need a cat be afraid of a squirrel? of a dog? of a cow? Need a dog fear a horse? Need a wolf fear a horse? a cow? Why? It is presumed that many of this series of questions will be answered from the observations that pupils have made.

Need a dog be afraid of another dog? a cat of another cat? Have you ever seen squirrels or rabbits or horses fight? Such questions make clear the fact that animals frequently need protection from others of the same kind quite as much as from their mutual enemies.

Why does not a rabbit freeze in the winter? Have you ever found a dead bird? What do you think killed it? Have you ever found other wild animals dead, such as squirrels, field mice, frogs, etc.? As a result of such questions it will be shown how essential it is that animals be protected from adverse physical conditions, such as cold, rain, and storms. It is well for the child to realize, not how strenuous the struggle for existence is among the animals afield, but that it is strenuous. It will lead to many kindly acts. Crumbs thrown out at the door, a handful of corn deposited weekly in the same spot, a few nuts left always on the same stump, a crust of bread left every few days in the same place in the woods will not only help develop a thoughtful care for the unfortunate, but it will acquaint the child with the many unfamiliar birds that will come to his dooryard for food. It will give him autographical sketches, unconsciously written in the tracks in sand or snow, about the spot he may choose for his beneficence. 


Where do the wild rabbits live? Where do the squirrels live? What other familiar animals live in holes, in trees, or in the earth? Where are the homes of chipmunks, gophers, ground hogs, and muskrats, and what are their habits? Perhaps something can be learned of the structure of these houses and their uses as storehouses for food as well as places of retreat. Ernest Ingersoll's Wild Life of Orchard and Field has some fascinating chapters on these common rodents and their homes.

Means of protection.-When do cats, dogs, and horses shed their hair and why do they do it? When do they need their heaviest coat? Where do the animals with very thick fur live? What are some of the animals whose fur man uses?

When a dog chases a cat how does she defend herself? (See Ernest Thompson Seton's Johnny Bear.) If a dog should run after a squirrel how could the squirrel protect itself ? Could a cat escape from a dog by flight? Could a rabbit run away from a dog? Could it defend itself against a dog? How would it escape harm? Could a horse run away from a troublesome dog? How could a horse protect itself from a dog in a way other than by flight?

In answering the foregoing questions probably horns, hoofs, teeth, and claws will be mentioned as weapons of defense. Name other animals besides those mentioned above that use claws, or teeth, or hoofs, or horns for defense. Can you think of any other defensive structures besides horns, hoofs, teeth, and claws? Do all the deer have horns? Which sheep have horns? Why do roosters have spurs when the hens have none? Can you think of other animals in which the males are especially armed with means of defense? Tell the story of the fight of the male to defend the young or the females. Such stories are to be found in Roberts' Heart of the Ancient Wood, chapter viii, "Red Dog" in Kipling's Second Jungle Book, "Lobo" in Thompson Seton's Wild Animals I Have Known. Some effective pictures to show just at this point are Landseer's "Deer Pass," "The Combat," and Thompson Seton's "Krag, the Kootenay Ram." Make emphatic this especial adaptation of the male to protect the weaker females and the unprotected young. Lead the children to admire his reckless expenditure of strength and even of life in so doing. The natural pugnacity of the boy may be directed toward gallantry and the protection of the weak. This fighting instinct that sooner or later possesses every normal lad needs not repression but encouragement and proper guidance.

The sense organs as protectors.-The keenness of the animal's senses plays an important part in its protection. That animal escapes detection whose sharp eye, quick ear, and sensitive nose give it warning while the source of danger is yet a great way off. Recall the results of tests suggested 
in previous lessons to determine which of these common pets has the sharpest sight, the most acute smell, and the finest sense of hearing.

Compare the eye of the cat with that of the other animals we are studying. How does it differ from theirs? Do lions and tigers have pupils of the same shape? What other animals have such slit-shaped pupils? This form of pupil permits of very wide expansion and the animals that possess it are usually night prowlers, seeking their prey under cover of darkness or the forest's gloom. When you shut puss in the cellar to catch a mouse do you have to put a lamp there too so that she can see? Does a dog like to be shut in the dark?

It is evident that these alert sense organs are important not alone to give adequate warning of enemies but also to assist in tracking and capturing the prey. Why is a dog used in hunting? When you play hide and seek with your dog how does he find you? Does he follow you, nose to the ground, or does he just run about looking for you? How does the hunter's dog find the game? The acute sense of smell of the noted St. Bernard dogs has saved the life of many a traveler. Look up the story of some hunt where the dog's tracking power has been important. A good one is to be found in the closing chapters of Charles G. D. Roberts' "Romance of Red Fox" in Outing for September, I905.

Man has largely lost his keen sense of smell because he uses it so little. It is said that savages, like the American Indians when the white man first came to this country, would track their prey or their enemies by the sense of smell. Now we use the sense of sight. Can you tell a rabbit's track? a squirrel's? Can you tell in which direction the dog is traveling from his tracks? Draw a dog's track. Can you tell from a rabbit's or squirrel's tracks which way the animal has gone? Read "How Bunny Writes His Autograph" in Gibson's Sharp Eyes.

Notice that a dog's nose is cold and moist. Try the following experiment and then see if you can tell why the dog's nose is wet. With a clean handkerchief wipe dry the surface of the tongue. Sprinkle a pinch of sugar on the dry surface and keep the mouth open. When is the sweet taste noticed? What other animals have moist noses? Do they have a keen sense of smell also? Notice the reading of the thermometer in the schoolroom. Then wrap a moist cloth about the bulb. In a few minutes note the reading again. Now can you tell why the dog's nose is cold?

Protective color and habits.-The animal's weapons and senses are not its only means of protection. What is the color of the wild hare in winter? what during the rest of the year? What is the purpose of this change of color? What is the color of the squirrels in your neighborhood? Where do they live? What is the color of the tree trunks? What is the color of 


the deer's coat? of the fawn's? Can you think of other animals of your own region that are protectively colored?

What is the color of a skunk? of a hornet? Some of these animals that have a sting or other adequate means of defense are brightly colored and therefore conspicuous. The bright color serves to advertise their disagreeable qualities. Some of the great cats illustrate well another phase of coloration. They are colored like their surroundings, not to save them from attack, but so they can creep up without detection and capture their prey. The lion inhabitant of the desert regions has a coat of sandy hue. The tiger, lurking among the reeds and rushes of the river's margin, is striped with alternate bands of yellow and black. The leopard, jaguar, and many other forest-inhabiting animals are mottled to match the sunlight and shadow on the forest floor.

Certain habits of these common pets, relics of their wild ancestry, are protective in their purpose. Do you ever see a number of dogs on the street together? Do cats run about in packs? If one dog starts to chase a cow what do other dogs that are near by do? How do wolves hunt? tigers? Read chapter xvii of Du Chaillu's Land of the Long Night. Which of the common domestic animals go in herds? Their wild relations do the same. Wolves will readily kill one cow, but when the herd stands together with lowered heads the circle of horns effectually resists the attack.

Besides the stories already mentioned the following are suggested: "Mother Wolf's Story," St. Nicholas, March, I903; Lion and Tiger Stories, republished from St. Nicholas, in book form, by the Century Company; Porter's Wild Beasts.

Structure of the leg.-All these animals have head, trunk, tail, and limbs. Do angleworms have these parts? Can you think of other animals that do not have them? of some that do? Note the parts of the leg of a cat, the upper leg, lower leg, foot, toes. Does the cat have joints as we do? Notice the parts of your own arm, upper arm, forearm, hand, and fingers. Does the dog have joints in its legs? How many are there in the foreleg? Are they similar to those of the cat's foreleg in number and position? Are they similar to your own joints at knuckles, wrist, and elbow? Compare the foreleg of the squirrel and rabbit. How many joints are there? Are they similar in position to those of the dog and cat? Make an outline sketch of a person's arm and then of the foreleg of each of these animals to show the number of joints and the parts between joints. Then reduce these sketches to straight-line diagrams in which the joints are represented by spaces and the structures between the joints by lines. Your own arm would be diagrammatically represented on p. 64 , Fig. 5 . 
The hind leg.-Notice the cat's hind leg. How many joints does it have? Feel it carefully and see. How do these joints compare in number and position with those of the foreleg? Study the hind leg of the dog, squirrel, and rabbit. Compare with that of the cat. Sketch the hind leg and reduce to diagrams in the same way as already described for the foreleg. Write a description of what you have observed regarding the structure of the fore and hind legs of these animals. To hold one set of facts in mind and compare it with another and still another and finally with a whole series - to see a fundamental unity underlying superficial differences is to take a step in advance of mere observation.

Vertebrates.-Feel of the cat and dog to gain an idea of the skeleton. Feel the vertebral column, extending from head to tip of tail. Do horses and cows have a backbone? Do we? What other animals that you know have a backbone? Feel the ribs and breastbone; then note that the head is a bony mass. Feel the shoulder blade that fastens the foreleg to

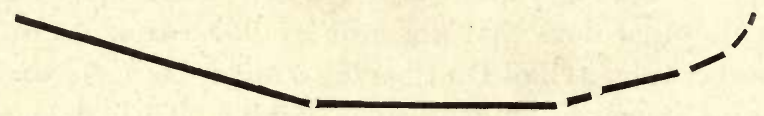

FIG. 5.-Diagram of forearm

the body. When the cat is not standing on her feet this bone, to which the foreleg is attached, may be easily moved about, as it is simply imbedded in the muscle, not fastened to the other bones. Demonstrate this to your own satisfaction. Feel the hip bone, to which the hind legs attach and which fastens, in turn, to the vertebral column. Are there bones in the legs? What is their relation to the joints that we have noted and diagrammed? Why does a cat have bones? Does an oyster have bones?

Is a cat's hind leg straight, like yours? How is the leg bent in the process of jumping? Try a jump and notice your movements. Now can you tell why the cat's hind leg is always bent? Watch the cat jump down from a table. How does she use the hind legs? On which legs does she alight? How does the way in which the foreleg is attached to the body make it easy for her to alight? How could the structure of the legs help the cat in hunting? Which has the straighter legs, a dog or a cat? Which can run faster? Think of other animals that can run fast and far. Do they have straight legs or legs bent like a cat's hind leg? Make a list of the very speedy animals and those vertebrates that do not run well. Note the length of the leg and the straightness of the leg.

Structure and use.-How many toes has the cat? dog? rabbit? pig? cow? horse? Why can puss walk so quietly? Feel the underside of her 


feet. Feel the dog's feet. Which are softer? Notice how the kitten uses her claws and how perfectly they are under her control. Where does she keep her claws when they are not in use? Can a dog sheath his claws? Which has sharper claws, a dog or a cat? Why? Recall how the cat and dog held the bone when gnawing it. How does the hoof serve a horse better than claws would? Dogs are used for hunting because they have a keen sense of smell (how did you prove it?) and because they can run swiftly and for a long time. Their relatives the wolves hunt in packs and run down very fleet-footed animals. The dog or wolf chasing its prey over rough ground needs what? The cat does not chase its prey, but, as we have seen before, creeps up stealthily and then pounces on it with a few powerful leaps. How is her structure well adapted to this? To what is the dog's straighter leg adapted? Does the rabbit's structure fit it for a long run or for a few quick leaps? What is the shape of a hound's body when seen from the front? of a squirrel's? What other animals have a deep, narrow body? Think of others whose body is round. Can you tell why a hound's body is narrow and deep, like a boat?

Continual care must be exercised by the teacher lest the nature-study degenerates into the observation of unimportant details. Thus merely to have children count the toes of cats, dogs, rabbits, squirrels, cows, and horses is scarcely worth while if the work stops there. Let this be but the first step in the discovery of the significant relations between form and length of leg, number and character of the toes, speed and endurance of the animal, and its habits of hunting or means of escape.

The head.-Compare the shape of the hound's head with the shape of the squirrel's. The former has a long, pointed head, the latter a compact, round one. Feel on your own face the point where the lower jaw hinges. This can readily be done as you open and close your mouth. Now feel the cheeks as you bite some hard object. You can notice the location of the strong muscles by which the mouth is shut, as they swell in action. These are the muscles that a squirrel uses as he chisels away the shell of a nut with the sharp front teeth. Think of the lower jaw as a lever, the fulcrum at the point where it hinges. The weight is the resistance to be overcome by the teeth in biting into an object. The power is applied by these jaw muscles we have felt. Draw a diagram of the long jaw of a hound and the short jaw of a squirrel, marking fulcrum, weight, and power on each. Take a stick, like a ruler; fasten one end by a single screw to a wall or table and attach a weight at the other end. Tie a string near the middle of the ruler; run this up over a pulley made by putting a small spool on a nail in the wall; attach weights to the free end of the string to balance the weight at the outer end of the ruler, thus holding the latter horizontal. The apparatus 
will roughly represent the arrangements of mechanical elements in the squirrel's jaw. Notice how much power is required to balance the weight attached at the end of the ruler. Now use a longer stick; have the weight at its end and the distance from the fulcrum to the point of attachment of the string about the same as before. Do you need more or less weight on the string to hold the stick horizontal ? Would it then be best for an animal that needed to bite hard to have a short jaw or a long jaw? What sort of a dog can bite hardest? Has he a long or short Jdw? Why does a hound have a long head? Compare a cat's teeth with those of a dog. Are they alike? Are they like your own? Are they like those of a horse or cow or sheep? How are the sharp, cutting teeth of the dog or cat well adapted to its methods of eating? What do you feed a horse or cow? Why do they have flat-crowned teeth? State the relation of the kind of teeth to the habits of the animal.

Note the position of the organs of special sense-eyes, ears, nose, tongue. Is there any advantage in having the sense organs on the head end? What is the use of a cat's whiskers?

Wild relatives.-We have seen that the cat is a warmth-loving creature. She loves to lie stretched before the fire and curls up to sleep in the warmest corner. She goes out regretfully in winter and then gingerly treads the snowy paths. From these observed peculiarities what would you infer regarding the probable habitat of the great cats-her wild relatives?

Endeavor to form clear mental pictures of the following wild relatives: fox, wolf, coyote, jackal, otocyon, bay cat, cheetah, fishing cat, jaguar, lynx, lion, manuel, ocelot, ounce, panther, puma, rusty cat, serval, tiger, wild cat, yaguarundi. Consult encyclopedias and natural histories to find descriptions of the appearance, habits, and haunts of these animals. Recall the work already done on protective colors of the great cats. Do any other of these animals besides those noted earlier illustrate the laws we there found?

Distribution.- Have each pupil draw an outline map of the world on a large sheet of paper ( 12 by 24 inches), or else use the printed outline maps. Indicate by initial letter ( $L$, lion, $L y$, lynx, etc.) on these maps the habitats of each great cat. Thus the tiger is found in Arabia, Persia, India, Siam, Borneo, Sumatra, Eastern China, Manchuria, and Eastern Siberia. In each of these localities put a $T$. Similarly mark the regions inhabited by the other great cats. A brief study of the map will enable you to discover some interesting facts. Can you state these and tell what you learn from them?

[NoTE.-The material of this chapter is graded so as to give the student-teacher an idea of how to adopt the subject-matter to the various grades, making it increasingly difficult as the student grows in ability.] 




\section{BIRD-STUDY}

Bird study in the field must be done alone or by pupils in very small groups, for it is difficult for a large class to get close to birds. Go and sit down quietly in some locality where birds are abundant and watch them as they come near. Fix your attention on one bird and study it until, with the aid of the attached key, you can determine what it is. (Chapman's Handbook of the Birds of Eastern United States and Canada for adult pupils and Reed's Bird Books for grade pupils will be found invaluable as the study progresses.) Do not be content merely to know the bird's name; watch it to know its habits.

Parts of bird.-Copy on the opposite page from Chapman's Handbook of the Birds the outline drawing of a bird, showing the location of the areas where distinguishing colors and other marked characteristics are most likely to be found. Study it to familiarize yourself with these.

Field study. - Take this notebook with you on your field trips and while observing an unknown bird either check the term which describes the character or fill in the word indicating the color or other feature in so far as you can observe such. The following are the most important color terms: olive, rufous, buff, fuscous, scarlet, cardinal. (See Chapman's Handbook, p. $3^{8}$, for plate showing these colors and others that are already familiar.)

Date.............................. Length of bird.

Bill: Color......Length......... Slender or short; hooked; bristles at base.

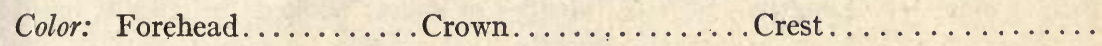

Nape........Back....... Rump......... Throat.........

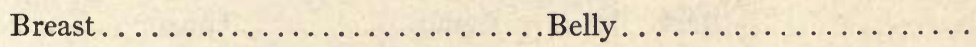

Eye.

Line over eye.

Lores

Tail: Long or short; square at end, V-shaped, round, pointed. General color........................... bars or bands; marked by

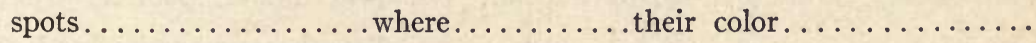

Wings: Long, narrow; wing bars: none, one, or two. Color.

Color on bend of wing............. Outer primaries

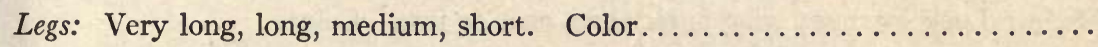
Feet. Webbed. Color................................. long, clawed. Name of bird.........................mily.

I Such as woods, borders of woods, in bushes, open fields, swamps, along stream or pond margins, roadsides, garden, orchard. 
For practice fill in the foregoing details while studying a mounted specimen of a flicker in the school museum. Use the sheets that follow for recording field observations.

Date............... Locality ............. Length of bird

Bill: Color....... Length....... Slender or short; hooked; bristles at base. Color: Forehead............ Crown............. Crest............ Nape...........Back...... Rump............Throat....... Breast..................... Belly

Eye...........Line over eye..............Lores . .

Tail: Long or short; square at end, V-shaped, round, pointed. General color..................... Cross bars or bands; marked by spots............. where..........their color

Wings: Long, narrow; wing bars: none, one, or two. Color

Color on bend of wing. Outer primaries

Legs: Very long, long, medium, short. Color . .

Feet: Webbed. Color. Toes: long, clawed. Name of bird. Family.

Date. Locality. Length of bird Bill: Color...... Length......... Slender or short; hooked; bristles at base. Color: Forehead Crown Crest.

Nape Back. Rump Throat. .

Breast Belly

Eye Line over eye Lores

Tail: Long or short; square at end, V-shaped, round, pointed. General color Cross bars or bands; marked by spots where their color

Wings: Long, narrow; wing bars: none, one, or two. Color

Color on bend of wing. Outer primaries

Legs: Very long, long, medium, short. Color.

Feet: Webbed. Color. Toes: long, clawed. Name of bird Family. 
Date. . Locality . Length of bird

Bill: Color.......Length......... Slender or short; hooked; bristles at base.

Color: Forehead Crown Crest .

Nape . Back. .Rump . . Throat

Breast. Belly .

Eye Line over eye

Lores

Tail: Long or short; square at end, V-shaped, round, pointed. General color Cross bars or bands; marked by spots where their color . .

Wings: Long, narrow; wing bars: none, one, or two. Color

Color on bend of wing. Outer primaries

Legs: Very long, long, medium, short. Color.

Fcet: Webbed. Color. Toes: long, clawed. Name of bird

Family.

Date Locality . .. Length of bird Bill: Color.......Length....... Slender or short; hooked; bristles at base. Color: Forehead Crown Crest.

Nape. Back Rump Throat. . .

Breast Belly

Eye Line over eye. Lores.

Tail: Long or short; square at end, V-shaped, round, pointed. General color Cross bars or bands; marked by spots. . where their color

Wings: Long, narrow; wing bars: none, one, or two. Color

Color on bend of wing Outer primaries

Legs: Very long, long, medium, short. Color.

Feet: Webbed. Color Toes: long, clawed. Name of bird Family 
Date. Locality

Length of bird

Bill: Color......Length......... Slender or short; hooked; bristles at base. Color: Forehead............ Crown............. Crest.

Nape..........Back........Rump......... Throat .

Breast. ................... Belly

Eye.

Line over eye.

Lores

Tail: Long or short; square at end, V-shaped, round, pointed. General color . Cross bars or bands; marked by spots where their color

Wings: Long, narrow; wing bars: none, one, or two. Color.

Color on bend of wing. Outer primaries

Legs: Very long, long, medium, short. Color. .

Feet: Webbed. Color. Toes: long, clawed. Name of bird Family.

Date Locality Length of bird Bill: Color.......Length......... Slender or short; hooked; bristles at base.

Color: Forehead. . Crown Crest.

Nape . . Back Rump Throat

Breast Belly. . .

Eye. Line over eye Lores

Tail: Long or short; square at end, $V$-shaped, round, pointed. General color Cross bars or bands; marked by spots where their color

Wings: Long, narrow; wing bars: none, one, or two. Color. Color on bend of wing. Outer primaries

Legs: Very long, long, medium, short. Color.

Feet: Webbed. Color. Toes: long, clawed. Name of bird. . Family 
Date

Locality

Length of bird

Bill: Color.......Length....... Slender or short; hooked; bristles at base. Color: Forehead. . Crown .. Crest . .

Nape. Back. . Rump Throat. .

Breast. Belly

Eye. Line over eye Lores

Tail: Long or short; square at end, V-shaped, round, pointed. General color Cross bars or bands; marked by spots . where their color .

Wings: Long, narrow; wing bars: none, one, or two. Color .

Color on bend of wing.

Outer primaries

Legs: Very long, long, medium, short. Color .

Feet: Webbed. Color Toes: long, clawed. Name of bird Family.

Date. Locality Length of bird

Bill: Color.....Length......... Slender or short; hooked; bristles at base. Color: Forehead. . Crown. Crest.

Nape. Back. Rump Throat. . .

Breast. . Belly.

Eye .Line over eye.

Lores

Tail: Long or short; square at end, V-shaped, round, pointed. General color . Cross bars or bands; marked by spots where their color

Wings: Long, narrow; wing bars: none, one, or two. Color.

Color on bend of wing. Outer primaries

Legs: Very long, long, medium, short. Color

Feet: Webbed. Color. Toes: long, clawed. Name of bird Family.

Bird record.-During this fall (or spring) keep a record of the birds you see, using the following tabulation. Number $\circ$ is filled in as a sample. 
A FIELD GUIDE IN NATURE-STUDY

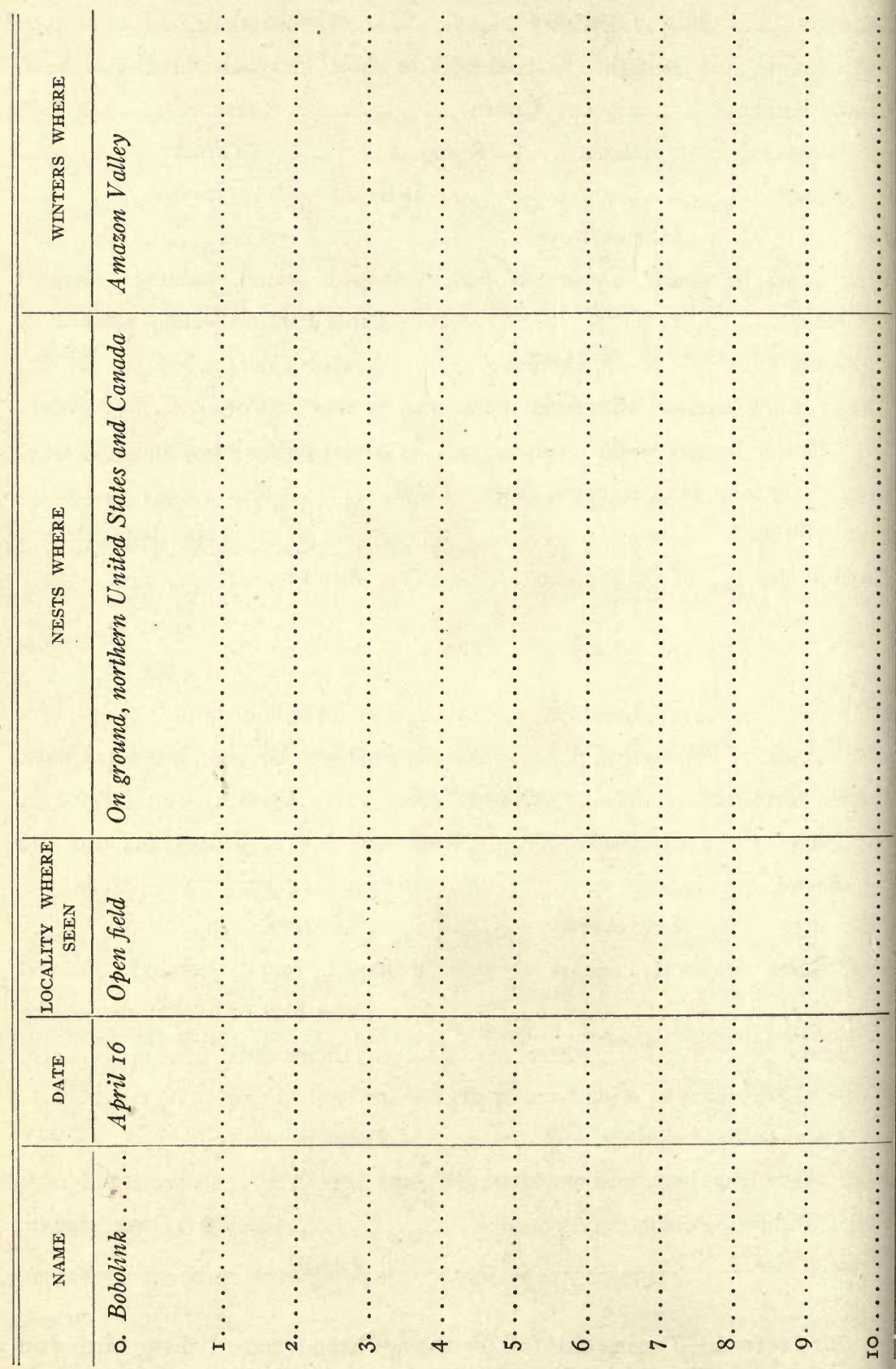




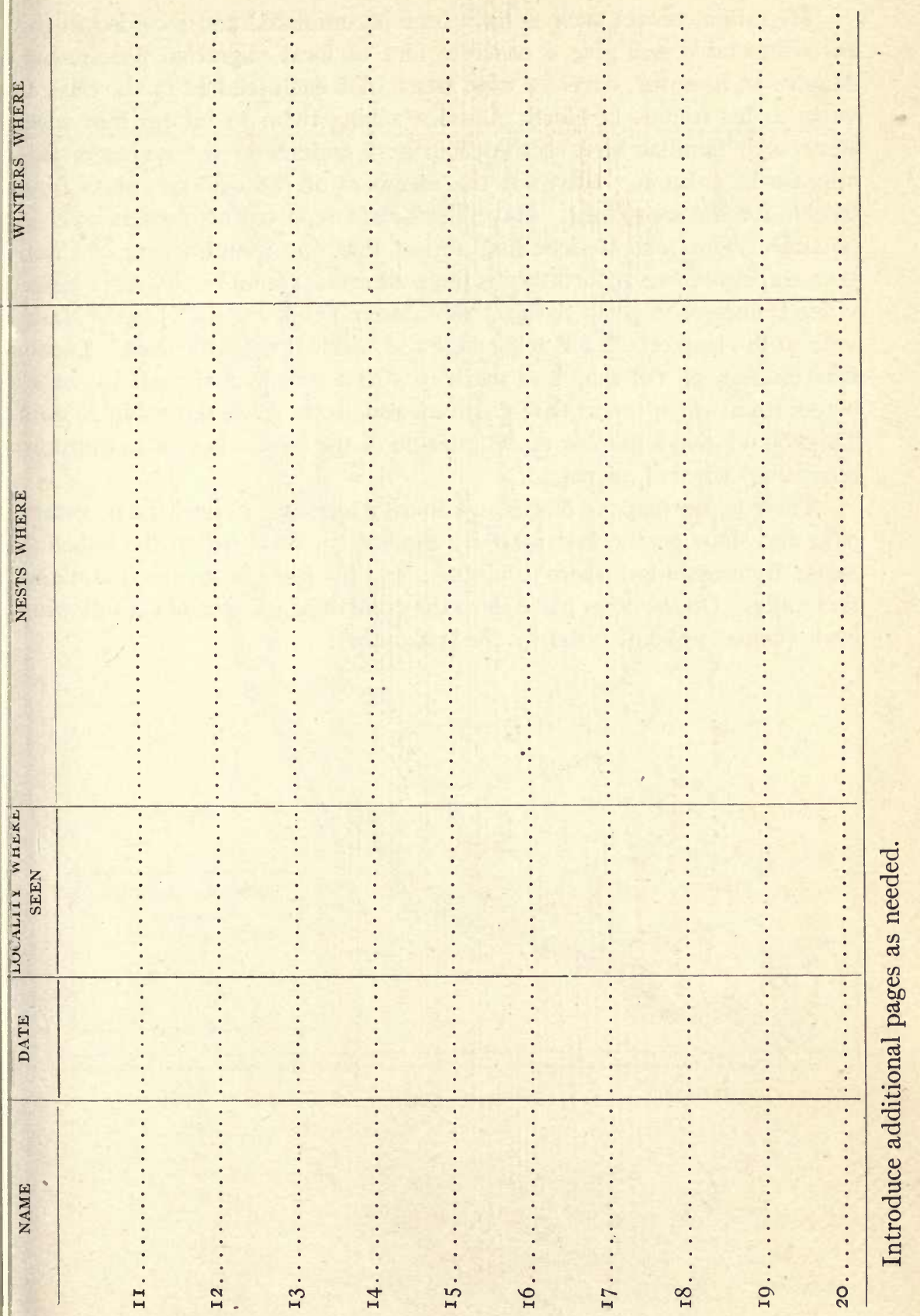


Migration.-Data such as have been accumulated and recorded in the preceding table will give a concrete idea of local migration phenomena. Migration, however, covers a wide area. Ask each student in the class to write to his friends in North America asking them to inform him when some such familiar bird as the robin first appears in the spring or last appears in autumn. Have all the members of the class get data from friends for the same bird. Have these data reported at class as soon as possible. Thus one student may report that one friend, living in Chattanooga, Tennessee, reports robins there all winter; another, living in Nashville, Tennessee, reports the first robin seen February i6. Locate Nashville on the map on the following page and beside it write the date. Locate Chattanooga on the map and mark it with a red dot; also all the other places from which reports are received and dates when the robin is seen. This should give a graphic representation of the advancing (or in autumn, retreating) wave of migration.

There follow maps of North and South America. Collect the necessary data and show on the first map, by shading, in what region the bobolink nests; by cross-lines, where it winters; and by a line of arrows, its migration route. On the other maps show the same thing for each of the following birds (names to be dictated by the instructor): 


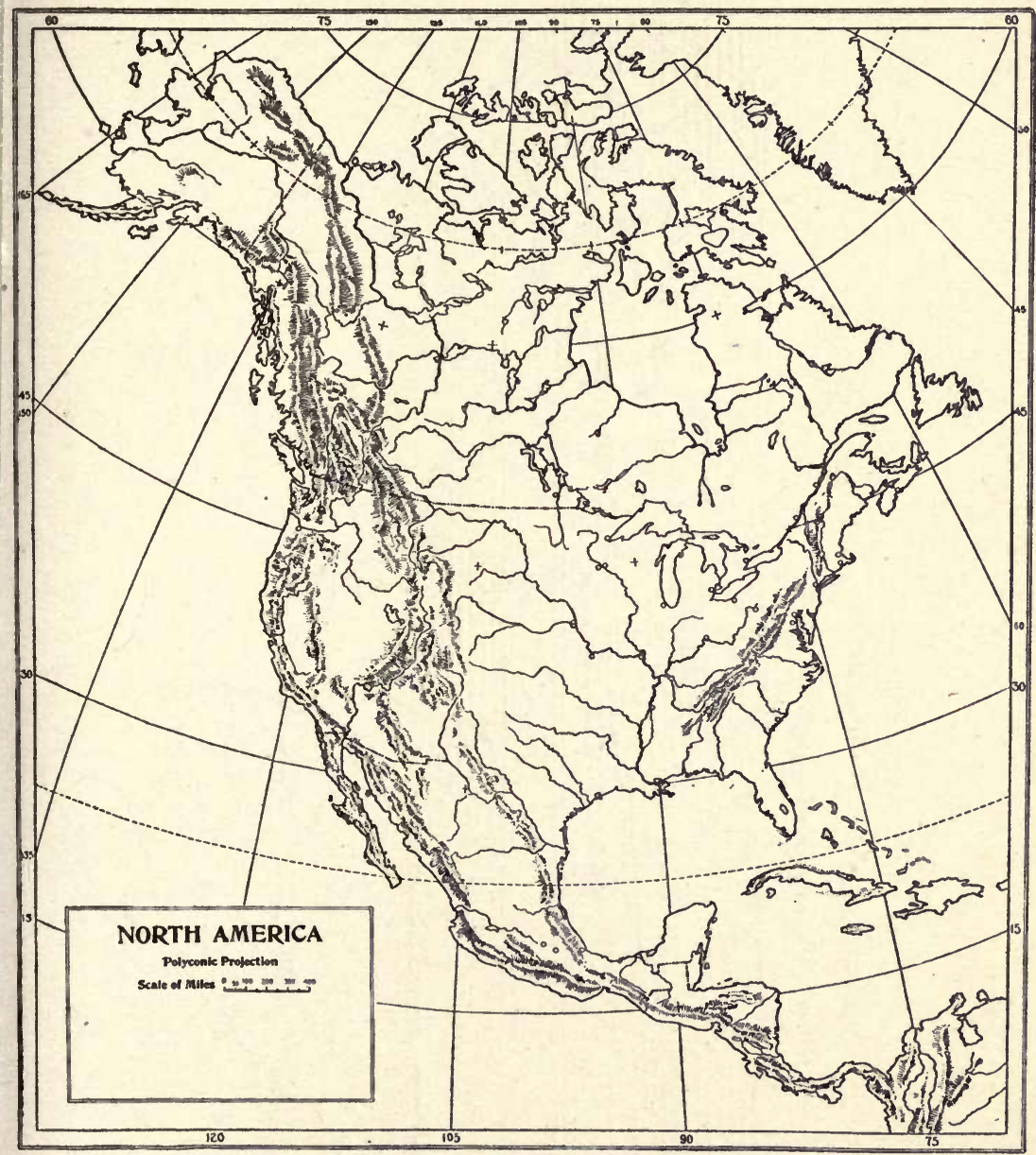

FIg. 6 


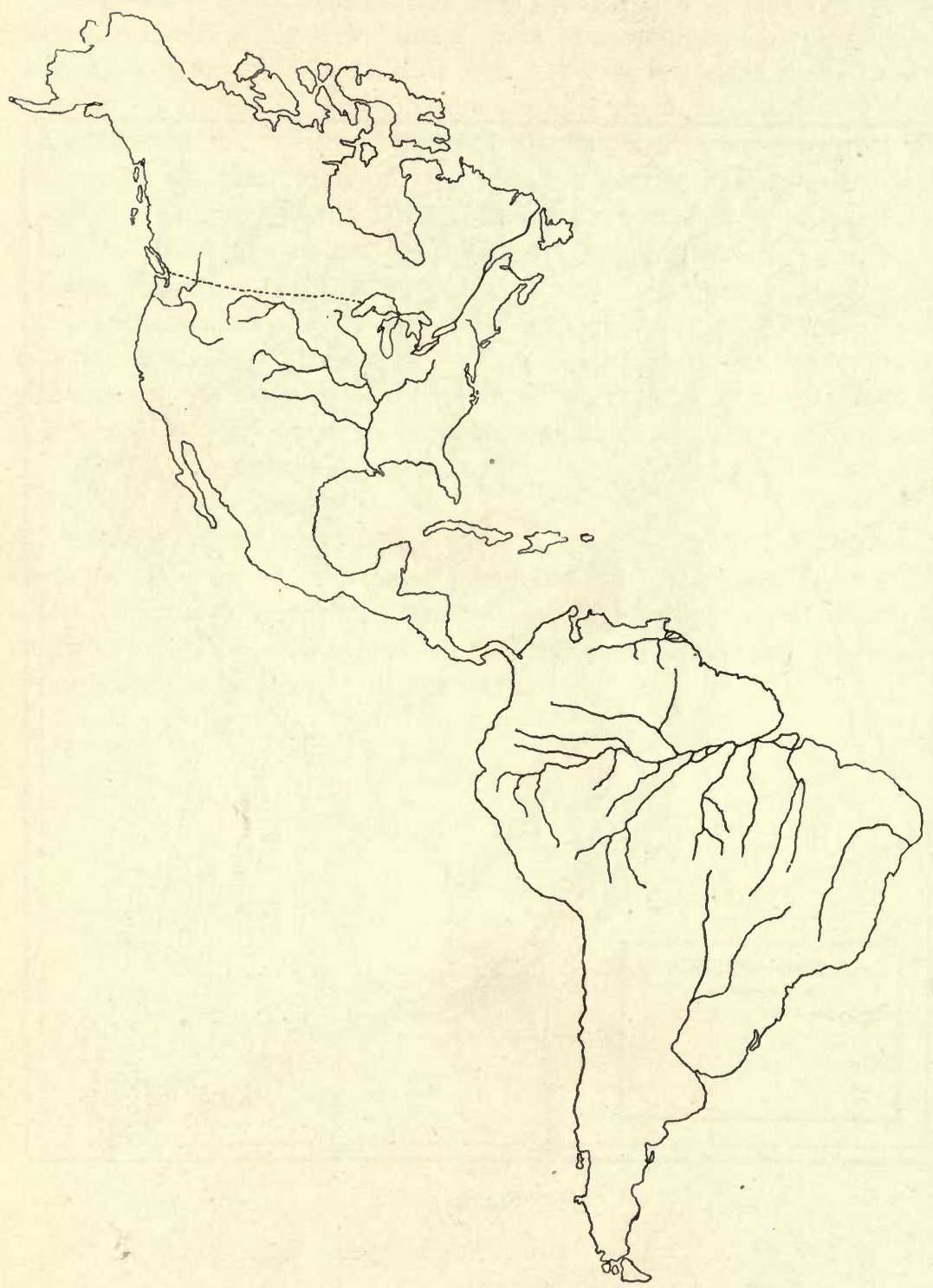

FIG. 7 


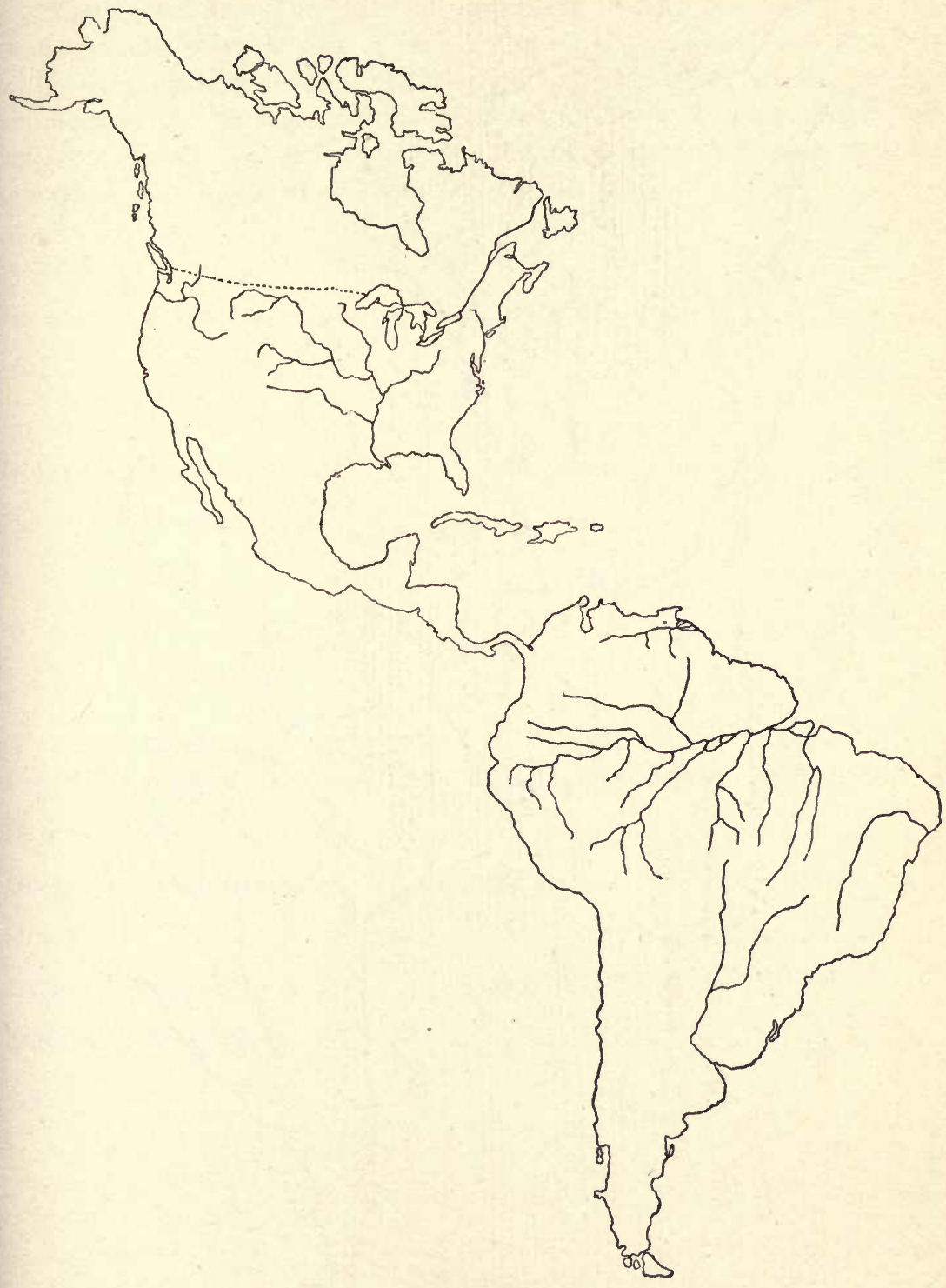

FIG. 8 


\section{A FIELD GUIDE IN NATURE-STUDY}

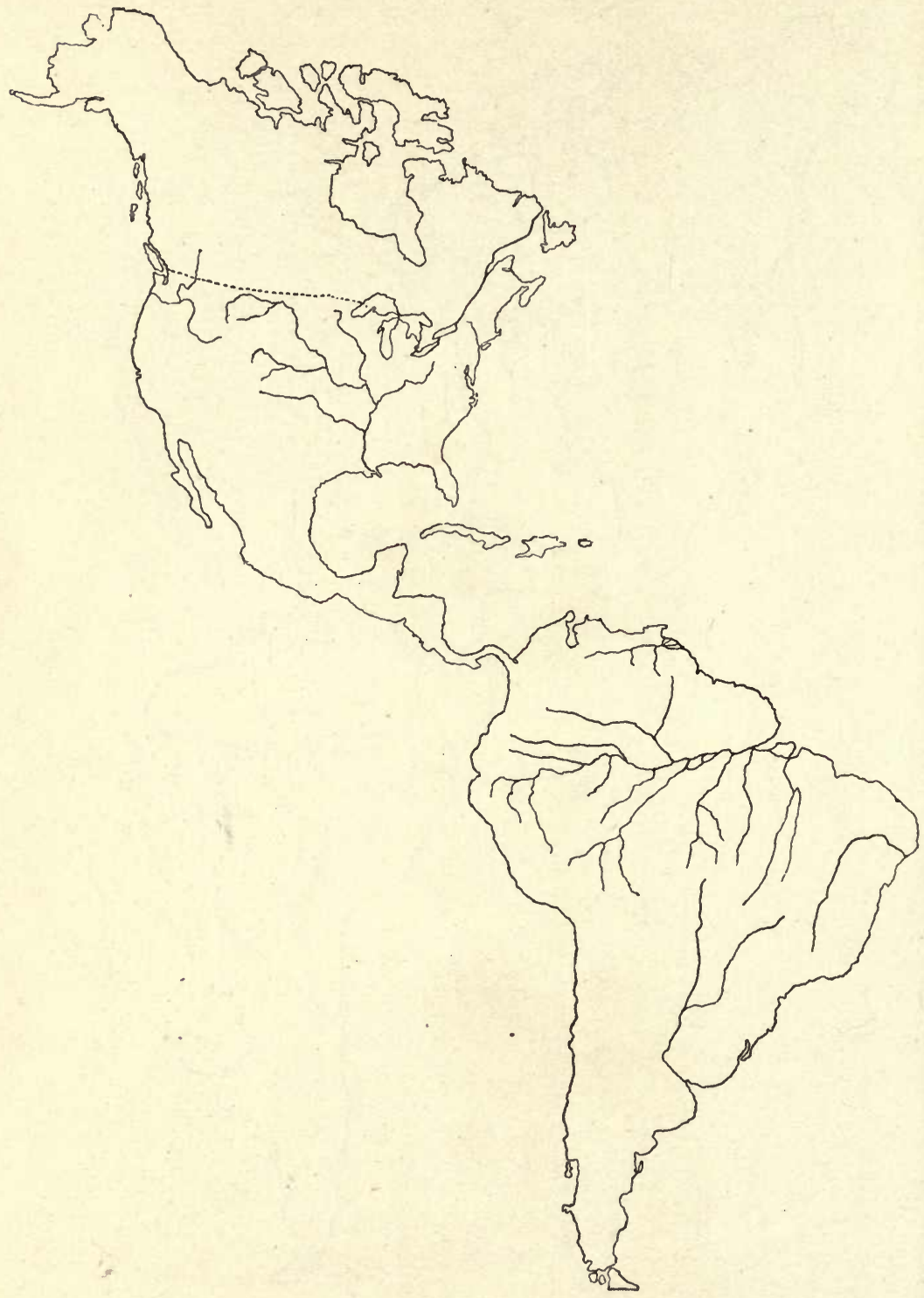

FIg. 9 
Nesting habits.-The class will undertake to keep close watch of the nesting habits of some pair of birds. Locate a convenient nest which is within easy walking distance of the school and sufficiently low so that the activities of the birds are readily observed. A pair of opera glasses will help in this work. Assign students to particular days and hours so that the procedure may be under constant observation.

Name of bird

Location of nest site

Date of beginning of nest

Date of completion

Description of nest.

Date first egg is laid.... Second.... Third.... Fourth.... Fifth .

Date female begins incubation.

Does male also sit on eggs?.

When?

How long?

Date first young hatch.

Second

Third

Additional observations.

Record on the blanks on the following pages one day's activities while young are being fed. Begin observation early enough to catch the first feeding and continue until it is discontinued for the day. Pupils may work at the job of observing and keeping record in hour shifts. 
NAME OF BIRD.

DATE.

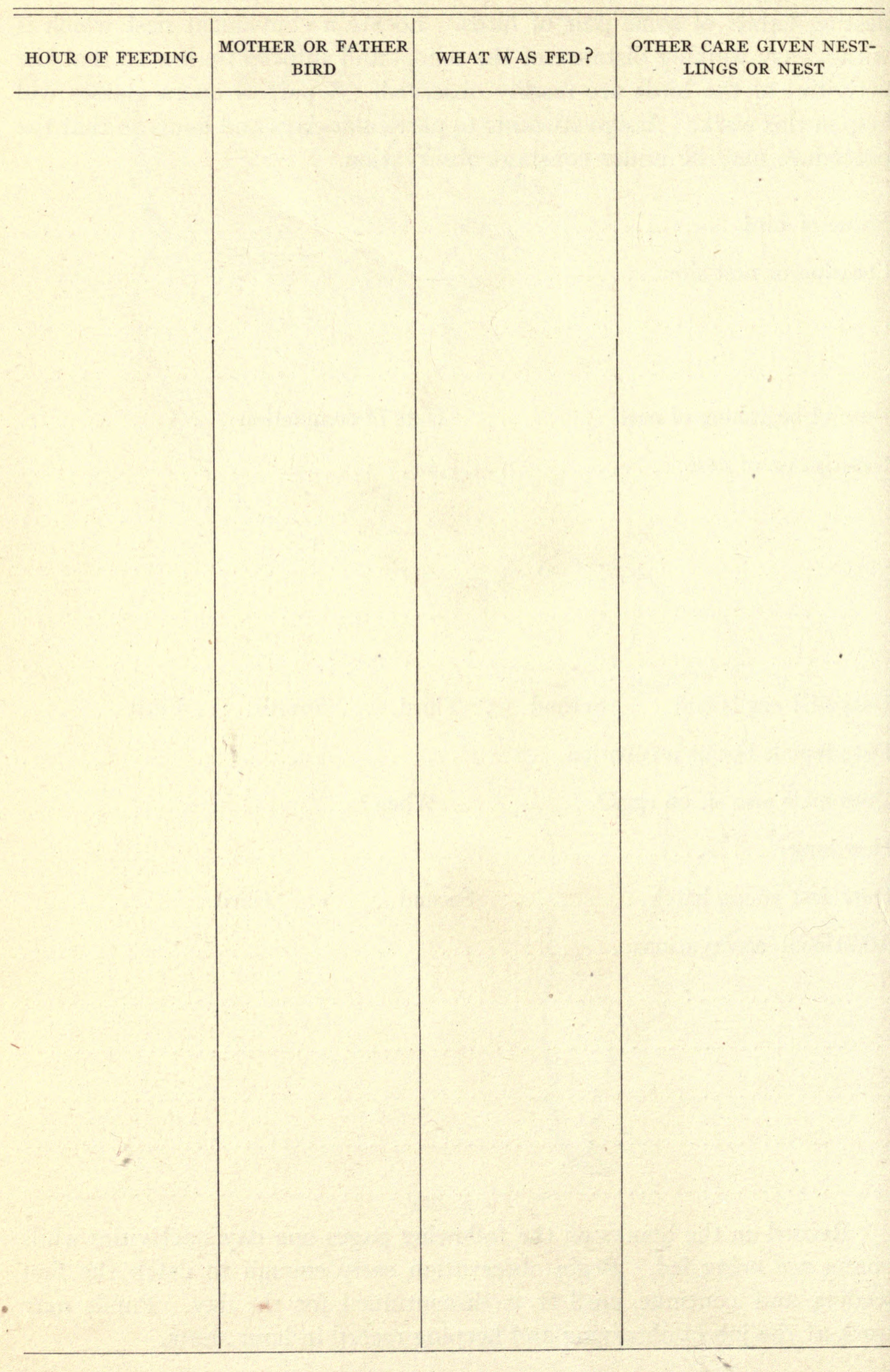




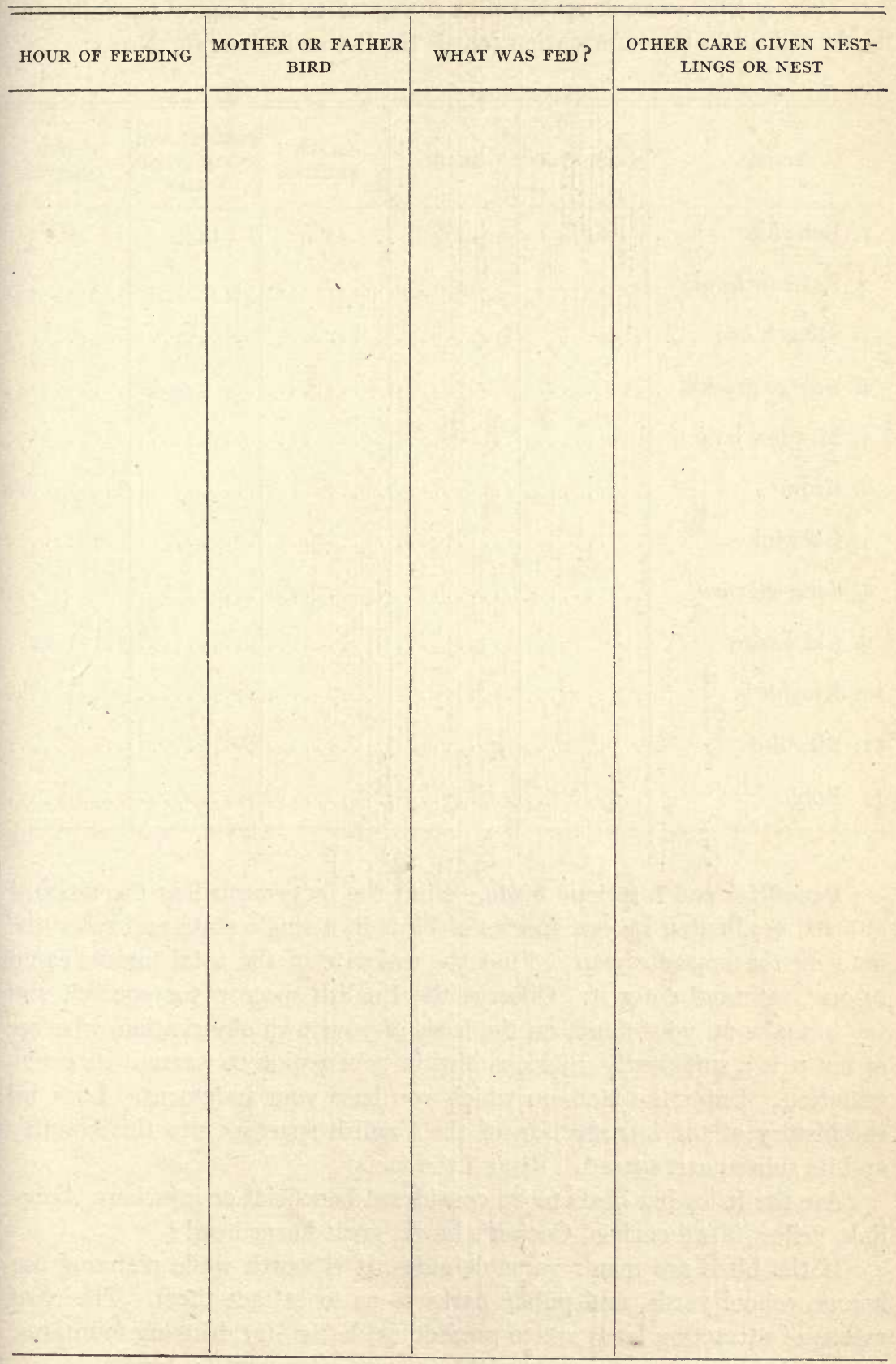


Food of birds. - Look up the data in regard to the food of the following birds and fill in the information for all the list as is done for No. I:

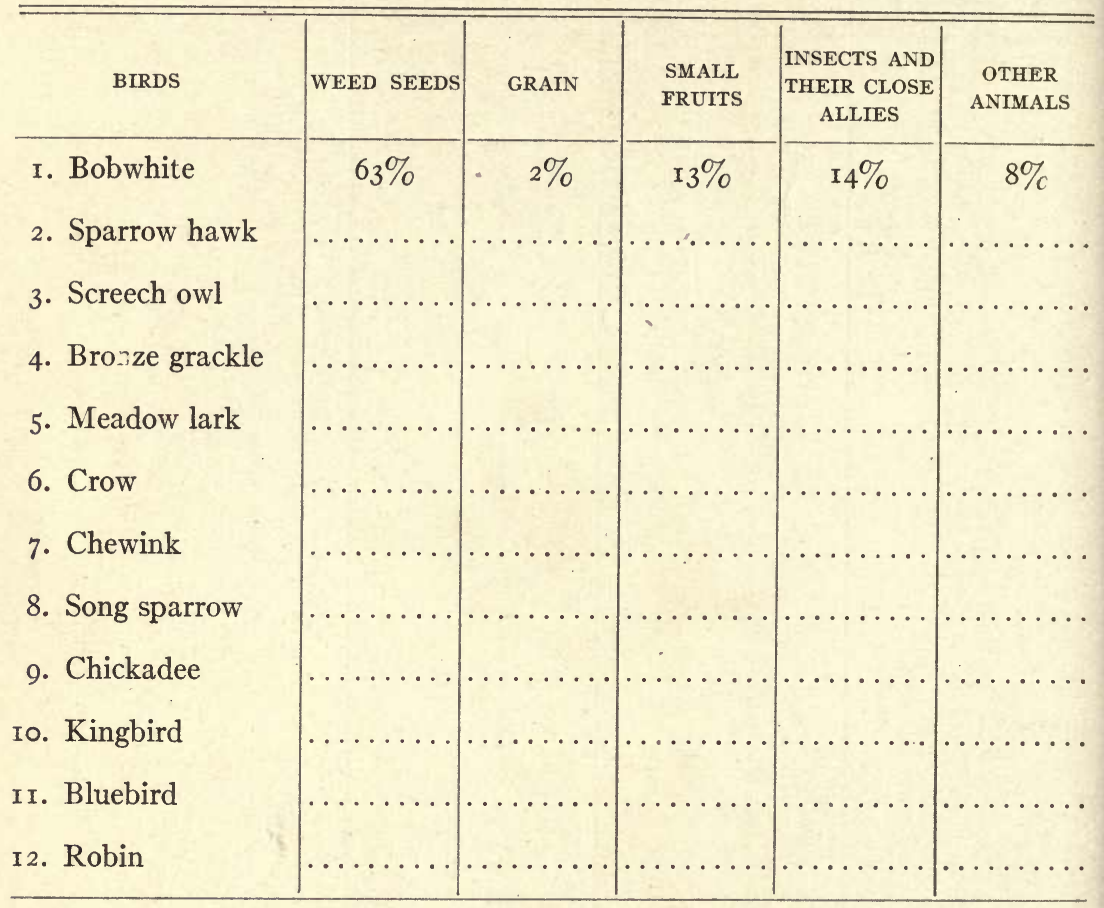

Beneficial and injurious birds.-Find the facts regarding the amount of weed seed eaten by one species of birds in a single state and enter the data on the opposite page. Find the estimate of the total insects eaten in one state and enter it. Observe the English sparrow for yourself and try to make up your mind, on the basis of your own observation, whether or not it is a sufficiently injurious bird in your region to warrant its extermination. Enter the facts on which you base your judgment. Look up the history of the introduction of the English sparrow into this country and its subsequent spread. Record the facts.

Are the following birds to be considered beneficial or injurious: bobolink, yellow-billed cuckoo, Cooper's hawk, great horned owl?

If the birds are man's valuable allies, it is worth while planning our homes, school yards, and public parks so as to attract them. The chief means of attracting birds are to provide $(a)$ baths, $(b)$ drinking fountains, $(c)$ nest boxes and nesting materials, $(d)$ nest sites, and $(e)$ food. 


Bath and drinking fountain.-Copy or design a good combination bath and drinking fountain. It would be a worth-while project to undertake to make one as a class enterprise. Before undertaking it read up on the essential things in such a device so as to make it really attractive to the birds.

Nest boxes. - What is the essential thing in a wren box? The purple martin nest should be located on a pole above low shrubbery, near a pond. It should have nest sites for many pairs, and these should be away from drafts. It must have several entrances so that if sparrows take possession the martins can get in to drive them out. Draw on the opposite page the plan for such a nest.

Food and shelter.-Birds may be fed out of the hand with prepared food; or trees, shrubs, and herbs may be grown to furnish them food. If grown in a tangle the thicket will afford excellent nest sites. What are some of the good foods to use in attracting birds about the house? List some of the best plants, classifying them under trees, shrubs, herbs, to put into the tangle or upon the lawn to afford edible fruits to birds. Draw a map of the block in which you live, locating on this the position of houses, trees, shrubbery, gardens, etc., and indicate by a red-ink dot the location of each bird nest; a little number beside the dot may refer to the margin and show the name of the bird owner.

Comparative study of the parts of birds.-Draw from specimens in the school museum the heads of the following birds to show bill structure:

The head of the cardinal. What is the food of the bird and why the heavy beak?

The bill is really a

Other birds with the same type of bill are 
The head of a hawk. The bill is used for Other birds with this type of bill are

The head of the ficker. The bill is really a... and its tip is .like a . . Look up a sketch of the tongue of the bird (see Chapman). It is used.

The head of the woodcock. The food is obtained by

Why are the eyes set so far back in the head?

The head of the American bittern. The bird feeds on and the bill is a . Why is the neck so long?.

What other birds have similar bills?

The nighthawk. The bird captures its food

So the. must be very.

What other birds have like habits? 


Birds' feet.-Draw the foot of the duck, built for............... Compare the foot of the grebe. Why are the legs placed so far back?

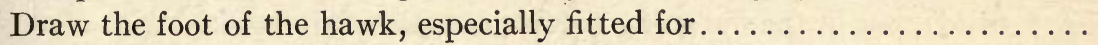
Draw the foot of the gallinule, coot, or rail. What other birds have such feet as the rail? What kinds of legs have they as a rule? Draw the foot of a chicken or turkey. Examine the foot of a turkey or of a chicken when it has been cut off. Is it closed or open? When you pull on the tendons, the white cords at the cut, what happens? In the living animal muscles work these tendons. Would it require effort on the part of the bird to grasp its perch or to let go? How would this be an advantage?

The wing.-Draw in outline one of the main wing feathers, a wing primary, from the wing of chicken or turkey. It consists of (I) the quill and (2) the vane, the latter made up of $(a)$ the shaft and $(b)$ the web. Is the web equally wide on both sides of the shaft? If you were to cut across the wing primaries as they lie in the wing, the cut of the shafts might appear something like this . . . . . (Attach lines to these dots to show how the web of each feather would lie.) A bird flies by beating the air with its wings. But when the wing has arrived at the end of the downstroke it must carry back again to begin the next. Why does not the upstroke undo all the lifting effect of the downstroke? Watch birds to see if the downstroke is more rapid than the up.

\section{FIELD KEY TO CHICAGO BIRDS}

To use a key of this sort when you are trying to identify a bird that you see in the field, read through the description of the several groups lettered A-I, A-2, etc. Select the one that fits the bird under observation, then read under this heading the characters of the several alternative groups lettered E, EE, etc. Such alternative groups always stand under each other in line at the same distance from the left-hand margin of the page. Continued selection narrows down the choice until the final one leads to the name of the bird.

The several major groups from which selection is to be made in the order of their occurrence are as follows:

A-I. Ducks or ducklike birds with characteristic throbbing flight.

A-2. Birds of soaring flight usually seen on the wing: gulls, terns, hawks, buzzards, swallows, swifts, etc.

A-3. Birds with feathered rosettes around the eyes: owls.

A-4. Birds conspicuous for their long necks and long legs: herons, rails, sandpipers.

A-5. The woodpeckers. 
A-6. The flycatchers that watch for insects from a perch and return after securing the prey.

A-7. Birds, not in the foregoing groups, conspicuously marked with blue.

A-8. Birds conspicuously marked with red.

A-9. Birds conspicuously marked with yellow.

A-ro. Birds that appear chiefly brown.

A-II. Birds that are black or black and white.

A-I2. Birds that will not go into any of the foregoing groups.

A-I. Ducks or ducklike birds, with characteristic throbbing flight

E-Diving rather than flying when startled and remaining under the water for some considerable time; almost tailless.

$\mathrm{I}-$ More than $2 \mathrm{ft}$. in length (as large as a goose)

Loon

II-Less than $2 \mathrm{ft}$. in length

$\mathrm{O}-$ White wing patch showing when wing is flapped in flight; under parts pure white; head usually black or yellow, or black and white

OO-No wing patch; under parts ashy $\mathrm{X}$-Bill round, short

XX-Bill flat, upcurved

EE-Flying rather than diving when startled, or, if the latter, remaining under for a few moments only; with tail. Ducks and geese.

I-Crested

$\mathrm{O}-$ Crest sticking up like a pompadour; a white spot on it

$\mathrm{X}$-Neck black

XX-Neck white

Hooded Merganser

Bufflehead, male

OO-Crest hanging down neck

$\mathrm{X}$-Breast spotted

$\mathrm{Y}$-Chin white

YY-Chin dark

Horned Grebe

Pied-billed Grebe

Ruddy Duck

-Breast not conspicuously spotted

Y-Head black, breast brown, streaked with black

YY - Head brown, breast whitish $a$-Crest double; double white wing patch Red-breasted Merganser, female $a a$-Crest single; single white wing

II-No crest patch

American Merganser, female

$\mathrm{O}$-Tail with long slender feathers

$\mathrm{X}$-Head dark, no white spot

Pintail 
$\mathrm{XX}-$ Head light, or, if dark, with a white spot on each side

Old Squaw

OO-Tail without long slender feathers

$\mathrm{X}$-Animal all over uniform black or

dusky, except possibly some white spots

$\mathrm{Y}$-No white spots anywhere

$a$-Unmottled; underwings, seen in flight, dark

American Scoter

$a a$-Mottled; underwings, seen in flight, light

Black Duck

YY-With white spots

$a$-White wing bar, male with white eyespot

White-winged Scoter

$a a-N o$ white wing bar but two white spots on each side of head

o-Forehead low

Surf Scoter

oo-Forehead high

$\mathrm{XX}$-Animal not uniform black or dusky all

Harlequin Duck, female over

Y-Forward parts dark, contrasting strongly with adjacent light parts

$a$-Head and sometimes neck dark, contrasting strongly with light neck or breast

o-Back light, bill broad and spoonlike

oo-Back dark

$x$-Bird nearly $3 \mathrm{ft}$. long.

Flying in V-shaped flocks

$x x$-About $2 \mathrm{ft}$. or less in

length

$y$-White spots on head

z-A white spot be-

hind eye

$z z-A$ white spot be-

low the eye

Shoveller, male

Canada Goose

$y y$-No white spots on

head

z-Head black, feet red; 26 in. long

American Merganser, male

$z z$-Head brown, feet yellow or orange; I 8 in. long

Golden-eye, female 
$a a$-Head, neck, and breast dark, contrasting strongly with adjacent light parts

0 -Back light

$x-\mathrm{A}$ narrow white ring around neck; tail feathers curled up

$x x$-No narrow white ring on neck; tail feathers straight

$y$-Forehead low, bill long

$y y$-Forehead high, bill short

z-Head black; white spot on wing

zz-Head red; no white spot on wing

oo-Back dark, chin light, belly light

YY-Forward parts not in strong contrast to adjacent light parts but shading into lighter belly; animal variegated or spotted (in females listed below spots not seen at a distance)

$a$-Animal slaty blue with several crescents and spots on head and body

$a a$-Animal not so marked

o-A dark comma running back from eye

$x$-Top of head white

Baldpate, male

$x x$-Top of head chestnut

oo-No dark comma running back from eye

$x$-Wing with large blue patch on it

$y$-Bill broad and spoonlike

$y y$-Bill not broad and spoonlike

z-Head gray, a white crescent in front of eve

Harlequin Duck, male

Canvasback

Scaup, male

Redhead

Ring-necked Duck

Green-winged Teal, male

Shoveller

Blue-winged Teal, male 
$z z-$ Head and under parts a bright cinnamon

Cinnamon Teal, male

$z z z-$ Head and wings dusky \$-Throat white

Blue-winged Teal, female ¥-Throat dark

Cinnamon Teal, female $x x$-Wing without large blue patch on it

$y$-Wing patch white bordered with black Gadwall

$y y$-Wing patch violet bordered front and back with white

Mallard, female $y y y$-Wing patch green z-Large white patch in front of it $z z-$ No white patch on wing

Green-winged Teal, female

A-2. Birds of soaring flight usually seen on the wing; wings long and sharp-pointed

E-Bill hooked; birds (except for a few) considerably larger than a robin; this group includes the gulls, terns, hawks, and buzzards

I-Feet webbed and extended backward in flight, usually seen over bodies of water, flying rather low and in straight lines

O-Pearl gray above, white or light below

$\mathrm{X}$-As large as or larger than a crow

$\mathrm{Y}$-Top of head black, bill coral red, feet black, tail forked, male crested

$\mathrm{YY}$-Head white, tail square

$a$-Bill unmarked, length 24 in.

$a a$-Bill with dark, encircling band, lenth $18 \frac{1}{2}$ in.

Note.-Immature birds, often seen flying with the old ones, are much darker; tail of mature herring gull has the buffy border. The ring-billed gull has a wide black border.

Caspian Tern

Herring Gull

Ring-billed Gull 
$\mathrm{XX}-\mathrm{Nearly}$ one and one-half times as large as a robin

$\mathrm{Y}$-All of head and throat dark

$a$-Bill red, under parts suffused with pink

$a a$-Bill black, under parts white

YY-Top of head black (in winter crown

Franklin's Gul

Bonaparte's Gull white)

$a-$ Feet and bill orange; under parts white

$a a-$ Feet and bill red; breast and belly pale gray

$\mathrm{XXX}$ - About as long as a robin, slender; belly yellow, feet orange

OO-Bird dark all over

$\mathrm{X}$-Body black, wings dark, small

$\mathrm{XX}-$ Body and wings dark, large

Young of Herring and Ring-billed Gulls (see p. 89)

II-Feet not webbed, held up close to the body in

flight; usually seen over the land (except fish

hawk), flying at a considerable height and in wide sweeping curves; marsh hawk flies low and some of the hawks fly in straight lines, but all are usually easily recognized as hawks, their flight is so swift

$\mathrm{O}-\mathrm{Head}$ without feathers

$\mathrm{X}$-Red head

$\mathrm{XX}$-Black head

OO-Head feathered

$\mathrm{X}$-Nearly $3 \mathrm{ft}$. long

$\mathrm{Y}$-Head white; leg not feathered clear down to toes

YY-Head not white; leg feathered to toes

$\mathrm{XX}-2 \mathrm{ft}$. or less in length

Turkey Buzzard

Black Vulture

Y-Tail without cross-bars or bands

(tip may be white) (the black band on red-tailed hawk does not show clearly from below)

$a$-Under parts streaked

Red-shouldered Hawk, immature $a a$-Under parts unstreaked o-A band across the belly

Rough-legged Hawk, immature 
oo-No band across the belly

$x$-Under parts white or

whitish

$y$-Rump white

Marsh Hawk

$y y$-Rump not white

z-Head and back

slate-colored, under parts gray

Goshawk, male

zz-Head white, back brown, under parts

white

Fish Hawk

$x x$-Under parts dark

$y$-No white spots under-

side of wing

Rough-legged Hawk, dark variety

$y y-\mathrm{A}$ white spot under each wing

Night Hawk (not a true hawk but sometimes mistaken for one when flying)

YY - Tail with cross-bars or bands

$a-\mathrm{A}$ single black band near end

o-Back barred; Io-I I in.

oo-Back unbarred; $2 \mathrm{I}$ in.

Sparrow Hawk

Red-tailed Hawk

$a a$-Several cross-bars or bands

o-Breast, belly, sides, or all of

them cross-barred

$x$-White patch at base of

tail in sharp contrast to

adjacent dark parts

$y$-Basal half of tail white; perches high

$y y$-Only rump white; perches low

Rough-legged Hawk

Marsh Hawk

$x x$-No white patch at base of tail

$y$-Breast with big cinnamon spot

Swainson's Hawk, male

$y y-$ Breast without cinnamon spot

z-Wing primaries

without bars

‡-Tail with two

bars 
$\$$ \$-Tail with more than two bars; belly with black band

Red-tailed Hawk, immature $z z-W i n g$ primaries with bars; tail more than two bars \$-Tail square in flight. Bird I $I-I_{3}$ inches

Sharp-shinned Hawk

¥-Tail rounded in flight; larger

$\S$-Shoulder and breast red; top of head light, streaked

Red-shouldered Hawk

\$-Shoulder and breast not red; top of head dark, unstreaked

I. Length 16

Cooper's Hawk

2. Length 24

Goshawk

oo-Breast, belly, sides without cross-bars $x$-Breast, belly, sides all streaked

$y$-Wing primaries barred

z-As large or larger than a crow

\$-A brown spot on breast

Swainson's Hawk, female

\$-No brown spot on breast §-Shoulder yellow buff

Red-shouldered Hawk, immature §-Shoulder not yellow buff

Goshawk, immature zz-Much smaller than a crow ¥-Tail rounded in flight Cooper's Hawk $\ddagger$-Tail square in flight §-Buff collar about neck Pigeon Hawk $\S \S$-No buff collar 
$y y$-Wing primaries unbarred

z-White at base of tail

\$-Basal half of tail white

Broad-winged Hawk

$\ddagger$-Only rump white

Marsh Hawk

$z z-$ No white at base of

tail

\$-Tail with three to

five black bars

Broad-winged Hawk, immature

\$-Tail with more

black bars

Swainson's Hawk, immature $x x$-At least the belly unstreaked, white

$y$-White rump

Marsh Hawk

$y y$-Rump not white

$z$-Head light

Fish Hawk

$z z$-Head dark

Broad-winged Hawk, immature

EE-Bill not hooked: swallows, swifts, and nighthawks

I-A white spot on underside of dark wing

Nighthawk

II-No white spot on underwing

O-Entire bird one color, no conspicuous marks;

bird black or very dark

$\mathrm{X}$-Tail somewhat forked

Purple Martin, male

$\mathrm{XX}$-Tail not forked but tipped with bristles

OO-Bird not all over one color

$\mathrm{X}$-Tail deeply forked

$\mathrm{XX}$-Tail not deeply forked

Y-Throat chestnut

Chimney Swift

YY - Throat gray or white

$a$-Under parts all white

$a a$-Under parts not all white

o-A black band across the breast

Barn Swallow

Cliff Swallow

Tree Swallow

oo-No black band across the

Bank Swallow breast

$x$-Upper parts with metallic reflections

Purple Martin, female

$x x$-Upper parts without metallic reflections Rough-winged Swallow 
A-3. Bill hooked; feet not webbed, held up to the body in flight; low-flying; feathers around eyes forming rosettes

$\mathrm{E}-\mathrm{About}$ the size of a crow or somewhat smaller

I-With distinct ear tufts (see also short-eared owl, below)

$\mathrm{O}-\mathrm{A}$ white patch on throat; rare

$\mathrm{OO}-\mathrm{No}$ white patch on throat; rare

II-No distinct ear tufts

$\mathrm{O}-$ Feathers of upper parts barred; a forest owl; usual cry a deep-voiced "Who-whoowhoo, who-whoo, to-whoo-ah"

$\mathrm{OO}-$ Feathers of upper parts not barred

$\mathrm{X}$-Upper parts speckled in black and white; monkey-faced

$\mathrm{XX}$-Upper parts not speckled with white; ear tufts short, scarcely seen; found in swamps, on the ground; rare

$\mathrm{EE}$-Not larger than a robin

I-With ear tufts; call a melancholy, tremulous whistle, not a screech

II-No ear tufts; call like the sound of filing a saw

Great Horned Owl

Long-eared Owl

Barred Owl

Barn Owl

Short-eared Owl

Screech Owl

Saw-whet Owl

A-4. Birds conspicuous for their long legs and long necks (long in proportion to the length of the bird); usually found in swamps or along the shores of streams, ponds, and lakes

E-Bill short and stout, forehead bare; black or brown all over

I-Bill white, tipped with black; toes partly webbed

II-Bill red

$\mathrm{O}-$ Crown red; leg just below body red

OO-Crown blue black; leg yellow

EE-Bill long; forehead feathered

I-Space between eye and bill bare; neck folded in flight

$\mathrm{O}-$ Crested

$\mathrm{X}$-Feathers of lower neck hanging in a brush

$\mathrm{Y}$-About $4 \mathrm{ft}$. long

YY-About $2 \mathrm{ft}$. long

$\mathrm{XX}-$ Feathers of lower neck not hanging

Great Blue Heron

Little Blue Heron down

Florida Gallinule

Purple Gallinule

Y-Back green, sides of throat brown Little Green Heron 
YY - Back and sides of neck brown streaked with white Black-crowned Night Heron OO-No crest

$\mathrm{X}-28$ in.; yellow-brown streaked; a black stripe on side of neck

American Bittern

$\mathrm{XX}-\mathrm{I} 3$ in.; back dark; neck chestnut, unstreaked

Least Bittern

II-Space between eye and bill feathered; neck not folded in flight

$\mathrm{O}$-Wings small, rounded (rails)

$\mathrm{X}$-About the size of a robin

$\mathrm{Y}$-Bill longer than head

YY-Bill shorter than head

$\mathrm{XX}$-About the size of a sparrow

$\mathrm{Y}$-Yellow-brown

YY-Black or very dark

$\mathrm{OO}-$ Wings long and pointed (sandpipers, plovers, etc.)

$\mathrm{X}-\mathrm{A}$ white ring around the neck

$\mathrm{Y}$-Two black bands on the breast

YY-One black band on the breast;

forehead light; dark band between eyes

$a$-Very pale, color of light sand;

back not darker than belly

$a a$-Darker, color of wet sand;

back darker than belly

Semi-palmated Plover

$\mathrm{XX}-\mathrm{No}$ white ring around the neck

$\mathrm{Y}$-Bill short, distinctly shorter than head

$a$-All over color of light sand

Piping Plover $a a-$ Not of uniform color

$0-$ As large as or nearly as large as a robin

$x$-General color olive brown

$x x$-General color olive yel-

Pectoral Sandpiper

low; throat, breast, belly

of male black

Virginia Rail

Sora Rail

Yellow Rail

Black Rail

Kildeer Plover

Piping Plover

oo-Scarcely larger than a spar-

Golden Plover row or smaller

$x$-Breast spotted; legs yel- . lowish

Least Sandpiper

$x x$-Breast unspotted; legs

black

Semi-palmated Sandpiper 
YY - Bill considerably over I in.

$a$-Bill very long, over 2 in.; con-

siderably longer than head

$o-$ Bill upturned decidedly

oo-Bill not upturned

$x$-Legs yellow

$x x$-Legs not yellow

$y$-Gray birds, under parts white; shores

$y y$-Brown birds, under parts brown; moist woods

z-Back and head streaked; breast spotted

$z z-$ Back and head not streaked; breast brown, plain

$a a-$ Bill less than 2 in.

0 - Seen in dry fields; 2 in.; legs yellow

oo-Not seen in dry fields

$x$-Legs yellow

$x x$-Legs not yellow

$y$-Throat unstreaked; unspotted

z-Breast rufous; a dark band down side of neck in female

$z z$-Breast white, as also throat

$y y$-Throat streaked or spotted

$z$-Throat rufous, spotted

$z z$-Throat not rufous \$-Throat white, spotted, as also breast

\$-Throat striped

Wilson's Phalarope Sanderling

$\S$-Back red; belly black 
$\S \S-$ Back not red nor belly black; tail barred

Solitary Sandpiper

A-5. The woodpeckers: Birds that habitually go up and down the tree trunks, hanging to the bark with strong clawed toes. (Three small birds, not woodpeckers, have habits somewhat like them. They are the black and white creeping warbler, the brown creeper, and the nuthatch. The latter has a plain blue-gray back, the brown creeper a brown-streaked back and a slender curved bill. The back and wings of the first named are streaked with black and white. It hunts over the twigs and smaller branches rather than on the trunks. All three are small birds, not larger than sparrows.)

$\mathrm{E}-$ With scarlet crest; bird nearly as large as a crow

I-Wing one-half white

II-Wing not white

Ivory-billed Woodpecker

Pileated Woodpecker

EE-With no crest, though top of head or nape maybered

I-Wings with a single broad white band; head of male entirely red

Red-headed Woodpecker

II-Wings marked with numerous cross-bars or spots

$\mathrm{O}$-Under parts spotted, barred, or streaked with black

$\mathrm{X}$-Back golden brown, black crescent on breast, underwings yellow, rump white

Flicker

$\mathrm{XX}$-Back entirely black; male with yellow crown

Arctic Three-toed Woodpecker

$\mathrm{XXX}-$ Back black and white

$\mathrm{Y}$-Breast with broad black band, nape red Yellow-bellied Sapsucker, female

YY-Breast white, male with yellow crown American Three-toed Woodpecker

OO-Under parts plain

$\mathrm{X}$-Back with white streak down middle; wings barred black and white

Y-About 6 in. long (size of sparrow) Downy Woodpecker

YY-About ro in. long (size of robin) Hairy Woodpecker

$\mathrm{XX}$-Back spotted or cross-barred with black and white, not streaked

$\mathrm{Y}-$ Back of head red; top also in male; male red-bellied

Red-bellied Woodpecker

YY-Top of head and throat red; belly yellow

Yellow-bellied Sapsucker, male 
A-6. The flycatchers: Birds with bill hooked at the tip, with bristles at the base of the bill; best known by their habits. The flycatcher sits on some vantage point to watch for insects; spying one it flies out to get it and then flies back to the same or nearby perch to await the next. Mostly small birds, smaller than robin and many smaller than a sparrow

E-Belly bright sulphur yellow

I-Crested; 9 in.

II-No crest; $5 \frac{1}{2}$ in.

Crested Flycatcher

Yellow-bellied Flycatcher

$\mathrm{EE}-$-Belly not bright yellow, may be washed with pale yellow

I-Tail black, conspicuously tipped with white

Kingbird

II-Tail without white

$\mathrm{O}$-Upper parts very dark, wings much longer than tail

X-A tuft of fluffy yellow-white feathers on each flank

Olive-sided Flycatcher

$\mathrm{XX}$ - No tuft of feathers on flank

Wood Pewee

OO-Upper parts not very dark; wings scarcely longer than tail

$\mathrm{X}-$ Bill all black; wing bars indistinct; tail

twitches; pure white on under parts

Phoebe

$\mathrm{XX}-$ Bill not all black; wing bars distinct; under parts yellowish

$\mathrm{Y}$-Lower mandible yellow; says

"chebec" constantly

Least Flycatcher

YY-Lower mandible white or flesh color $a$-Upper parts brown

0 -Wing bars yellow-white

oo-Wing bars brown-ashy

$a a$-Upper parts olive green; wing

bars very conspicuous

Triall's Flycatcher

Alder Flycatcher

Acadian Flycatcher

A-7. Birds with blue conspicuous in their coloring (in some the color is gray-blue)

E-With crest, as large as robin, conspicuously blue,

black, and white

Blue Jay

EE-Without crest

I-Almost entire bird blue

$\mathrm{O}$-Indigo blue, wings and tail dark

Indigo Bunting, male

OO-Blue-black, shoulders chestnut

II-Only parts of bird blue

$\mathrm{O}$-Back blue

$\mathrm{X}-$ Breast red

$\mathrm{Y}$-Broad white line over eye

Red-breasted Nuthatch 
YY - No line over eye

Bluebird

$\mathrm{XX}$-Breast white

Y-Throat black

Black-throated Blue Warbler

YY-Throat white

$a$-Blue band across throat

Cerulean Warbler

$a a$-No band on the throat

$o$-With white wing bars White-breasted Nuthatch

oo-No wing bars

Blue-gray Gnat Catcher

$\mathrm{XXX}$ - Breast yellow, with reddish band

Parula Warbler

$\mathrm{OO}-\mathrm{Head}$ blue, belly yellow

$\mathrm{X}$-White eye ring; breast unmarked Connecticut Warbler

XX-No eye ring; breast with black patch Mourning Warbler

OOO-Head blue, belly and ears white

Blue-headed Vireo

A-8. Birds conspicuously marked with red

E-Bird red all over

I-Body color bright

$\mathrm{O}-$ Color cardinal, except for smudge of black about base of bill

Cardinal

$\mathrm{OO}-$ Color rose red

Summer Tanager

II-Body simply suffused with red over another color

$\mathrm{O}-$ Mandibles of bill crossed

Crossbill

OO-Mandibles not crossed

$\mathrm{X}$-With white wing bars

$\mathrm{XX}$-Without white wing bars

$\mathrm{EE}-\mathrm{Bird}$ red in part only

I-Body red

$\mathrm{O}$-Wings and tail black

- OO-Head, wings, and tail black

Scarlet Tanager Orchard Oriole

II-Body not all red

$\mathrm{O}-$ Breast red

$\mathrm{X}$-Back blue

Bluebird

$\mathrm{XX}$-Back yellow, head blue, rump red

XXX-Back and head black

Pine Grosbeak

Purple Finch

XXXX-Back brown

$\mathrm{Y}$-ro in.

YY $-5 \frac{1}{2}$ in., crown, throat, sides chestnut

Rose-breasted Grosbeak

Painted Bunting

Bay-breasted Warbler

OO-Sides red

$\mathrm{X}-$ Head and back black

Towhee

$\mathrm{XX}$-Crown yellow

Chestnut-sided Warbler

$\mathrm{OOO}-$ Red patches on wings

$\mathrm{X}$-Bird otherwise black all over

$\mathrm{XX}-$ Red (orange) also on outer tail feathers;

Red-winged Blackbird upper parts black 
OOOO - Red on throat, bird tiny

Ruby-throated Humming Bird

OOOOO-Red on crown, only showing when crown feathers are erected

Ruby-crowned Kinglet

A-9. Birds conspicuously marked with yellow

$\mathrm{E}$-Head all yellow

I-Most of bird black

Yellow-headed Blackbird

II-Most of bird yellow, possibly greenish yellow

$\mathrm{O}$-Under parts streaked

OO-Under parts not streaked

EE-Head not all yellow

I-Under parts yellow

$\mathrm{O}$-Under parts unmarked with streaks or blotches

$\mathrm{X}$-Whole head dark

$\mathrm{Y}$-Head and back black; the yellow, orange-yellow

Baltimore Oriole

YY-Head slate-colored

$a$-White eye ring

$a a$-No eye ring, throat black

$\mathrm{XX}-$ Head not wholly dark

$\mathrm{Y}$-Head marked with black

$a$-Throat black also

Yellow Warbler

Prothonotary Warbler

a $a$-Throat not black

$o$-Wings and tail black, marked with white

$x$-Crown black, no yellow over eye

Connecticut Warbler

Mourning Warbler

$x x$-Crown yellow, yellow line

American Goldfinch over eye

Blackburnian Warbler, female

oo-Neither wings nor tail black

$x$-Crown black

$y$-Crown only black spot

$y y$-Other black besides

Wilson's Warbler crown

z-Black line down side of neck; yellow line over eye Kentucky Warbler $z z$-No black on neck; white line over eye

Yellow-breasted Chat

$x x$-Crown not black, cheeks black

Maryland Yellowthroat

YY-Head not marked with black

$a$-With two wing bars

o-Green-yellow patch middle

of back

Parula Warbler, female 


\section{BIRD-STUDY}

oo-No green-yellow patch mid-

dle of back

$x$-White spots outer edges

$$
\text { of tail }
$$

Blue-winged Warbler

$x x$-No white spots on tail

$y$-No eye ring

Pine Warbler

$y y$-With eye ring

$z$-Eye ring white

Bell's Vireo

$z z$-Eye ring yellow

t-Throat and

breast bright

yellow, rump

gray Yellow-throated Vireo

廿-Throat and

breast green-

ish yellow;

rump olive

green

White-eyed Vireo

$a$-Without wing bars

o-No spots on tail

$x-A$ white line over the

eye

$x x$-No line over eye

Philadelphia Vireo

Nashville Warbler

oo-White spots on outer tips of tail

Hooded Warbler, female

OO-Under parts marked with spots or streaks

$\mathrm{X}$-Whole throat black, crown black and

sides of neck

Hooded Warbler, male

$\mathrm{XX}$ - Throat or breast marked by a single

large black spot or blotch

$\mathrm{Y}$-Spot crescentic, bird as large as a robin

Meadow Lark

YY-Spot a blotch, bird smaller than a robin

$a$-In addition a black comma running from bill back under eye; horns

Horned Lark

a $a$-A yellow line running back from bill past eye

Dickcissel

XXX-Throat or breast yellow marked by a necklace of black spots

$\mathrm{Y}$-With wing bars and a yellow spot on wing

Magnolia Warbler

YY - No wing bars, no yellow spot on the wings

Canadian Warbler 
XXXX - Throat and breast yellow crossed by chestnut band which continues down each side

Chestnut-sided Warbler

XXXXX - Throat and breast yellow, marked by dots or streaks of darker color

$\mathrm{Y}$-Crown yellow or orange

$a$-Back black, head black and orange

Blackburnian Warbler

$a a-$ Back not black

o-Back greenish yellow, unstreaked

oo-Back yellow, streaked

Yellow Warbler

Bobolink (rice-bird plumage)

YY-Crown dark

$a$-White patch or bars on wing

$o$-White patch on wing, ears chestnut

Cape May Warbler

oo-Two wing bars

$x$-Back greenish with chestnut spots

$x x$-Back greenish yellow, no spots

$a a-$ No white patch or bars on the wings

Prairie Warbler

Pine Warbler

Palm Warbler

II-Under parts not yellow, yellow present only in spots or patches

$\mathrm{O}-$ Nape yellow, wings and tail black

OO-Nape not yellow

$\mathrm{X}-$ Forehead or crown yellow

$\mathrm{Y}$-Wings black

YY-Wings not black

$a$-Shoulders yellow

$o$-Rump also yellow

oo-Rump not yellow

$a a$-Shoulders not yellow

Bobolink

o-Throat black, cheeks yellow

oo-Throat not black

Golden-cheeked Warbler

$x$-Sides chestnut, cheeks white

Evening Grosbeak Sides not chestnut, crown patch bordered by black

Golden-crowned Kinglet

$\mathrm{XX}$-Forehead and crown not yellow, throat

black 
$\mathrm{Y}$-Cheeks yellow

Black-throated Green Warbler YY-Cheeks not yellow, orange-yellow on wings and tail

American Redstart

A-Io. Birds that appear chiefly brown

E-Brown all over

I-Seal brown all over, no markings

Cowbird, female

II-Rusty brown all over, yellow eye

$\mathrm{EE}$-Not all-over brown

I-Upper parts brown and unstreaked, unspotted

$\mathrm{O}-$-Crested

OO-Uncrested; under parts spotted or streaked

$\mathrm{X}$-With wing bars; larger than robin

Cedar Waxwing

Rusty Blackbird, female

$\mathrm{XX}$-Without wing bars

$\mathrm{Y}$-Larger than a robin

$a$-Bill yellow

Yellow-billed Cuckoo

$a a-$ Bill black

Black-billed Cuckoo

YY-Smaller than a robin

a-Tail rufous, brighter than back

$a a$-Tail not brighter than back

o-Crown orange bordered by

black

Brown Thrasher

oo-Crown not orange

Ovenbird

$x$-Back of head much

lighter than back; spots

on breast round, large

Hermit Thrush

$x x$-Back of head not lighter than back

$y$-White line over eye extending back of eye $z$-Throat streaked

Water Thrush zz-Throat not

streaked Louisiana Water Thrush

$y y$-Line, if any, over eye not extending back of eye

z-Upper parts cinnamon brown, no

eye ring Veery or Wilson's Thrush

$z z$-Upper parts olive

†-Eye ring white;

lores gray Gray-cheeked Thrush

$¥$-Eye ring cream

buff, as also

lores

Olive-backed Thrush 
II-Upper parts brown but streaked or spotted, at least tail and wings

$\mathrm{O}$-Bill slender; tail either cocked up or with stiff, bristle-tipped feathers

$\mathrm{X}$-Seen on tree trunks, running up and down clinging to bark

$\mathrm{XX}-$ Not with the foregoing habits

$\mathrm{Y}-$ No line over the eye

Brown Creeper

YY-With a line over the eye

$a$-Tail tipped with grayish white

$a a$-Tail not tipped with white

$o$-Back streaked with white

$x$-Crown streaked Short-billed Marsh Wren

$x x$-Crown not streaked Long-billed Marsh Wren oo-Back not streaked with white $x$-Belly heavily barred

$x x$ - Belly unbarred

Winter Wren

Carolina Wren

ÓO-Bill short, mostly stout; tail neither cocked up nor with stiff bristly tip

$\mathrm{X}$-Birds nearly as large or larger than a robin

$\mathrm{Y}$-With conspicuous bristles around base of bill; bill very small; mouth very large, its gape an inch or two $a$-White spot on wing

$a a-$ No white spot on wing

o-Slightly smaller than robin

oo-Considerably larger than a robin; the song like that of whippoorwill but with an added syllable; song more slowly given

Chuck-will's-Widow

YY - No bristles around bill; bill large and stout; henlike in form, rising from ground with a loud whirr $a-$ ro in. long; throat and line over eye white or light

Bobwhite

$a a-18$ in. long or nearly so, no line over eye

o-Breast and belly white, indistinctly barred; sides plainly barred

Ruffled Grouse

oo-Breast, belly, and sides all evenly barred

Prairie Chicken 
$\mathrm{XX}-$ Birds smaller than robin, not rising with whirr; sparrows and finches

$\mathrm{Y}$-A cream buff band across a white breast

Lincoln's Sparrow

YY - No cream buff band on breast

$a$-Crown olive green

Henslow's Sparrow

$a a$-Crown not olive green

0 -Crown striped (not streaked)

with white

$x$-Throat with white spot under chin

White-throated Sparrow

$x x$-Throat without white spot

$y$-Crown and face striped brown and white; outer tail feathers white

Lark Sparrow

$y y-$ Crown striped black and white

White-crowned Sparrow

oo-Crown black or blackish, possibly faintly striped

$x$-Throat black

$y$-Broad white line from

bill back over eye

Lapland Longspur

$y y$-No white line over eye

Harris' Sparrow $x x$-Throat not black

$y$-Breast black Chestnut-collared Longspur

$y y$-Breast not black

$z$-Orange mark before eye; bend of wing yellow

Grasshopper Sparrow $z z$-No mark before eye; bend of wing not yellow

Leconte's Sparrow

ooo-Crown not black or striped

$x$-Throat black

$y$-Crown red, male with rosy breast

$y y$-Crown gray

$x x$-Throat not black

Redpoll

English Sparrow

$y$-Under parts not

streaked

z-Wing bar black, back very dark

Swamp Sparrow

zz-Wing bars white or gray 
¥-Crown cream buff, a dark band each side

\$-Crown brown $\S$-Forehead black, bill black

\$-Forehead not black I-Black spot middle of breast

2-No spot on breast, bill pink-brown

$y y$-Under parts streaked

$z$-Outer tail feathers conspicuously white

$z z$-Outer tail feathers not conspicuously white

\$-Color bright red-brown above, spots below, the same

\$-Color not bright red-brown $\S$-Spots on breast tend to run together to make one large one at center

$\S \S-$ Spots distinct, no central large one

I-Conspicuous white wing bars, crown streaked

2-No conspicuous white wing bars, crown unstreaked

- $m$-Breast and belly heavily streaked in black

$m m-$ Breast and belly unstreaked, sides streaked

n-Crown gray bordered with black

$n n$-Crown buff bordered with black
Grasshopper Sparrow

Chipping Sparrow

Tree Sparrow

Field Sparrow

Vesper Sparrow

Fox Sparrow

Song Sparrow

Pine Finch

Savannah Sparrow

Grasshopper Sparrow

Leconte's Sparrow 
A-I I. Birds that are conspicuously black or black and white $\mathrm{E}$-Black the dominant color

I-Black all over

$\mathrm{O}$-Large birds I9 in. or more; bristles over nostrils

$\mathrm{X}$-Long pointed feathers on throat; nearly $2 \mathrm{ft}$.

Raven

$\mathrm{XX}$-Short, rounded feathers on throat; I9 in.

Crow

OO-Smaller birds; no bristles over nostrils

$\mathrm{X}$-With bronze purple metallic reflections on head, back, and wings; tail taperpointed

Y-Iridescent bars on back feathers YY - No bars on back feathers

Purple Grackle Bronze Grackle $\mathrm{XX}$-With uniform glossy blue-black plumage; tail square

Rusty Blackbird, male

II-Not black all over

$\mathrm{O}-$ Head and neck seal brown

Cowbird

OO-Head and neck rusty brown, bird gray below

Rusty Blackbird, female

EE-Black not the dominant color

I-Black and white chiefly

$\mathrm{O}-$ Black and white streaked

$\mathrm{X}$-Crown streaked; a creeper on tree trunk and branches Black and White Creeping Warbler XX-Crown solid black

Blackpoll Warbler $\mathrm{Y}-$ Back gray $a$-Wings and tail black; black bar through eye

Shrike $a a$-Black cap and chin

Chickadee

YY-Back blue, throat black Black-throated Blue Warbler II-Black and yellow

$\mathrm{O}-$ Head black except cheeks, which are yellow

OO-Head yellow, throat and breast black

Golden-cheeked Warbler

Black-throated Green Warbler

A-I 2. Birds not included in the foregoing groups

$\mathrm{E}$-Birds nearly as large as or larger than robin

I-All-over slaty gray; a black crown (call a catlike meow, song variable)

Catbird

II-A blue gray and white bird with large head, throat white; seen along streams or pond margins; call a rattling roll

Belted Kingfisher 
III-Slender, dovelike bird, gray in color, call a soft coo

Mourning Dove

EE-Birds no larger than a sparrow

I-Upper parts olive green

$\mathrm{O}-$ White and black line over eye

$\mathrm{OO}-\mathrm{No}$ line over eye

$\mathrm{X}-\mathrm{No}$ wing bars

Red-eyed Vireo

$\mathrm{XX}$-With wing bars

II-Upper parts not olive green, but slaty; breast slaty, belly white, bill horn color; outer tail feathers white 






\section{SEEDS AND SEEDLINGS}

Planting.-Plant in trays in the schoolroom three of each of the following seeds, first cracking the pine seeds and chipping the castor beans: barley, castor bean (six of these), corn, nasturtium, oats, pea, pine, pumpkin, radish, sunflower. Plant at a depth about equal to the greatest diameter of the seed. Firm the soil over the seeds after planting. Mark the position of each kind so that you will know what is coming up when it germinates.

Seedlings.- Rule the opposite pages after the manner of the sample shown below, and keep record on them of the events during growth:

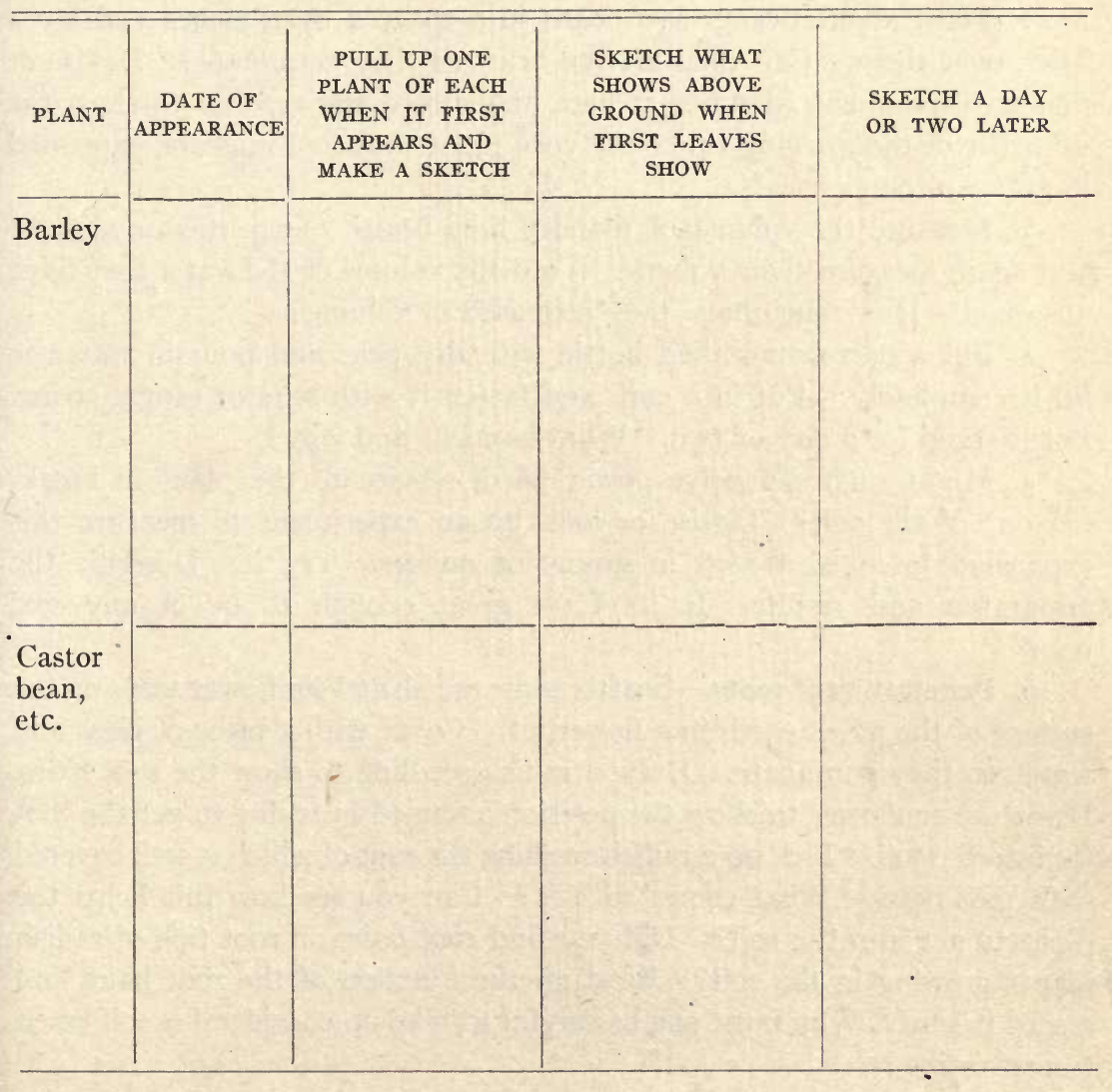


The young plants.-The problems of the young plants are (I) if the seed is on the surface to get into the ground; (2) if the seed is underground to get its stem and leaves out to the air; (3) to break out of its seed coats and get rid of them.

Getting out of the ground.-Review your sketches above and answer the following: Which of these little plants have the same method of getting out of the soil? What mechanical device does the corn use in getting out? Why does not the bean come up in the same way? Can you see any probable reason for the fact that the bean brings up its cotyledons while the pea does not?

I. Stick a long, sharp straw vertically into the top of the part of the bean plant that first appears. Fasten a piece of glass immediately over the upper end of the straw. With a dot of ink mark on the glass the position of this end. Do this every hour or two for a whole day. How is this part of the plant moving?

2. Plant about twenty-five beans in a space 4 by 8 inches and lay a brick over them. Can they lift the brick as they germinate? Devise or find an experiment (describe it here and record the results) to show the upthrust of the growing tip of the corn plant that first appears, expressed in grams or ounces.

3. Measure the volume of five dry lima beans. Soak them overnight and again measure their volume. Find the volume of the water they have absorbed. How much have they increased in volume?

4. Fill a narrow-mouthed bottle with dry peas and pour in water to fill it completely. Put in a cork and fasten it with wire or strong string. Let it stand for a day or two. What happens and why?

5. Might such expansive power be of service to the plant in breaking out of the soil? Devise or look up an experiment to measure this expansive force of a seed in grams or ounces. Try it. Describe the apparatus and results. Is its force great enough to be of any real use?

6. Penetration of roots. - Scatter some radish and sunflower seeds on the surface of the moist earth in a flowerpot. Cover with a piece of glass and watch as they germinate. Draw a radish seedling to show the root hairs. Draw the sunflower to show the position assumed in trying to get the root tip into the soil. Pick up a radish seedling the root of which is well covered with root hairs. What comes with it? Can you see how this helps the plant to get into the soil? Did you find root hairs on root tips of radish plants growing in the soil? Read up the function of the root hairs and record it here. Why must one be careful to take up considerable soil when transplanting? 



The parts of the seedling.- Root up a bean plant on which the characteristic bean leaves begin to appear plainly and sketch it, labeling the following parts: (a) cotyledons, $(b)$ plumule, now expanding into what? (c) stem, $(d)$ taproot, $(e)$ secondary roots.

Soak several lima beans overnight. Open one, remove one cotyledon, and make a diagram to show $(a)$ seed coat, $(b)$ micropyle, $(c)$ chalaza, (d) hilum, $(e)$ cotyledon, $(f)$ hypocotyl (how is it related to the micropyle ?), (g) plumule. What constitutes the embryo?

Study the pine seed, the castor bean, soaked kernels of corn, pumpkin, and pea; diagram each (enlarged) to show the parts. There are two seed coats present in some of these (testa and tegmen). The material packed around the embryo in the corn is called "endosperm." Keep in mind what you have seen in the growing seedlings as you try to interpret what you see in the seed. How does the sunflower plantlet get rid of its seed coats? Describe the method here. See and sketch the special device of the pumpkin plant for tearing off the seed coats.

7. Plant food in seed.-Put a little starch into a test tube, fill the latter one-quarter full of water and shake it. Add a drop of chloride of zinc solution; note the color. This is a characteristic test for starch. Cut the coat from a dry corn kernel and scrape, testing the scrapings with iodine in the same way. State your conclusion.

8. Take the "meat" out of a Brazil nut, cut it in half, stick one-half on a knife blade or hatpin and light the cut surface. How long will it burn? Lay the other half, cut face down, on a piece of paper. These experiments show what? Put a pea on the end of a hatpin and hold in a flame to burn it. Notice the odor. It smells like what?

9. As soon as bean plants are up far enough cut one cotyledon from one, two from the second, and leave the third with both cotyledons on. Keep a record of the rate of growth. Thus:

At the end of ten days No. I is......... inches high and its largest leaf is......... inches long. No. 2 is......... inches high and its largest leaf is.........long. No. 3 is........ inches high and its largest leaf is.......... long.

From these last experiments what do you conclude? State your conclusions. What use does man make of the facts you have just stated?

Read up on the structure of a grain of wheat and diagram it here to show where the chief food substances are located in the grain. Do the same for a kernel of corn.

The process of food manufacture in the plant, after the supply stored in the seed is exhausted, is made plain by the following experiments: 
Io. Fix a cork to the neck of a long-necked bottle or flask. Cut it in half and file out a groove in each half, so as to form a hole that will receive the stem of a plant. Fill the flask nearly full of water. Root out a nasturtium plant or a small geranium with several leaves; wash off the soil from the roots and set it in the flask, the stem held by the cork, the roots in the water. A twig of cottonwood or other tree may serve in place of the small plant. Put it into the water immediately when it is cut off the tree. See that the cork fits tightly and that water cannot escape where the plant stem emerges from the cork. Mark the level of the water in the neck of the flask. Let it stand for several days and mark again. Measure the volume of water that has gone from the flask. Measure roughly in square centimeters the several leaves on the twig or plant. Estimate the number of leaves on a good-sized tree. How much water would it transpire daily? State the results of your estimate.

II. Inclose the pot of a small potted nasturtium, freshly watered, in sheet rubber (dentist's rubber) or paraffined paper, fastening the rubber snugly around the stem of the plant with a cord. Weigh it, rubber and all, at once. Let it stand for several days and weigh again. What does this experiment show that the foregoing one did not? Compare the results with the results of the above. Record.

I2. Mount a strip of the epidermis peeled from the under side of the leaf of Wandering Jew in a drop of water on a slide and cover with a cover glass. Examine under a microscope. Draw to show the stomata. Consult books to find some estimate of the number of them to a square centimeter of leaf surface and give the data here.

I3. See a cross-section of a leaf under the microscope and draw to show upper epidermis, palisade tissue, parenchyma, lower epidermis with its stomata. Make diagrammatic drawing.

I4. Add a teaspoonful of red ink to a half-tumbler of water. Put in it a stalk of celery and a white carnation on a short stem. Let stand for twenty-four hours. What happens? Cut open the celery stalk. This shows two things: (I) that fluids are conducted in the stem along the

(2) that not only water but substances

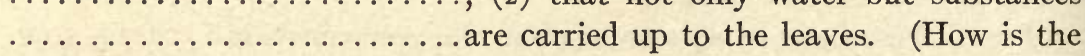
red ink made?)

I5. Take two quart fruit jars. On the bottom of each place a small potted plant and a short piece of candle. Light each candle and screw on the tops. Why does the flame go out? What is there in each jar? Let stand in good sunlight for at least twenty-four hours. Make some limewater (find out how to do it) and test your own breath for carbon dioxide. Pour a couple of teaspoonfuls of limewater into one jar, removing the 




cover as little as possible. Shake it around thoroughly and look to see what its condition is? What does this show?

Light a splinter of wood and slide the cover of the other jar to one side enough to admit it. Does it burn in the jar? This shows what?

I6. Turn over boards or stones in the field to find a plant growing partly under the board, partly out in the light. What is the color of the coveredup portion? What is the usual color of all plant leaves? Do you know why? Take a blanched leaf and a green leaf from the plant you have found. Notch one so you can tell them apart. Put both into 70 per cent alcohol in a small covered dish for a few hours, until the green color is gone from the green leaf. Warm the alcohol if necessary. (Be careful; it burns readily.) Pour off the alcohol, wash with water, and stain with iodine solution. State your conclusion.

Read up now on the process of food manufacture in the plant and write a statement of what occurs in the leaf as sugar, for instance, is made. Refer to the experiments as needed to illustrate the steps. What part does light play in the process? the chlorophyll? Draw on the opposite page a seedling plant to show that it is sensitive to the influence of light; also a "leaf mosaic."

I7. Set a piece of cardboard vertically in a flowerpot. Fill one side of the pot with sand and the other with well-manured earth. Then remove the cardboard partition and plant on the midline between the two sorts of soil a few oat or sunflower seeds. When the seedlings are well up displaying several leaves, root up carefully and see where the roots are.

Roots ordinarily grow........ in response to....... Do you realize how remarkable it is that two points so close together as the stem and root in the embryo should start one up and the other down under identical conditions? The roots in the experiments grow.......... in

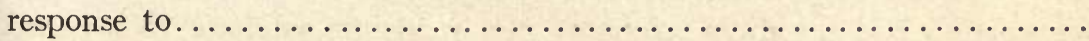
(Does the term you fill in here explain the phenomenon or name it?)

Work.-Does a plant work? If so, where does it get the energy to accomplish it? The partial answer has been given above. This experiment will make clear another source of energy.

I8. Put a layer of moist, crumpled, filter paper or blotting paper in each of two pint fruit jars. Add a level teaspoonful of radish or clover seed. Put in another layer of paper and more seed in each, then moisten and screw on the covers. Let stand three or four days, until the seeds are plainly germinated. Introduce carefully a lighted splinter of wood into one jar, sliding the cover slightly to one side for the purpose. What happens? Try the limewater test for carbon dioxide on the contents of 
the other jar, pouring off the limewater to see if it is milky after shaking it about. What process in your own body is the equivalent of this ?

I9. This same process of $\ldots \ldots \ldots \ldots \ldots \ldots$ is going on in roots. Put a piece of blue litmus paper in a small bottle of water (or fill one partly full of phenol-phthaleine solution to which has been added a drop of dilute ammonia). Root out a small nasturtium or other small plant and set it in the bottle, holding it in place with absorbent cotton packed into the neck around the stem. Let stand for several days, noting changes in color of the paper or solution. Meanwhile dip blue and red litmus paper into dilute acid and dilute alkali, like ammonia, to note effect and to see that litmus is a test for an acid. Try a drop of dilute alkali and of dilute acid in the phenol-phthaleine solution.

Why will plants not thrive as well in crocks or cans as in earthenware pots? How would you build a window box to avoid this difficulty?

20. If you girdle a tree what happens? This shows what? Peel off the bark from a narrow ring at about the middle of a willow or basswood twig. Set this in a bottle of water so the peeled ring is an inch or so above the water. Plug the neck of the bottle with absorbent cotton. Does the twig keep fresh? Evidently the water is going up to the leaves through Let stand for several weeks and see on which side of the ring the new roots grow. This shows what?

$2 \mathrm{x}$. Soils. - The chemical compounds that make up the tissues of plants are chiefly carbon $(C)$, hydrogen $(H)$, oxygen $(\mathrm{O})$, and nitrogen $(\mathrm{N})$, together with relatively small quantities of phosphorus $(\mathrm{P})$, calcium $(\mathrm{Ca})$, sulphur $(\mathrm{S})$, iron $(\mathrm{Fe})$, etc. Which of these have we seen go into the plant from the air? Which from the soil? Which of these several things is of most importance may be judged from this experiment: Take seven pots of clean sand. Mix thoroughly into No. I half as much pulverized sodium nitrate as can be put on a dime; in No. 2 the same amount of sodium phosphate; No. 3 , sodium sulphate; No. 4 , calcium sulphate; No. 5 , iron sulphate; No. 6, mix all these substances in equal amounts and add the same quantity of the mixture; to No. 7 nothing is added. Plant twenty oat or barley kernels in each pot, water carefully with distilled water or rain water, and keep them growing for several weeks. Note the color and general vigor of the plants. Record results and conclusions.

22. Take 500 grams of garden soil and put it in an iron dish that you have previously weighed. Set the pan with the soil on a ring stand over a Bunsen burner that is burning with a flame that will keep the soil warm but not burn it, or the pan may be warmed on the stove. At the end of twenty-four hours let it cool and then weigh it and record the weight. The loss of weight represents what? Put the pan of soil back on the ring stand 




or on the stove and heat it hard for three or four hours, stirring it occasionally with a glass rod. Again cool and weigh. The loss of weight represents what this time? Stir the soil sample into two liters of water. Let it stand for a minute or two until the sand settles to the bottom. Pour off the water and the contained silt into a second vessel. Dry the sand and weigh it. Thus a rough analysis of the soil has been made.

23. Mix a half-tumbler of garden soil with water to the consistency of thick cream. Put a bit of blue litmus paper in it and let stand, noting any change in color of the paper. What does the experiment show?

24. Fill a student-lamp chimney or long, wide glass tube with fine, dry sand, tying a cloth over one end so it cannot spill out; fill another with coarse dry sand, another with dry garden soil, and another with dry pulverized clay. Set all four, cloth end down, in a pan and fasten so that they will not tumble over. Now pour water into the pan. Which sort of soil absorbs water most rapidly? In which does the water finally rise highest? State your conclusions.

25. Fill three low pots of equal size with garden soil. Now pour roo c.c. of water into each. Sprinkle a layer of sand a quarter of an inch deep in one pot, a layer of garden soil in the other, and leave the third without any added soil. Weigh all and record the weights. Let them stand for twenty-four hours and weigh. Weigh again at the end of fortyeight hours. Record the weights and your conclusions from the experiment. 


\section{THE GARDEN}

Garden work is primarily aimed at (a) the formation of a life-habit of productivity, (b) the acquisition of skill in garden activities, with the attendant joy in such work. The desired skills that may readily be achieved in elementary-school work stated approximately in the order of their difficulty are as follows: Raising annuals from seeds planted in the open; raising them from seeds planted indoors, then transplanting to the open; raising perennials from seeds and transplanting to permanent positions; raising flowers from bulbs, such as paper-white narcissus, jonquils, daffodils, tulips, hyacinths, amaryllis, planting these bulbs in pots indoors and in beds outdoors; preparation of soil; cultivation; handling fertilizers; propagation by cuttings, layering; window gardening; raising tree seedlings and grafting; pruning; making and handling the cold frame and hotbed; planting the home grounds with reference to maximum production and beauty of effect.

Annuals. - Obtain a catalogue of flower and vegetable seed from some reliable dealer and with its aid plan a garden and draw to scale for kindergarten and first and second grades, selecting both flowers and vegetables to be planted by each grade. The ones most easily handled are to be planted by the kindergarten, more difficult ones by the first grade, and still more difficult ones by the second grade - all to be things that will mature either before school is out in June or else in the fall and be ready to harvest after September. The garden is to be a community garden to be worked in common under the direction of the teacher instead of having individual plots for the pupils. Space to be occupied 30 by $30 \mathrm{ft}$. Let the class decide on the best plan and put it into operation, members of the class doing the work. If space will not permit the entire garden, try work for only one grade. It is supposed that the ground is fertilized and spaded. Demonstrate the use of hoes and rake, use of stakes and line in making straight rows, making the drills, putting in seed, covering and firming the earth afterward. List the seeds to be used, the depth at which each kind is to be planted and the distance apart in the drills.

Determine what varieties of tomato, cabbage, and asters are best for your climate, then buy these seeds. Find out what is the proper time to plant and then plant in pans indoors the seed of these plants. Transplant some to individual pots for "pot-grown plants" and leave the others in the pans to set out directly in the ground. What is the average date of the last 


killing frost in your locality? When danger from the frost is over set out the plants in the garden.

Perennials.- Prepare a seed bed for perennials. Let each student try to grow one sort. Select the best perennials, including in the list asparagus, rhubarb, hollyhocks, and phlox. Find out what varieties of these as well as of the others are best suited to your locality. Plant seeds of them and in the fall transplant to their permanent locality in the school garden. Mark the spots where they are set so that they will not be disturbed in the spring cultivation.

Bulbs.-Find out how to plant these several sorts of bulbs, both indoors and out, including information regarding time to plant, the depth at which they should be planted, and the distance apart in the bed: paper-white narcissus, jonquil, crocus, daffodil, freesia, Roman hyacinth, hyacinth, amaryllis. Write up this information on the opposite page. Set some of these in pots for indoor blooming and some in beds outdoors.

Preparation of soil, cultivation, and handling fertilizer.-In the work with seeds and seedlings we have studied the principles underlying the preparation of the soil, its cultivation, and the use of fertilizers. For a review answer the following: Why is the soil spaded and raked? How deep would it be wise to spade? Why is the garden hoed? During what sort of weather must it be hoed and raked most? Is it wise to dig paths between the beds or should they be on the level with the beds? Test the garden soil to see if it needs lime. How much should be applied to a square rod?

Fertilization.-Lay out a plot, say, I6 ft. square (or smaller) and fertilize the upper half with a good dressing of manure dug in well in the fall. Lime the right-hand half. Plant the middle half in September with winter vetch and dig this green fertilizer in, in the early spring, at the time spading the whole plot. Plant tomatoes or cabbage on the whole plot and cultivate all with equal care. Weigh the crop from each of the following portions:

I. Manured, but not limed nor green manured.

2. Manured, limed, but not green manured.

3. Manured, not limed, but green manured.

4. Manured, limed, and green manured.

5. Not manured nor limed, but green manured.

6. Not manured, but limed and green manured.

7. Not manured, limed, nor green manured.

8. Not manured nor green manured, but limed.

In a similar way a portion of the school garden can be used as a demonstration plot to try out the value of various commercial fertilizers or methods of cultivation on the chief crops of the locality. 
Propagation.- - Let each pupil learn how to make a cutting and then cut a slip from a geranium plant and plant it in damp sand or root it in water. Try the same with Wandering Jew, petunia, heliotrope, and ivy and plant the window boxes with some of these. (See below.) When the shrubs and trees are pruned use the trimmings to make cuttings and start them indoors in pots so that they will be ready to set out fully leaved in the spring. Find out how to make cuttings of currant, raspberry, blackberry, grape, and of ornamental shrubs. Find out what "layering" is and try it.

Pruning.-Read up on the topic of pruning or, better, watch some skilled nurseryman and draw here a diagram of a fruit tree to show how it should be pruned and also one of an elm. Diagram the proper method of pruning a grapevine and of training it on the trellis. Look up and describe the proper method of pruning currants, raspberries, and blackberries. Prepare to prune shade trees, fruit trees, small fruits, and ornamental shrubs, marking with chalk the places at which the branches are to be cut so that the work may be inspected before branches are actually removed. Save the branches removed for cuttings (above) and also for grafting (below).

Get information from books in regard to the proper method of procedure in grafting and budding. Briefly describe it or diagram it here. Practice grafting or budding on some of the branches and twigs obtained from the pruning. Then when some skill is acquired, try it on trees and bushes in the garden. If such are not available or are considered too valuable to chance injury by incompetent workers, try grafting wild pin cherry on black cherry, hawthorn on wild crab, cultivated cherry on the wild, cultivated crabs on wild crab, or seedling tomatoes on pot-grown potatoes indoors.

Window gardens. - The window garden must have good drainage, free access of air to the roots, and an abundant water supply coming to the roots from below. Devise a window box providing these and diagram it here.

Look up in books on window gardening a list of the best annuals and perennials to grow in the window box, selecting those that thrive best as well as those that are readily handled by pupils. Fill in the lists on the opposite page, classifying them as annuals and perennials.

Provide each pupil with part of a window box, if possible; if not, have one at least for the class. Plant it with annuals raised from seeds and bulbs or perennials from slips and cuttings, considering character of foliage, time and color of blossoms, so as to insure a box that will be in good taste. Either in portions of the window boxes or in pots plant indoors the seeds of apple, pear, cherry, peach, plum, and quince, so as to have good-sized 




pot-grown seedlings of these to set out in the garden in the spring. A year later these yearling trees may be used for grafting and budding. Grow also ash, elm, hickory, maple, mountain ash, oak, and walnut from seed for shade trees.

Plotting the home grounds.- On the opposite page draw to scale the plan of a lot 75 by 200 with a house 15 by 40 , garage or barn Io by I6, and a vegetable garden. The object in planting is threefold: (I) to make the lot produce as much as possible in the way of garden stuff, fruit, and flowers, (2) to make it as beautiful as possible, and (3) to make the place attractive to the birds so that they may nest on the grounds.

General directions. - Indicate location of shrubs and trees by a circled number, the number inside referring to the name of the variety given in the key to the scheme. These rough circles should be made approximately to scale and should show the size of the tree or shrub when grown.

The following principles should be observed: Group plants around margins so as to leave wide spaces for the lawn. In planting shrubbery use shrubs blossoming at different times of the year so that something will be in bloom all the time. Consider, also, the fall fruits, so that beds of shrubbery will have color in them even after the leaves have fallen. Keep in mind the height to which various shrubs grow. Low shrubs should be used, of course, for borders, higher shrubs for background. In planting against the house consider the color of the blossoms in connection with the color of the house. Thus a crimson rambler growing on a red brick house is, to say the least, inharmonious. Planting effects should be considered primarily from the inside of the house. The views out of the windows are the first consideration, the effect from the street the second. Flowers growing close to a window must harmonize too with the tinting of the interior walls. In planting shrubs and flowering plants either they should be arranged to produce mass effects, i.e., quantities of the same sort of blossom all together at one time, or they should be set so as to have contrasts of foliage and variety in the time of bloom, thus securing a clump that will be bright with flowers or fruits at all seasons.

Native shrubs and trees may be used to plant either the home grounds or the school grounds with very little expense if one is willing to take time to locate specimens that can be transplanted and if one will learn how to do it. In transplanting shrubs or trees take up as much of the root system as possible with a good-sized mass of adherent earth. Have a hole prepared to receive it and set the plant promptly. Spread the roots, then cover with soil, either washing it in or stamping it in. It needs to be packed closely about the finer roots. The head of the tree or shrub should be cut back so that it will be approximately the size of the root system set in the 
ground. Transplanting is best done in the late fall except in the case of the conifers. These are to be transplanted on cloudy and preferably cool days in July or August. Keep the root mass covered with damp sacking while the tree is being transported.

Planting the home grounds.-Before starting the planting it would be well to fill in the tabulation of trees and shrubs that are attractive to the birds and of other desirable ones and also a list of the annual and perennial flowers and vegetables that may possibly be used so as to have for immediate reference data regarding size, time of blossoming, etc. Make headings for the tables on the blank pages following as indicated below:

\section{TREES}

$\begin{array}{ccccc}\text { NAME HEIGHT } & \text { DIAMETER OF } & \text { TIME OF } & \text { CHARACTER OF } & \text { SHEDS } \\ & \text { SPACE NEEDED } & \text { BLOSSOM } & \text { FRUIT } & \text { LEAVES WHEN }\end{array}$

\section{SHRUBS}

$\begin{array}{cccccc}\text { NAME HEIGHT } & \text { DIAMETER } & \text { COLOR OF } & \text { COLOR OF } & \text { TIME OF } & \text { FRUIT } \\ & \text { OF TOP } & \text { FOLIAGE } & \text { BLOSSOM } & \text { BLOSSOM } & \end{array}$

\section{DESIRABLE ANNUALS}

NAME HEIGHT TIME OF COLOR OF DATE OF IN- DATE OF DATE OF OUTBLOSSOM BLOSSOM DOOR PLANTING SETTING OUT DOOR PLANTING

DESIRABLE PEREN NIALS

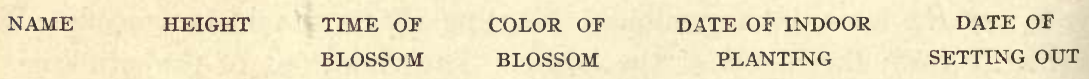
VEGETABLES

NAME

\section{VEGETABLES THAT MAY BE USED FOR A SUCCESSION OR CROPS}

THOSE THÀT MAY BE USED AS

A FIRST CROP AND OFF THE GROUND IN TIME FOR A SECOND

(Alphabetical List)
THOSE TO BE USED AS A SECOND CROP. CHECK THOSE THAT WILL RIPEN IN TIME TO USE GROUND FOR THIRD

(Alphabetical List)
THOSE THAT MAY BE USED AS THIRD CROPS

(Alphabetical List)

Hotbed and cold frame.-The hotbed and cold frame are useful contrivances for starting seeds early and for hardening them preparatory to transplanting. Diagram on the opposite page the construction of the hotbed. If possible construct a hotbed and a cold frame and use them for forcing some of the seeds selected for use in the school garden so that goodsized plants may be had for setting out. 









\section{DAY USE \\ RETURN TO DESK FROM WHICH BORROWED BIOLOGY LIBRARY}

TEL. NO. 642-2532

This book is due on the last date stamped below, or on the date to which renewed.

Renewed books are subject to immediate recall.

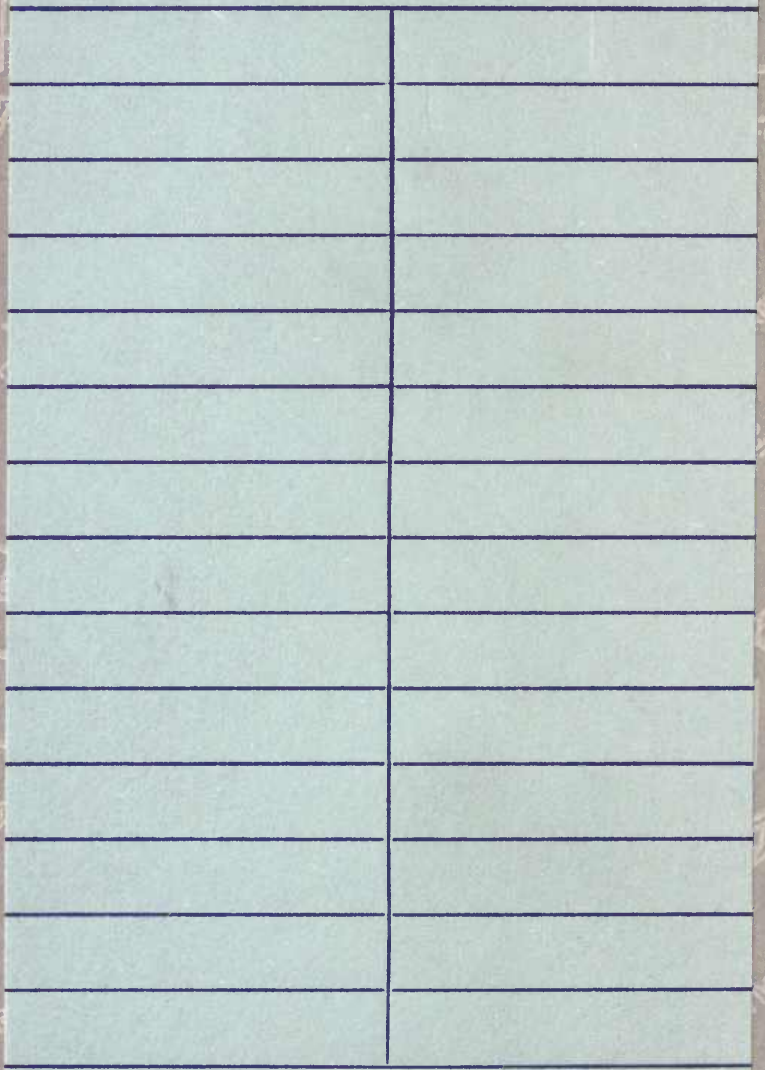

LD21A-6m-1,'75

(\$3364\$10) 476-A-32

General Library

University of California Berkeley 


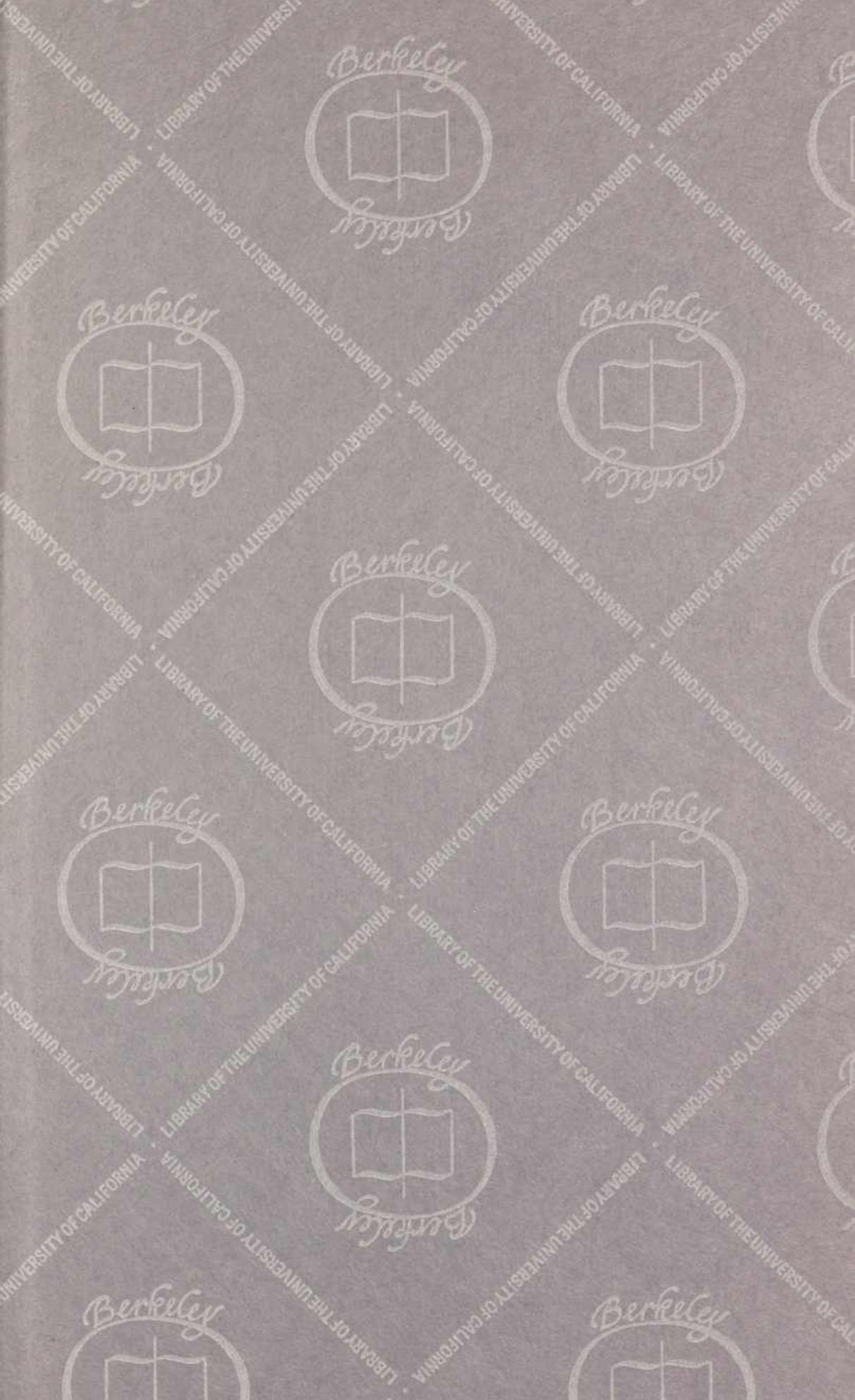


